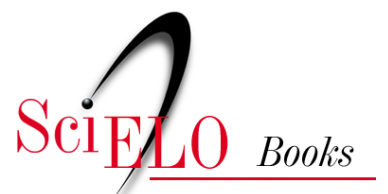

\title{
A saúde persecutória os limites da responsabilidade
}

\author{
Luis David Castiel \\ Carlos Álvarez-Dardet Diaz
}

CASTIEL, L.D., and DIAZ, C.A.D. A saúde persecutória: os limites da responsabilidade [online]. Rio de Janeiro: Editora FIOCRUZ, 2007, 136 p. ISBN 978-85-7541-233-6. https://doi.org/10.7476/9788575412336.

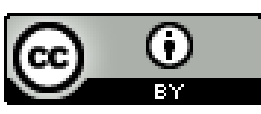

All the contents of this work, except where otherwise noted, is licensed under a Creative Commons Attribution 4.0 International license.

Todo o conteúdo deste trabalho, exceto quando houver ressalva, é publicado sob a licença Creative Commons Atribição 4.0. 
Luis David Gastiei- Carlos Alvarez-Dardet Diaz

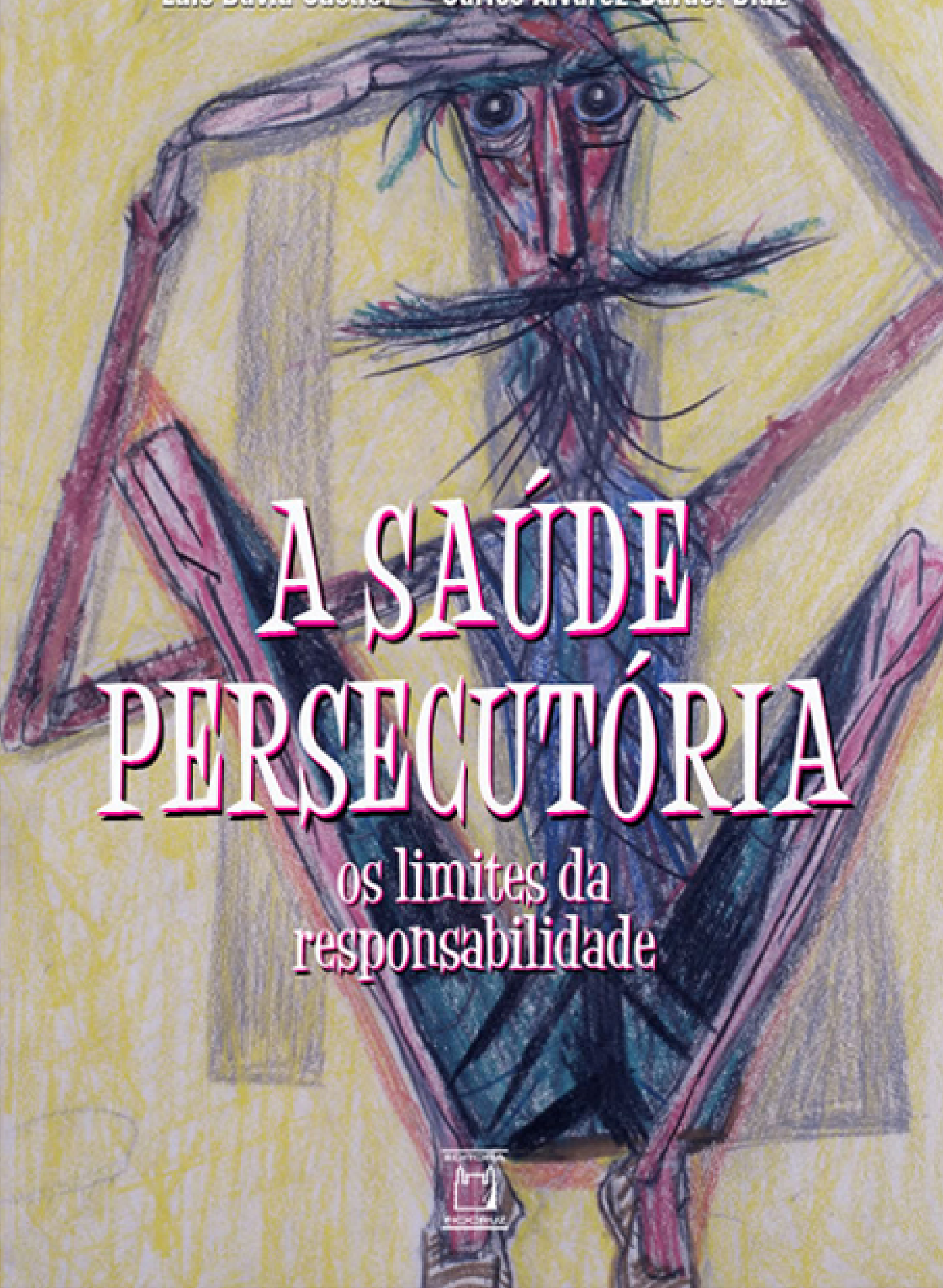




\section{A Saúde Persecutória os limites da responsabilidade}




\section{FUNDAC̣ÃO OSWALDO CRUZ}

Presidente

Paulo Marchiori Buss

Vice-Presidente de Ensino, Informação e Comunicação

Maria do Carmo Leal

\section{EDITORA FIOCRUZ}

\section{Diretora}

Maria do Carmo Leal

Editor Executivo

João Carlos Canossa Pereira Mendes

Editores Científicos

Nísia Trindade Lima e Ricardo Ventura Santos

Conselho Editorial

Carlos E. A. Coimbra Jr.

Gerson Oliveira Penna

Gilberto Hochman

Ligia Vieira da Silva

Maria Cecilia de Souza Minayo

Maria Elizabeth Lopes Moreira

Pedro Lagerblad de Oliveira

Ricardo Lourenço de Oliveira 


\title{
A Saúde Persecutória os limites da responsabilidade
}

\author{
Luis David Castiel \\ Carlos Álvarez-Dardet Diaz
}

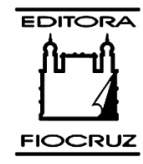


Copyright (C) 2007 dos autores

Todos os direitos desta edição reservados à FUNDAÇÃO OSWALDO CRUZ/EDITORA ISBN: 978-85-7541-129-2

Capa, projeto gráfico e editoração eletrônica

Adriana Carvalho e Carlos Fernando Reis

Imagem da capa

Dom Quixote de Cócoras com Idéias Delirantes [1956], de Candido Portinari.

Desenho a lápis de cor/papel, $37 \times 24,5 \mathrm{~cm}$. Imagem do acervo do Projeto Portinari.

Reprodução autorizada.

Nossos agradecimentos a João Candido Portinari pela cessão de direitos de uso da imagem na capa deste livro.

Supervisão editorial

Janaina de Souza Silva

Revisão

Fernanda Veneu

Catalogação-na-fonte

Centro de Informação Científica e Tecnológica

Biblioteca da Escola Nacional de Saúde Pública Sergio Arouca

C351s Castiel, Luis David

A saúde persecutória: os limites da responsabilidade. / Luis David Castiel e Carlos Álvarez-Dardet Diaz. - Rio de Janeiro : Editora FIOCRUZ, 2007.

$136 \mathrm{p}$.

1.Gestão em saúde. 2.Promoção da saúde. 3.Responsabilidade legal. 4.Responsabilidade social. I.Álvarez-Dardet, Carlos. II.Título.

CDD - 20.ed. - 362.1068

2007

Editora Fiocruz

Av. Brasil, 4036 - $1^{\circ}$ andar - sala 112 - Manguinhos

21041-361 - Rio de Janeiro - RJ

Tel.: (21) 3882-9039 e 3882-9041

Telefax: (21) 3882-9006

e-mail: editora@fiocruz.br

http://www.fiocruz.br/editora

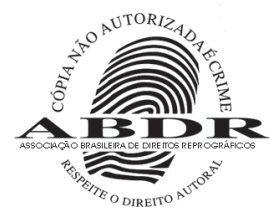


A Carolina, Marcia e San Blas 



\section{SUMÁRIO}

\section{Apresentação, 9}

Introdução: D. Quixotech em Nova Laputa, 13

Parte I - Os Informes Majoritários, a Nova Saúde Pública e a Gestão Saudável de Comportamentos

1 O Informe Minoritário e a Prevenção do Crime Baseada em Vidências, 21

2 Discursos sobre Riscos e Comportamentos Sadios Baseados em Evidências, 25

3 (Pré)culpa, Responsabilidade Individual e Regulação Moral, 35

4 'Errar É Humano, mas Lançar a Culpa nos Outros É Mais Humano Ainda', 43

5 Crentes, Descrentes, Famintos e a Promoção de Saúde Alimentar, 49

6 Vigiar(-se) e Prevenir(-se): a saúde persecutória, 55

Parte II - Estilo de Vida, Genômica e Responsabilidade Individual em Saúde

7 Um Exercício de Sensibilidade Epistemológica, 69

8 A Promoção de Estilos de Vida Saudável, 73

9 Breve Incursão ao Estilo de Vida na Internet e na Academia, 77

10 Estilos de Vida: individual e coletivo, 83

11 Genômica, Epidemiologia e Saúde Pública, 93

12 Genes e Comportamentos em Saúde: em busca de informes responsáveis, 99

13 Os Riscos da Responsabilização Individual na Genomização Epidemiológica, 109

Anotações Finais: a responsabilidade diante dos limites da vida, 121 Referências, 127 



\section{APRESENTAÇÃO}

Cada livro tem a sua história para além do que está escrito. Isto vale também para os trabalhos acadêmicos. Muitas vezes, essas narrativas paralelas não são mencionadas, talvez por serem consideradas algo supérfluo aos discursos objetivantes que predominam nos ambientes da produção universitária. Apesar disso, cremos que vale a pena oferecer ao leitor um pouco do contexto 'histórico', bem como dar alguns detalhes sobre a concepção deste texto.

Este estudo provém de um trabalho em colaboração iniciado em 2000, através de trocas de correspondência eletrônica sobre temas profissionais entre os autores. As afinidades foram aos poucos se definindo. Ambos pertencem à mesma geração, são investigadores em saúde pública, com incursões no terreno da editoria de revistas científicas e com uma postura crítica bem definida no campo sanitário.

Luis David Castiel vive e trabalha no Rio de Janeiro, Brasil (Escola Nacional de Saúde Pública Sergio Arouca da Fundação Oswaldo Cruz), atuando nos Cadernos de Saúde Pública, e Carlos Álvarez-Dardet Diaz na Universidade de Alicante, Espanha (Departamento de Salud Pública) e está trabalhando, até final de 2007, como editor do Journal of Epidemiology $\mathcal{E}$ Community Health.

Os contatos desembocaram em uma proposta de trabalho de publicar artigos e um livro conjuntamente. Diante de um gentil convite e após usuais peripécias e resolução das inefáveis e múltiplas exigências burocráticas, Luis David Castiel se deslocou para a Espanha para um estágio pós-doutoral, com apoio da Capes, no período 2004-2005.

Justamente no decorrer da segunda metade deste período ocorreu o aniversário do quarto centenário de uma das obras-primas da literatura universal, Don Quixote de la Mancha, de Miguel de Cervantes. Várias comemorações foram realizadas na Espanha. Coincidência ou não, alguns aspectos desenvolvidos na presente obra podem induzir o leitor a interpretações que sugiram supostas afinidades com as 'visões' de mundo delirantes do Cavaleiro da Triste Figura. Os autores esclarecem que, caso esta impressão se apresente, tal se passou inadvertidamente às intenções por ocasião da elaboração do livro - mera coincidência...

Mas, diante do resultado, uma vez levada em conta tal possibilidade, acreditamos que ela deva ser assumida, sobretudo sob um ponto de vista crítico-utópico, por razões que, esperamos, deverão ser esclarecidas ao longo do texto. 
Na verdade, o que talvez esteja em jogo seja a possível 'triste figura' que assume a saúde pública hegemônica em seus enunciados atuais ao enfatizar em demasia a responsabilidade individual das pessoas por seus riscos e adoecimentos.

Em termos de definições do estudo, não se trata de algo que se defina metodologicamente a partir de desenhos específicos de investigação. Sua configuração pertence à tradição ensaística crítica, apesar de se ancorar em elementos provenientes de vários setores das ciências da saúde. Enfim, este livro que, também em seu formato autoral, demanda a explicitação dos limites da responsabilidade dos autores. Luis David Castiel encarregou-se do texto e Carlos Álvarez-Dardet Diaz desenvolveu as notas de rodapé, que cumprem um especial papel de comentar, aprofundar e, também, relativizar conteúdos desenvolvidos no corpo do trabalho. No decorrer da tarefa, os autores dimensionaram e assumiram os riscos de possíveis dissonâncias e desarmonias na realização da obra que utiliza formatos não convencionais para apresentar idéias que não são dominantes no campo da saúde. Tanto o texto como as notas foram discutidas e revisadas conjuntamente. No final, para a surpresa dos próprios autores, o resultado pareceu ser mais harmonioso do que poderia ser imaginado, a princípio. Tanto que, aparentemente, se este fato não fosse explicitado, talvez não fosse percebido pelos leitores. Enfim, os autores mesmo com suas concordâncias e discordâncias compartilham a crítica a diversas questões da saúde pública atual.

A primeira parte se inicia com as anotações que situam a perspectiva crítica adotada ao longo do texto e definem o objeto de estudo como próprio aos tempos incertos e inseguros que marcam nossa época hipertecnológica - quase como se estivéssemos vivendo alguma história de ficção científica distópica que poderia ter sido escrito por alguém como Philip K. Dick. Aliás, esta é a idéia desenvolvida na primeira parte: justamente aproveitar-se das idéias contidas no conto "The minority report" (1991) como um exacerbado molde preventivopersecutório que parece constituir-se, apesar do exagero ficcional, no espírito que se manifesta em nossa época em vários domínios, inclusive no campo da promoção da saúde.

Ao mesmo tempo, a biografia do autor mostra como Philip K. Dick foi um exemplo daquilo que desafia os correntes discursos do comportamento saudável - tema da segunda parte. Aí são analisados documentos de organizações supranacionais e nacionais de saúde que sustentam o ponto de vista da responsabilidade pessoal como referência central ao estilo de vida saudável. Daí decorre a questão discutida: as formas modernas de regulação moral mediante novas estratégias de culpabilização socialmente instituídas.

A seguir, utilizam-se exemplos provenientes de aspectos alimentares e nutricionais para ilustrar determinadas dimensões representativas dos sistemas e discursos de promoção da saúde. $O$ final desta parte discute como a linguagem do risco participa ativamente na construção do espírito preventivo-persecutório na saúde, mediante práticas biopolíticas que desembocam na construção do homem responsável por sua saúde e, conseqüentemente, por sua longevidade. 
Na segunda parte, os autores enfocam mais especificamente duas matrizes, uma conceitual e a outra disciplinar - estilo de vida e genômica - como fontes de atribuição de responsabilidade no âmbito da promoção da saúde. Primeiramente, a partir da noção de sensibilidade, empregada em epidemiologia, sugere-se um dispositivo metafórico - a 'sensibilidade epistemológica' - para, em nome de uma suposta 'verificação' da adequação de um conceito/noção/categoria/disciplina, descrever ou explicar aquilo que se pretende conhecer, problematizar a imparcialidade de suas propostas. Isto se aplica ao estudo da noção de 'estilo de vida'.

Nos demais capítulos, faz-se uma breve incursão em vários aspectos da noção de estilo de vida saudável, na internet e na academia. E também aborda-se a importante distinção das respectivas dimensões individual e coletiva vinculadas à noção. As relações entre genômica, saúde pública e epidemiologia são discutidas, sobretudo sob a ênfase das intrincadas interações entre genes e comportamentos e da aproximação entre epidemiologia e genômica, desembocando numa tentativa de teorizar acerca dos riscos de uma progressiva genomização epidemiológica.

No desfecho, propõe-se, entre as muitas tarefas que se apresentam em saúde pública, uma que não deve ser negligenciada em meio às indiscutíveis prioridades de intervenção para evitar ameaças à sobrevivência humana e a seu bem-estar. Esta seria a de questionar, ainda que nos limites da responsabilidade, o alcance de concepções e teorias que nos impeçam de cogitar em outras perspectivas capazes de superar entendimentos teóricos precários das sociedades e dos indivíduos e intervenções insatisfatórias dos processos saúde/doença/cuidado/prevenção.

Agradecimentos aos amigos e colegas do Departamento de Epidemiologia e Métodos Quantitativos em Saúde, Escola Nacional de Saúde Pública Sergio Arouca da Fundação Oswaldo Cruz (Ensp/Fiocruz). Muito obrigado também a Fernando Pires de Albuquerque, Marcos Bagrichevsky, Evandro da Silva Freire Coutinho, Maria Cristina Rodrigues Guilam, João Carlos Canossa Mendes, Paulo Roberto Vasconcellos-Silva e Fernanda Veneu (pela sensibilidade na arte da revisão).

Muchas gracias a los compañeros del Departamento de Enfermería Comunitaria, Medicina Preventiva y Salud Publica e Historia de la Ciencia de la Universidad de Alicante, España y a los amigos y amigas de Madrid, Alicante y San Juan. 



\section{INTRODUÇÃO}

\section{Quixotech em Nova Laputa*}

Há um lugar que, contrariando as leis da física, paira como uma ilha aérea no Pacífico Norte, por levitação magnética. Esse lugar se chama Nova Laputa.

A etimologia da palavra Laputa é controversa: viria do laputano arcaico com o sentido de laap - cabeça, ut - dentro, aah - direto. Há lingüistas que interpretam tal nome como aquilo que existe fora e entra diretamente para o pensamento sob a forma de microentidades que podem se juntar de formas diferentes e se transformar naquilo que hoje se chama 'idéias'. Outros consideram diferentemente: o que está dentro da cabeça serve para representar e entender o que está fora. As discussões permanecem inconclusivas até hoje.

As pessoas que vivem em Nova Laputa são muito bem-educadas, treinadas no interior do melhor espírito racional para orientar suas ações. Existem pesquisadores de diversos tipos que se dedicam exclusivamente a atividades que visam a produzir categorias, classificações, modelos e técnicas para levar a cabo investigações cada vez mais elaboradas e produtivas, de tal modo que conduzam a achados e evidências relativos às causas e razões pelas quais as coisas acontecem da forma como acontecem, e, assim, viabilizem intervenções e a produção de tecnologias que possam colaborar para o bem-estar e para a longevidade de seus habitantes.

As preocupações predominantes na atualidade são diferentes das registradas na Antiga Laputa, em que suas prioridades eram relacionadas à ciência teórica, mormente matemática, astronomia e tecnologia, mas afastadas do campo prático - como construir casas e confeccionar roupas - aliás, essas eram fraquezas dos antigos laputanos. Não existiam fitas métricas, mas somente compassos e esquadros para medir. Assim, casas e roupas fabricadas desta maneira eram muito mal feitas.

Agora, em Nova Laputa, os interesses se voltam principalmente para a pesquisa científica dirigida ao terreno da produção de tecnologias para facilitar a vida e trazer distração para sua gente. Mas não só. Os habitantes de Nova Laputa também buscam melhorias constantes para a saúde de sua população. Uma de suas atividades essenciais é produzir medicamentos

* Uma versão abreviada deste texto foi publicada no Journal of Epidemiology and Community Health - Castiel \& Vasconcellos-Silva, 2007 (N. E.). 
e ações eficazes na busca da elevação da qualidade juntamente com a ampliação dos anos de vida. Ademais, eles se preocupam em melhorar constantemente a aparência física e minimizar os desconfortos emocionais de muitos.

Também continua sendo discutido o fato de ser plágio ou não de um hino de outro país situado nos trópicos o trecho da letra do hino laputano que diz: "Laputa, és mãe gentil dos filhos de seu solo". Há alguns nacionalistas empedernidos que querem mudar o hino nacional por considerarem que os responsáveis pelo hino, além de plagiadores, tiveram a infelicidade de dar margem a interpretações insultuosas ao caráter dos filhos de Laputa.

Abaixo de Nova Laputa há outra ilha maior no nível do mar, antigamente chamada Balnibarbi, agora chamada Balnibarbie (capital Lagado). Lá estavam os indivíduos que trabalhavam para sua subsistência em seus territórios, mas também participavam na sustentação do alto consumo de energia da ilha superior. Caso não se comportassem de modo esperado, sofriam terríveis represálias, incluindo alterações climáticas.

Grande parte do território para além de Balnibarbie foi dominada por Nova Laputa através de um sofisticado sistema de comunicação via rede de máquinas engenhosas - que foram chamadas, em suas versões portáteis mais comuns, de 'laputops', em homenagem ao lugar onde foram concebidas e desenvolvidas.

Através deste sistema de comunicação em rede dessas máquinas, conseguiu-se criar um potente sistema de trocas econômicas em escala planetária em alta velocidade - um fenômeno que ficou conhecido por 'planetarização' e que ampliou o domínio laputano.

Assim, populações de outras regiões do mundo foram submetidas a esta lógica e, por serem consideradas menos civilizadas, passaram a ser chamadas balnibárbaros. Depois de atos de insubordinação que incluíam a prática de atos extremos de violência, Lagado sofreu com vários tsunamis, terremotos e furacões e outros fenômenos de aquecimento local provocados pelos governantes de Nova Laputa que controlavam a luz do sol que chegava aí. Com as mudanças climáticas, a população da cidade a abandonou, e a área se transformou em uma região fantasma que, conforme as marés, some debaixo das águas, passando a se chamar Alagado.

\section{$\diamond \diamond \diamond$}

Existe, em Nova Laputa, um grupo extremista que se denomina Movimento de Libertação do Humano Oprimido no Interior do Acadêmico - ou simplesmente Molhonia. Seu lema é "permita que o ser humano dentro de cada pesquisador saia do armário". São ativistas radicais que criticam de forma contundente as instituições neolaputanas e fazem incômodas chacotas aos intelectuais da ilha ao utilizarem designações como: Organização de Pesquisadores Quixotécnicos, Associação de Bibliotecários da Babilônia, União dos Analistas Idiomáticos Wilkinsianos.

Na realidade, a crítica se dirige a grupos de investigadores, bibliotecários e lingüistas que defendem um exacerbado enfoque teo-empiricista para orientar suas ações. Seguem uma 
religião que se mistura com a atividade acadêmica. Seus textos sagrados consistem em uma coleção de livros religiosos que não cessam de ser escritos, publicados e armazenados em dispositivos portáteis de memória - recebem o nome de 'A Bibliografia Sagrada'. Estes acadêmicos se dedicam com afinco a desenvolver projetos de pesquisas e a publicar compulsivamente os resultados de suas investigações sob a forma de artigos em múltiplas revistas científicas, especialmente aquelas de pedigree acadêmico mais conceituado. Os que mais publicam e mais são citados estão mais próximos de seus deuses e, portanto, protegidos e respeitados. Em Nova Laputa, aqueles que não publicam se prejudicam - isto é, padecem de uma profusão de agruras. Inclusive com alto risco de perecer de maneira precoce, de modo inesperado e sem causas aparentes, como se fora uma maldição lançada por seus deuses bibliométricos.

Para o Molhonia, a perspectiva científica neolaputana é 'quixotécnica' em função de reproduzir o comportamento obsessivamente insano de um personagem inspirado no Quixote escrito identicamente ao de Cervantes, palavra por palavra, mas trazendo uma nova e rica perspectiva, adaptada aos tempos atuais e superior ao Quixote cervantino. Encarnando o atual esvaziamento das narrativas utópicas, D. Quixotech, o Cavaleiro da Entusiástica Figura, se entusiasma com o poder e vigor de seus instrumentos de conhecimento e produção de realidades. Um modelo para uma legião de pesquisadores empiricistas espalhados em rede pelo mundo defendendo, de uma forma ou de outra, os interesses neolaputanos.

Dizem mais: que de tanto lerem manuais de metodologia científica e de estatística, os pesquisadores chegam à conclusão de deter um dispositivo poderoso e efetivo não só para atuar no mundo, mas também para legitimar pontos de vista como sendo superiores e desqualificar outros saberes como sendo insatisfatórios ou pobres para o que importa, ou seja, a produção de evidências via pesquisas empíricas.

Mas este modo de ordenar sustenta, às vezes, inconscientemente, ideologias hegemônicas, de acordo com interesses do poderoso império. Suas 'armas' são as tecnologias de informação e comunicação e objetos técnicos que fazem com que imagens virtuais/representações se confundam com o que pertenceria à suposta ordem do 'real'.

Um dos sintomas da época de Nova Laputa é a dificuldade de distinguir o que seria 'real' e o que seria 'simulacro' ou delírio. O computador constrói realidades virtuais. Há uma implosão das categorias real/virtual que traz dificuldades entre se definir o que 'é' com o que 'parece ser'. Os quixotécnicos laputanos não hesitam em considerar reais objetos que não trazem garantias de sua condição realista. Ou ainda em cair na 'falácia metonímica' que vigora em tempos de rápidas decisões - tomar a parte como representante fidedigno do todo. Ou pior: acreditar que a parte é o todo.

É sabido que a linguagem alegórica veicula idéias e pensamentos de forma figurada, com o objetivo de significar alguma coisa implícita, além do que está sendo explicitado. Já a paródia, seguindo o Houaiss (2004), diz tratar-se de obra literária, teatral, musical etc. que imita outra obra com objetivo jocoso ou satírico. 
Agora, seguindo Agamben (2005), a paródia séria seria algo aparentemente contraditório - mas, na verdade, situa-se na tensão entre formato cômico e o conteúdo sério. O paródico seria algo fora de lugar. Se a literatura pode ser ficcional ou não-ficcional, o objeto da paródia, ainda que deformado, faz menção a algo insuportavelmente presente, por isto, mantido à distância, sob a forma caricatural. A paródia se 'define' na indefinição entre ficção e não-ficção (Agamben, 2005).

O parodiante pode ter razões para renunciar a uma representação direta de seu objeto: o problema de jogar fora o bebê com a água do banho - no presente caso, as dificuldades em simultaneamente admitir o sucesso em vários aspectos do empreendimento científico, no sentido de desenvolver condições técnicas capazes de melhorar as condições de vida de determinados grupos humanos, e ao mesmo tempo criticar seu fracasso em estender seus benefícios a grandes contingentes populacionais deste planeta, ao mesmo tempo que a ideologia cientificista cria a sua premissa de um 'lá-fora' unívoco, impedindo a existência de outras possíveis realidades.

Esta séria paródia alegórica calca-se em várias obras da literatura. Pela inversão de significados, corre o risco de ser mais uma discutível referência, quiçá herética, do que homenagem, às obras dos autores originais. Inspira-se na obra de Cervantes e na parte 3 das viagens de Gulliver - viagem a Laputa, o mundo da ciência de Swift (Swift, 2001). As fontes para quase todas as teorias dos laputanos e balnibarbianos podem ser encontradas nos trabalhos dos cientistas contemporâneos de Swift e particularmente na Philosophical Transactions of the Royal Society nas primeiras décadas de 1700.

É sabido que Swift era um inconformado crítico e satírico da sua época, tendo, sintomaticamente, morrido aos 77 anos, surdo e louco, em 1745, em Dublin, onde nasceu. Em sua lápide, o epitáfio em latim, antecipado por ele, é: "Aqui jaz o corpo de Jonathan Swift, doutor em Teologia e deão desta catedral, onde a colérica indignação não poderá mais dilacerar-lhe o coração. Segue, passante e imita, se puderes, esse que se consumiu até o extremo pela causa da Liberdade" (Wikipedia, Acesso em: 15 dez. 2006).

A paródia também tenta refletir a especial ironia de Jorge Luis Borges em três de seus mais conhecidos contos: A Biblioteca de Babel (1972a), o Idioma Analítico Lingüístico de John Wilkins (Borges, 1999) e Pierre Menard, autor de Quixote (Borges, 1972b). Todos os três autores servem aqui para ilustrar, cada qual a seu modo e em diferentes níveis, o exagerado predomínio da razão instrumental que vigora nos tempos atuais.

O Quixote de Menard (Borges, 1972b) retrata a replicação como essencial ao primado da objetividade; a Biblioteca de Babel (Borges, 1972a) é usada para representar o afã de organização e armazenamento de informação, representado pela grande rede de computadores; e a classificação desconcertante oriunda de uma enciclopédia chinesa presente em "O idioma analítico de John Wilkins”, usada por Foucault (1992) em As Palavras e as Coisas, 
Em suas remotas páginas está escrito que os animais se dividem em (a) pertencentes ao Imperador, (b) embalsamados, (c) amestrados, (d) leitões, (e) sereias, (f) fabulosos, (g) cães soltos, (h) incluídos nesta classificação, (i) que se agitam como loucos, $(\mathrm{j})$ inumeráveis, $(\mathrm{k})$ desenhados com um pincel finíssimo de pelo de camelo, (l) etcétera, (m) que acabam de quebrar o jarro, (n) que de longe parecem moscas. (Foucault, 2002:9)

juntamente com o Quixote, serve como emblema do fim da racionalidade da similitude e início da visão baseada na lógica categorial da identidade e da diferença. Sem dúvida, um ponto essencial para a instituição da racionalidade que veio a vigorar no projeto científico empiricista-positivista.

Este é o pano de fundo para nos situar diante da complexa tarefa de avaliar a real efetividade das propostas individualistas hegemônicas de promoção em saúde centradas em evidências científicas - que aqui recebem o epíteto 'saúde persecutória'. Se Laputa pode ser vista como uma manifestação panóptica (mas, como veremos no livro, não apenas), assim podem ser vistas várias práticas persecutórias da promoção em saúde. Ademais, Jonathan Swift foi contemporâneo do criador do panóptico, Jeremy Bentham.

A idéia de introduzir caricaturalmente o modelo de pesquisa biocientífica dominante na forma aqui apresentada não deveria ser encarada como crítica despropositada, gratuita ou, pior, depreciativa. Ao contrário, trata-se de um convite para um exercício o mais ameno possivel de relativização de posições radicalizadas que podem sustentar configurações ideológicas que conferem superioridade indiscutivel nas propostas de produção de conhecimento que se alicerçam nas fórmulas técnico-instrumentais baseadas no que Law (2004) chama de premissas metafísicas euro-americanas do que há 'lá-fora': em relação à realidade ser considerada como anterior, independente, definível e única.

Propõe-se aqui adotar o 'estranhamento', estratégia sugerida por Ginzburg (2004), como uma forma de problematizar padrões dominantes que se mostram naturalizados, freqüentes, esperados. Estranhar para criticar pontos de vista considerados 'normais' e o conformismo que os acompanha. Para gerar novos olhares, de modo a ensejar novos usos para além da mesmice que se camufla em meio a novidades que proliferam, mas não causam surpresa. É preciso olhar para as coisas que nos rodeiam como se a priori não tivessem qualquer sentido (e que, mesmo com olhares posteriores, continuem a parecer que os sentidos que daí emanam aparentem ser extremamente inconsistentes).

Pode-se explicar, ainda no registro do estranhamento, o motivo pelo qual aparece como ilustração da capa o desenho Dom Quixote de Cócoras com Idéias Delirantes [1956] - desenho a lápis de cor/papel de Candido Portinari. Trata-se de não só chamar a atenção do potencial leitor ao provocar incômodo por meio do talento do pintor, que desenha com crua sensibilidade o Cavaleiro da Triste Figura nesta posição patética em surto delirante. Mas também de acenar para o fato de que Portinari de Brodosqui soube representar com maestria ao Quixote de La Mancha 
mantendo simultaneamente sua universalidade com traços singulares do lado de baixo do Equador. E também trata-se de lembrar que o pintor sofria na ocasião de intoxicação pelas tintas, e, por razões de saúde, foi obrigado por seus médicos a usar lápis de cor. Alguns, ainda, talvez entrevejam alguma parecença caricatural entre a fisionomia de um dos autores deste livro e a imagem deste Quixote. Neste caso, mera casualidade.

O primeiro bloco começa com as anotações que situam a perspectiva crítica adotada ao longo do texto e definem o objeto de estudo como próprio aos tempos incertos e inseguros que marcam nossa época hipertecnológica - quase como se estivéssemos vivendo alguma história de ficção científica distópica que poderia ter sido escrito por alguém como Philip K. Dick. Aliás, esta é a idéia desenvolvida na primeira parte: justamente aproveitar-se das idéias contidas no conto 'The minority report' (1991) como um exacerbado molde preventivopersecutório que parece constituir-se, apesar do exagero ficcional, no espírito que se manifesta em nossa época em vários domínios, inclusive no campo da promoção da saúde. 
Parte I

Os Informes Majoritários, a Nova Saúde Pública e a Gestão Saudável de Comportamentos 



\section{O Informe Minoritário e a Prevenção do Crime Baseada em Vidências}

Partimos de um conto do escritor estadunidense de ficção científica, Philip Kindred Dick, chamado "The minority report". Dick é um nome conhecido na indústria cultural de nossos dias. Em termos cinematográficos, seu nome está associado a filmes hollywoodianos de grande repercussão ou blockbusters. As obras originais possuem títulos fascinantes que, infelizmente, não foram utilizados no cinema por compreensíveis razões mercadológicas. Entre os filmes inspirados em sua literatura, temos Blade Runner - O Caçador de Andróides -, filme de 1982, dirigido por Ridley Scott, a partir do livro Do Androids Dream of Electric Sheep? Os Andróides Sonham com Ovelhas Elétricas? -, publicado em 1969, e que ganhou o prestigioso Prêmio Nebula de literatura de ficção científica daquele ano. E, também, Total Recall O Vingador do Futuro/Desafio total -, filme de 1990, dirigido por Paul Verhoeven baseado no conto de 1966 "We can remember it for you wholesale" - "Podemos recordar para você, por um preço razoável” (〈www.espacioexterior.net/dickdcho.html〉. Acesso em: 1 fev. 2005).

"The minority report" segue a tendência chamada 'distópica' da ficção científica. No caso, descreve novas formas de controle social autoritário e reflete o espírito paranóico próprio de nossos tempos. Foi publicado em 1956 na revista Fantastic Universe e transformado em 2002 em um típico filme de ação hollywoodiano, dirigido por Steven Spielberg. A ação se situa no ano de 2054 em Washington DC, e descreve a atuação de um agente da divisão da polícia pré-crime. Através dos poderes psíquicos de precognição de três humanos alterados geneticamente (precogs), a polícia tenta prevenir crimes antes que estes aconteçam. Os três precogs trabalham em conjunto, ${ }^{1}$ flutuando em um tanque de fluido, ${ }^{2}$ à espera de

${ }^{1}$ Como nos atuais métodos de consenso em torno da prevenção de doenças que proliferam em todos os estamentos e especialidades médicas, os consensos sobre qualquer coisa 'inovaram' a idéia, quiçá demasiado paternalista do comitê de expertos - uma técnica em que se reunem especialistas para estabelecer padrões sobre determinados tópicos de saúde.

${ }^{2} 0$ líquido que sustenta os consensos da evidenciologia não é nada mais do que uma porção da literatura científica, aquela a que se tem acesso pelo banco de dados PubMed, graças a uma iniciativa milionária do governo dos Estados Unidos. 
visões que podem ser convertidas em imagens de vídeo nas quais aparecerão os nomes da vítima e do criminoso e o momento de ocorrência do crime a ser cometido. A partir destes dados, os agentes da lei entram em ação preventiva (<www.espacioexterior.net/ dickdcho.html . Acesso em: 1 fev. 2005).

No entanto, há um incontornável problema legal que reflete um dilema moral. Se alguém é preso antes de cometer um suposto crime, qual será sua responsabilidade sobre este 'fato virtual' e a correspondente punição? O projeto pré-crime está ainda em estágio experimental e será votado em um futuro próximo. Se aprovado, as taxas de crime irão cair acentuadamente. Mas não se saberá quantas das pessoas aprisionadas de fato podem ser inocentes. ${ }^{3}$

O personagem principal é um policial do esquadrão pré-crime que perdeu o filho há seis anos e é dependente de drogas. Um dia, ele recebe a informação dos precogs de que ele mesmo irá cometer um crime em menos de 36 horas. Passa a ser perseguido por seus colegas e segue tênues pistas que possam levar a sua inocência. Um dos elementos centrais de sua busca se prende à tentativa de validar a possibilidade de haver um veredito da minoria (minority report). Como as decisões são deliberadas em grupos de três, é possivel que a previsão minoritária de um dos 'juízes' precognitivos seja diferentes das dos demais - a pouco usual humanidade dos precogs se manifestaria justamente pela respectiva capacidade de cometerem erros... (〈www.espacioexterior.net/dickdcho.html〉. Acesso em: 1 fev. 2005).

$O$ filme deixa de explorar em profundidade o filão que nos interessa aqui: como se manifestam, em nossas sociedades modernas, o controle social e o estabelecimento e aplicação de normas, as dimensões morais relativas à culpa, sobretudo no que tange a aspectos de autovigilância. Antes, porém, de desenvolver estes temas, vale a pena conhecer alguns dados biográficos do autor - o que, em si, pode ser um enredo cinematográfico onde é possível perceber que Dick está longe de ser encarado como modelo compatível com a categoria 'estilo de vida saudável'.

Philip K. Dick nasceu em 1928, em Chicago, e foi o único dos gêmeos bivitelinos prematuros que sobreviveu (sua irmã morreu poucas semanas depois do nascimento). Seus pais se separaram quando tinha 5 anos. Quando tinha 12 anos, começou a ler e escrever ficção científica. Em sua adolescência, sofreu freqüentes ataques de asma e tinha acessos de vertigem. Depois de vender suas histórias a importantes revistas do gênero ficção-científica da época, Dick, em 1951, decidiu dedicar-se integralmente à carreira lite-

${ }^{3} 0$ dilema moral não se refere a uma subversão não só do direito penal, que passa da penalização de delitos para constituir-se em ação pública contra pré-delitos, mas também à prática contemporânea da medicina, na qual já se diagnosticam doenças no sentido nosológico e também pré-doenças.

Aqui se subverte o contrato implícito que vinha regendo a relação médico-paciente desde os tempos de Hipócrates: os médicos já não diagnosticam e tratam enfermidades reais de seus pacientes, mas préenfermidades virtuais que podem acontecer nesse determinado paciente ou não. 
rária e produziu várias obras de ficção-científica nos anos 50. Suas tentativas de publicar temas de não-ficção fracassaram.

Além da literatura, a música despertava seu interesse. Trabalhou em uma loja de discos e apresentou programas de música clássica em uma estação de rádio local (Dick, 1996). Vivendo em 1964 em San Francisco, começa a usar LSD. Como muitos outros intelectuais da chamada geração beat, Dick experimentou diversas drogas, inclusive anfetaminas. Nos anos 70 , foi abandonado pela quarta esposa, que levou consigo a filha que tiveram. Nesta fase, passou por um longo período de falta de inspiração. Somente volta a escrever e publicar em 1973, depois de uma tentativa de suicídio e uma temporada em centro de reabilitação. Para a psiquiatria da época, era um esquizofrênico paranóide.

Em meados desta época, Dick dedica-se quase que exclusivamente a descrever várias de suas experiências místicas, o que sugere indicar sua frágil condição emocional, pois, para muitos, pareciam surtos delirantes. Morreu relativamente jovem em 1982, aos 53 anos, de colapso cardíaco, sem poder assistir a Blade Runner, sua primeira adaptação para o cinema. (〈www.philipkdick.com/aa_biography.html〉. Acesso em: 1 fev. 2005).

Dick pertence, sem dúvidas, a uma geração tipicamente representativa de um modo de viver dos meados do século passado. Há controvérsias quanto a seu talento literário. Para alguns, seria tão-somente um escritor de pulp fiction emocionalmente desequilibrado, com vida afetiva terrivelmente instável, dependente de drogas (suas experiências lisérgicas são quase tão notórias quanto as de Timothy Leary) que se dedicava a um gênero considerado 'menor'. Suas histórias às vezes passam a sensação de desvarios delirantes e angustiados quiçá escritos sob o efeito de alucinógenos <www.espacioexterior.net/dickdcho.html>. Acesso em: 1 fev. 2005). Para outros, suas obras representam com talento a urgência e volatilidade dos tempos atuais, podendo ser equiparado a mestres como Kafka, Beckett e Borges (〈www.philipkdick.com/aa_biography.html〉. Acesso em: 1 fev. 2005).

Em suma, um autor controverso. Mas é difícil negar que ele construía seus entedos com maestria para atuarem como encenações alegóricas dos atuais descaminhos humanos. Suas imagens são especialmente poderosas e se combinam com harmonia a narrativas sedutoras. Ademais, defendeu posições antimilitaristas e xenófobas, bem como tinha obsessão com os esquemas de segurança - sem dúvidas temas dos mais candentes e atuais, mais de duas décadas depois de sua morte. 



\section{Discursos sobre Riscos e Comportamentos Sadios Baseados em Evidências}

Os discursos sobre a saúde nunca se referem tão-somente a dimensões da saúde. Se tais discursos significam modos de pensar, escrever, falar sobre a saúde e suas práticas, é preciso situá-los em determinados momentos históricos e saber as razões por que se legitimam ao acompanharem a ordem econômica, política e social onde são gerados, sustentados e replicados e se ajustarem a ela. Discursos sobre a saúde (e, mais especificamente, sobre riscos à saúde) consistem em construções contingentes, de caráter normativo, inapelavelmente vinculadas a outros interesses. ${ }^{4}$ Dependem, explicitamente ou não, de definições sobre o que é ser humano, o tipo de sociedade que se almeja e os modos de atingi-la (Robertson, 2001).

Atualmente, há um visível predomínio de discursos sobre saúde produzidos por um campo que se convencionou chamar 'nova saúde pública' (NSP). A NSP utiliza conceitos e estratégias como promoção e educação em saúde, marketing social, screening diagnóstico, imunização, participação comunitária, políticas públicas de saúde, colaboração intersetorial, ecologia, economia em saúde, entre outras.

A NSP caracterizar-se-ia por sua postura modernista. Isto é, se ancora na crença iluminista da ciência e nos valores da racionalidade e de suas instituições e modos de organização para sustentar sua legitimidade social com vistas à busca de melhores condições de saúde no eterno enfrentamento às ameaças à integridade humana. Em síntese: a idéia de primazia do individualismo, em que agentes racionais exercem suas prerrogativas; um clima de descrédito quanto à autoridade política dos governos; destaque excessivo quanto ao papel do mercado como instância reguladora da economia (Petersen \& Lupton, 1996).

\footnotetext{
4 Faz 40 anos que a saúde pública se preocupa com a sexualidade dos jovens (começou, sintomaticamente, no decorrer dos anos 60, época conhecida pela liberação de costumes), especialmente diante dos efeitos que podem ter as gravidezes em adolescentes e as enfermidades de transmissão sexual. Existem programas baseados em muitas perspectivas e ideologias, mas ninguém, utilizando a informação científica disponível, propôs, em nenhum lugar do mundo, o fomento do lesbianismo como a prática sexual mais que segura - o risco de gravidez entre lésbicas é zero, e a única infecção sexualmente transmissível que se transmite efetivamente pelas relações entre mulheres é a pediculose do púbis. Toda iniciativa de prevenção em saúde pública tem ancoramentos nas crenças daqueles que as propõem.
} 
Sob tal ótica, a nova saúde pública não aprofundaria as relações de poder e se adequaria a proposições compatíveis com o projeto neoliberal em voga. Ao mesmo tempo, sob o ponto de vista crítico, seus conceitos, quando transpostos do formato individualista para dimensões coletivas - como no caso de 'empoderamento' e 'estilo de vida' -, teriam a potencialidade de atuar em propostas de mudança social (Carvalho, 2004).

Mas, em sua faceta hegemônica, a saúde promocional escapa do âmbito da medicina, da fisiologia, da epidemiologia. Percorre outros caminhos em que vigoram discursos sobre a moral e os bons costumes. E também é portadora de concepções biopolíticas da subjetividade somática que erige o corpo em sua maleabilidade automanipulável como matriz de identidade (Ortega, 2003).

Essa visão de mundo aparece de modo emblemático em Frankish e colaboradores (1998), que estudaram as relações entre a categoria 'viver ativo' (active living) e os determinantes de saúde como meio de demarcar a postura das pessoas em relação a atividades físicas, de lazer e recreação como componentes de um 'estilo de vida' considerado saudável. Sob esta perspectiva, tais pesquisadores afirmam que o 'viver ativo' sustenta que "participação em atividades (comportamentos)" que "envolvem a pessoa como um todo, corpo, mente e espírito; é parte de uma vida dinâmica, na qual indivíduos e ambientes continuamente se interrelacionam e afetam um ao outro, e é subjetivo em natureza, seu significado relativo a cada pessoa" (Frankish et al., 1998: 289).

Algumas críticas à saúde pública atual (Martínez-González \& Irala, 2005) se mostram pertinentes em certos aspectos do 'diagnóstico' da sua precária efetividade em vários quadros ('fracasso clamoroso', segundo a bombástica retórica dos autores). Isto aparece em dimensões como: obesidade, diabetes, doença cardiovascular, consumo de drogas, doenças transmissiveis, acidentes de tráfico e problemas da transição epidemiológica em países em desenvolvimento que não superaram a carga de doenças transmissíveis. Os autores ensaiam uma reprovação ao 'paradigma dos fatores de risco' por 'culpar sempre a vítima' e por se fechar em um 'viés individualista' (Martínez-González \& Irala, 2005: 657). Infelizmente, o 'tratamento etiológico' se mostra contraditório - tanto culpabilizante como individualista, com afirmações, na melhor das hipóteses, ingênuas e categorias de caráter incomodamente comportamentalista. E, mais grave, brandindo argumentos com matizes autoritários ideologicamente discutíveis.

Menciona-se o fato de os conhecimentos epidemiológicos não haverem sido transformados em políticas de mudança de comportamentos. Em relação à obesidade e ao tabagismo, entre outros problemas, o foco da questão se localiza na débil 'força de vontade' das pessoas, solapada pela força da adicção ou do hábito. Para isto, é preciso educálas para mudar comportamentos de modo a viabilizar o 'autocontrole' para que se faça a prevenção, para não se 'chegar tarde' demais. $\mathrm{O}$ argumento se torna culpabilizante ao enfatizar que se deve facultar dimensões como a "autonomia responsável" (grifo nosso), o "autodomínio de uma personalidade madura” (p. 659). Ora, os que não têm autodomínio passam a ser vistos como "criaturas passivas, 
preguiçosas e conformistas" (p. 659), destituídos de capacidade de realizar esforços, diante dos estímulos de contextos culturais inevitavelmente dominados por poderosas indústrias e empresas de comunicação. A leitura individualista se manifesta nitidamente no trecho a seguir: "propor aos cidadãos modelo que thes ajudem a autoconstruir sua personalidade e seus valores, que os façam responsáveis e donos de si mesmos, capazes de resistir às pressões comerciais dos estilos de vida autodestrutivos" (Martínez-González \& Irala, 2005: 659).

Apesar do freqüente uso individualista da noção de 'estilo de vida', a própria Organização Mundial da Saúde (OMS, 1998) atualiza e modifica sua definição admitindo que o 'estilo de vida' se constitui em um modo de viver baseado em padrões identificáveis de comportamento determinados pela interação entre as características pessoais das pessoas, trocas sociais e condições socioeconômicas e ambientais.

A OMS reitera sua importância ao assumir que o estilo de vida tem um profundo efeito na saúde dos indivíduos. Sinaliza também que, se a saúde deve ser aperfeiçoada ao capacitar indivíduos a modificar seus estilos de vida, a ação precisa ser dirigida não apenas ao indivíduo, mas também às condições sociais e de vida que interagem para produzir e manter estes padrões de comportamento. A OMS reconhece, ainda, que não há um 'ótimo' estilo de vida a ser prescrito para todos (OMS, 1998).

O documento, por suas próprias características de glossário, não avança para além do caráter genérico de suas bem intencionadas afirmações em termos da aplicação de suas propostas em termos de políticas públicas. Porém, em outro verbete, enfatiza a dimensão individual das aptidões de vida (life skills) que devem ser ensinadas aos indivíduos durante a fase escolar com vistas a proporcionarem comportamentos adaptativos e positivos que permitam aos indivíduos lidarem efetivamente com as demandas e desafios da vida cotidiana (OMS, 1998).

Nesta perspectiva, tais aptidões pessoais, interpessoais, cognitivas e físicas servem para viabilizar os indivíduos a controlarem e dirigirem suas vidas e desenvolverem a capacidade de conviver e produzir mudanças em seu meio ambiente. Exemplos de aptidões individuais de vida: tomada de decisões e solução de problemas, raciocínio criativo e crítico, consciência de si (self awareness) e empatia, aptidões de comunicação e relações interpessoais, enfrentamento (coping) de emoções e gestão de estresse. Ou seja, traços constitutivos da vida cotidiana no ambiente do individualismo contemporâneo, em que a idéia de responsabilidade pessoal se destaca, juntamente às de liberdade de escolha, direito de decisão, capacidade de agência (agency). ${ }^{5}$ Mas todos estes fatores tendem a ser subsumidos à égide da noção do que podemos denominar competência consumidora.

\footnotetext{
${ }^{5}$ Não seria justo não reconhecer que os movimentos da Nova Saúde Pública e da Promoção da Saúde têm também interessantes exemplos de informes minoritários. A corrente da promoção da saúde hegemônica nos Estados Unidos, centrada na culpabilização das pessoas por suas condutas individuais, não se tornou hegemônica nem no Canadá, nem na Europa, donde partiram as idéias de desenvolvimento de Entornos Saudáveis como tarefa coletiva durante os anos 80 do século XX.
} 
O discurso da responsabilidade é abordado no longo documento com vistas ao estabelecimento de políticas públicas governamentais elaboradas pela unidade estratégica do gabinete do primeiro-ministro da Inglaterra intitulado "Personal responsibility and changing behaviour: the state of knowledge and its implications for public policy" (Halpern et al., 2004). Mesmo assumindo não se tratar (ainda) da configuração de política pública, reflete o espírito vigente no contexto da comunidade européia, em geral, e da Grã-Bretanha, em particular. Vale a pena nos determos um pouco mais neste material, pois parece bastante representativo quanto ao possível rumo que os governos consideram como caminho a seguir diante de aspectos referentes à responsabilidade governamental (sob a forma de políticas públicas) e à responsabilidade pessoal (diante dos comportamentos individuais em termos de saúde), entre outros tópicos.

Segundo o texto, se o povo demanda dos seus governos uma economia forte, melhores condições de educação, segurança, saúde etc., para alcançar isto, os governantes devem utilizar expedientes como leis, punições, regulações, taxações e subsídios, provisão de serviços, informação e persuasão. Muitos destes recursos são desenhados para influenciar mudanças no comportamento das pessoas, em especial aumentando a responsabilidade pessoal e propiciando mudanças comportamentais em áreas como a saúde.

Afirma-se, ainda, no documento que quase todas as políticas públicas se baseiam em premissas sobre o comportamento humano, mas estas, no entanto, raramente são explicitadas ou testadas diante de evidências. O documento teria, então, entre outras, a função de agregar o conhecimento disponível para estimular pensamentos criativos para a elaboração de políticas no futuro. Os três fatores-chave para justificar o interesse do documento em responsabilidade pessoal seriam:

$\triangleright$ A obtenção de resultados de políticas públicas requer maior engajamento e participação dos cidadãos mais do que as tradicionais formas de prover serviços - pois "os governos não podem fazer tudo sozinhos” (Halpern et al., 2004: 27). Um dos exemplos diz respeito ao 'estilo de vida' - os efeitos protetores da dieta e exercícios físicos em termos de saúde.

$\triangleright$ Há fortes argumentos morais e políticos para proteger e aperfeiçoar a responsabilidade pessoal. Dentre eles, o valor dado à capacidade das pessoas e comunidades de assumir controle e agir em função de seus melhores interesses como bens em si mesmos. Neste sentido, a capacidade de agência (agency) pessoal parece ser uma necessidade humana fundamental. E, também, o argumento que o exercício da responsabilidade fortalece o caráter individual e a capacidade moral.

$\triangleright$ Intervenções comportamentais podem ser significantemente mais efetivas em relação aos custos que a provisão tradicional de serviços. Outra vez, dieta adequada para prevenir colapsos cardíacos é uma estratégia mais barata que lidar com as conseqüências de má dieta e cirurgia cardíaca. 
A segunda parte do texto resenha sumariamente 'teorias' e 'modelos' de mudança comportamental, baseados em observações empíricas. Consistem em vários modelos individuais (condicionamento clássico e instrumental, consistência e dissonância cognitiva, heurística e o modelo de processamento de informações do consumidor, modelo dos estágios de mudança e teoria do comportamento programado); interpessoais (teoria cognitiva social, redes de suporte social, influência social e comunicação interpessoal, teorias de atribuição e equilíbrio); e comunitárias (teoria do capital social, difusão de inovações) e condicionalidade (um novo enfoque comportamental baseado em incentivos e desincentivos). Há aqui uma abordagem crítica baseada em evidências empíricas ao modelo comportamental alicerçado no agente racional que procura maximizar suas ações em termos de custo-benefício, pois os pressupostos de tal abordagem raramente são satisfeitos.

A terceira parte traz propostas de aplicação no âmbito de emprego, saúde, criminalidade e educação a partir dos conceitos provenientes de todos estes modelos para abordar os efeitos do estilo de vida/comportamento na saúde - dieta, tabagismo, uso de álcool, inatividade física, falhas no processo de imunização, condução arriscada de veículos, hipertensão nãotratada, não utilização de cintos de segurança, uso de armas de fogo. O lema apresentado é ajudar as pessoas a se ajudarem.

Por fim, são considerados os desafios ao enfoque proposto: aceitação pública, limites da dimensão punitiva da proposta de condicionalidade, preferências individuais e necessidade de personalização e sensibilidade cultural, eficácia das intervenções, riscos de intervenções mal concebidas aumentarem a inequidade e a relação com a responsabilidade coletiva.

Antes de discutirmos o documento, importa delinear a noção de responsabilidade. Sabemos que tal tema permite complexas abordagens ético-filosóficas, jurídico-legais que decerto não cabem aqui. Por enquanto, basta considerarmos que a idéia de responsabilidade, em termos gerais, envolve primordialmente a noção de 'dever' ou 'obrigação' de indivíduos/instituições prestarem contas a instâncias de regulação - concretas ou simbólicas -, por determinadas ações, sejam próprias, sejam de outrem ou relativas a objetos que, através de algum compromisso, lhes foram confiados. Cabe destacar que se está, nestas circunstâncias, sujeito a dimensões da lei, dos usos e costumes e/ou da consciência.

Responsabilidade consiste em uma idéia normativa que enseja e sustenta ordenações essenciais à organização dos coletivos humanos. É conhecida e inevitável a associação de 'risco', 'responsabilidade' e 'culpa' (Douglas, 1992), especialmente no que se refere ao descumprimento das obrigações (esta tematização será desenvolvida mais adiante). 
A retórica da responsabilidade pessoal ${ }^{6}$ e da mudança de comportamento vigente ocorre simultaneamente sob a ambiência do individualismo e da moralidade das sociedades modernas e das crises fiscais e econômicas dos sistemas de bem-estar social de muitas nações. Estes elementos constam do documento. Assim, temos respectivamente a justificativa de que "o exercício da responsabilidade fortalece o caráter individual e a capacidade moral” (p. 7), e a assunção de que "intervenções comportamentais podem ser significantemente mais efetivas em relação aos custos que a provisão tradicional de serviços” (p. 3).

Além disto, convive-se com a idéia de que a 'verdade' só pode ser obtida mediante buscas quase paroxísticas pelo que se convencionou chamar de 'evidências' - emblemas deste discurso de verdade empiricamente correto (ou seja, do que é tangível, pois o que não é retido pelo filtro gerador de evidências, ou tem importância secundária, ou, pior ainda, não existe). Estas irão servir de matéria-prima para a constituição do que estamos chamando 'informes majoritários' - como o documento inglês acerca da responsabilidade pessoal em questão. Ou seja, a dimensão profética que era obtida de modo premonitório pela 'expertise' dos mutantes transgênicos de Dick (ainda que sujeita a falhas) tenta ser alcançada através de resultados, ainda sem garantias satisfatórias de conclusividade, obtidos em estudos empíricos quantitativos. Isto é perceptível na reunião arbitrária de conceitos provenientes dos muitos modelos de mudança comportamental empregados para explicar e justificar modos governamentais de gerir a saúde nos dias de hoje. Utiliza-se freqüentemente a expressão 'evidências empíricas' ou equivalentes como elementos legitimadores para intervenções comportamentais de indivíduos e coletivos humanos. Este fato não é à-toa. Há que se levar em conta que as

\footnotetext{
${ }^{6}$ Discutiremos aqui a 'responsabilidade pessoal', mas é importante considerar que a noção de responsabilidade afeta a qualquer pessoa ou grupo que atua para obter um fim e que pode compreender as conseqüências de seus atos. Responsabilidade está ancorada na noção ontológica de livre arbítrio (free wilh. Em geral, se aceita que afeta os indivíduos, os grupos, o governo dos estados e as empresas. Como deixou bem claro Hannah Arendt (2003), a capacidade de requerer responsabilidade está, inequivocamente, vinculada à existência, à liberdade e se define mediante conhecimento ex ante. Para que alguém possa ser responsável pelo efeito de suas ações deve conhecer ou prever razoavelmente esse efeito antes de produzir a ação e ter capacidade para escolher entre fazê-la e não fazê-la. Não podemos pedir, às pessoas que fumavam antes de Richard Doll e Richard Peto iniciarem seus clássicos estudos, responsabilidades por seus cânceres de pulmão. Além do mais, como veremos a seguir, a classe social pode constituir-se em um fator limitante quanto à capacidade dos indivíduos para escolher livremente.

0 problema central reside no fato de dispormos de uma grande quantidade de informação sobre as consequênncias das ações dos indivíduos, mas as consequiências das ações dos governos e das empresas permanecem em um estado límbico de invisibilidade para a saúde pública e para a opinião pública. Este estado de nosso conhecimento contrasta com a própria teoria da saúde pública. Pois, ainda que esta aceite a existência de causas biológicas, comportamentais e sociais que podem conduzir tanto a indivíduos doentes como a populações doentes, a aplicação do conhecimento disponivel está direcionada ao biológico e comportamental.
} 
origens da ciência moderna estão vinculadas à revolução puritana do século XVII na Inglaterra e que seus primeiros seguidores eram também protestantes praticantes das crenças calvinistas (Merton, 1938).

Sem desconsiderar ingenuamente as inegáveis vantagens e benefícios da abordagem empírica na construção do conhecimento médico-epidemiológico, importa enfatizar, ainda que brevemente, por um lado, a vigorosa busca por hegemonia desta modalidade de pensamento instrumental e, por outro, suas correspondentes decorrências em termos ideológicos, sociais e políticos.

Uma categorização e análise das críticas ao enfoque das evidências na medicina elaborada por Cohen, Stavri e Hersh (2004) é bastante esclarecedora. Uma das críticas, a que mais nos interessa, assinala que as premissas filosóficas vinculadas ao empiricismo evidenciológico que, em sua forma extrema, situa os resultados de estudos experimentais como primordiais em relação a outras formas de conhecimento, assumem a impossível proposição de que observações possam ser feitas de modo totalmente objetivo, independentemente de teorias e da visão de mundo do observador.

Além disto, a definição de 'evidência', mesmo com níveis de pertinência, tem suas limitações. Aquilo que é considerado evidência é passivel de excluir informações relevantes ao conhecimento e à compreensão da situação de saúde, podendo colaborar com mecanismos culpabilizantes. As abordagens baseadas em evidências costumam hierarquizar os resultados dos estudos de acordo com os métodos de coleta, com prioridade para estudos experimentais aleatorizados e metanálises. E, assim, tendem a considerar de importância secundária as informações de caráter qualitativo, de caráter sociocultural e psicológico (quando não a consideram supérfluas), e aquelas referidas a esferas sociopolíticas, que se mostram menos amigáveis aos dispositivos quantitativos numéricos.

A utilidade de aplicar a Medicina Baseada em Evidências (MBE) em casos individuais é restrita em função das circunstâncias pessoais que fazem com que valores individuais variem idiossincraticamente e, também, pelo fato de haver uma grande possibilidade de ocorrência de manifestações atípicas de doenças. De modo que, para muitos pacientes, podem não existir evidências satisfatórias para sustentar as ações médicas. Curiosamente, a avaliação da própria $\mathrm{MBE}$ padece de um aparente paradoxo. Conforme suas premissas metodológicas, para legitimar determinada ação em saúde, são necessários ensaios clínicos aleatorizados e estudos de metanálise que demonstrem eficácia dos efeitos estudados em relação aos gruposcontrole. Pois não há 'evidências' originárias mediante esta ordem de estudos que assegurem empiricamente a eficácia superior das decisões clínicas provenientes da MBE em comparação à assistência de saúde a pacientes através de outros enfoques clínicos não-evidenciológicos (Cohen et al., 2004).

Ao final desta parte, um comentário sobre o título. Talvez seja o caso de indagar-se se, além de descrever com pertinência o tema do documento, poderíamos nos aventurar a uma interpretação um pouco mais enviesada e, decerto, provocadora. Ou seja, pensar que, em 
função dos sortilégios polissêmicos, a expressão 'estado do conhecimento', além de referir-se ao sentido de situação das coisas que são conhecidas em relação às mudanças que atuam nesta condição, também pode ter uma outra leitura, em que se entenda 'Estado' em sua conotação de 'unidade política'. Então, teríamos o Estado do Conhecimento ${ }^{7}$ como uma entidade política de traços neoplatônicos que se ergue para além dos fragilizados estados nacionais, onde o que se designa como conhecimento que vai reger suas políticas provém de estudos empíricos geradores de discursos de verdade - destituídos de enfoques estruturais teóricos e filosóficos razoavelmente consistentes. Os muitos estudos que geram tais 'evidências', de certa forma, vão servir de base para constituir os informes majoritários como o documento inglês.

É preciso deixar claro que não se pretende adotar aqui uma postura anticientífica, obscurantista ou de menosprezo pelas abordagens empiricistas no terreno da saúde. Sem dúvida, alguns indiscutíveis avanços neste terreno são capazes de proporcionar melhores condições de saúde às pessoas que têm acesso a estas benesses. Mas há certos dilemas, perplexidades e talvez equívocos que poderiam ser mais bem abordados diante da assunção de que talvez estes discursos sanitários sejam compatíveis com o espírito de nossa época. E que até mesmo seriam sintomas destes tempos, mudando, assim, a ênfase hegemônica da discussão em termos tecnicistas para incluir as negligenciadas dimensões filosóficas da produção do conhecimento. Talvez partindo de outro ponto, seja possível refazer os caminhos labirínticos que aparentemente não parecem nos conduzir aos melhores destinos. Giddens (1979) defendia que o estudo da sociologia é a busca por alternativas para o futuro - não somente do que é, mas do que poderia ser. Em termos mais bem-humorados, há uma anedota irlandesa contada por Bauman (2003) ao relatar que, diante da pergunta de um motorista desorientado acerca de como ir a Dublin, um transeunte diz que, se quisesse ir a Dublin, não partiria deste ponto.

\footnotetext{
7 Uma leitura ainda mais radical foi realizada pelo filósofo espanhol Fernando Savater, cunhando a idéia do Estado Clínico. Para ele, a única explicação do enorme esforço financeiro que realizam os governos dos países desenvolvidos em saúde, em termos de aliviar o sofrimento humano, levando em conta ser tão pobre a efetividade da prática médica, é o seu papel inovador no controle social, superior ao do aparato jurídicopolicial ou das igrejas.

A mudança do controle social sobre indivíduos ou grupos para o enfoque comportamental contém um aspecto totalizante e amedrontador: literalmente ninguém está a salvo de que 'sua conduta' não seja associada a uma enfermidade no próximo número do The Lancet. Mas, sobretudo, abriu um dilema de grandes proporções na filosofia do direito, uma vez que se negam as garantias legais básicas. Se a sociedade quer castigar as pessoas por seus estilos de vida, isto deveria ser feito sob regras que não fossem menos estritas que 0 direito penal. Isto é, as leis devem ser estabelecidas de antemão e ser conhecidas por todos, deve haver direito a escutar as partes, e o juiz, o acusador e quem executa a pena não podem ser a mesma pessoa. Tudo isto afeta de modo bastante insatisfatório a atual prática da medicina.
} 
Caso estejamos de acordo em que há motivos para descontentamentos com o atual estado de coisas, e, ademais, concordarmos que há necessidade de buscarmos alternativas, não podemos abrir mão de buscar as melhores interpretações possiveis de nossas hipercomplexas sociedades para poder atuar politicamente.

No campo da saúde, é cada vez mais insana a integração sem críticas de pesquisadores e acadêmicos à 'linha de montagem' na produção compulsiva e irrealista de artigos em revistas científicas $^{8}$ (preferencialmente de alto impacto, mas evitando possíveis traumas nestes intentos) e ao discurso de busca 'exaustiva' por evidências empiricistas.

Mesmo tendo uma definição estabelecida no âmbito bibliométrico, é curioso o emprego do 'exaustivo' nesta última designação. Uma vez que não é possível realizar uma busca 'completa' ou total, ou o mais próximo disto, usa-se um adjetivo para indicar que se fez o máximo possível em termos de procura de qualidade e legitimidade na busca geradora de evidências - a ponto de chegar-se à exaustão...

Além disto, como as supostas evidências vão atuar como representantes da verdade, podemos postular que estas fazem parte, sem entrar nos méritos epistemológicos da proposta de conhecimento evidenciológica, de um sintoma de formação reativa diante de desconcertantes e inquietantes níveis de incerteza da época.

${ }^{8}$ Os dois autores desempenhamos tarefas como editores em revistas científicas, e nos chama a atenção quão pouco se valoriza a imaginação e a introdução de enfoques alternativos no contexto das publicações acadêmicas em saúde. Tanto em espanhol como em português chama a atenção que 0 anglicismo 'medicina baseada em evidências' tenha tido tanto êxito, ao invés de uma tradução mais adequada, como seria 'medicina baseada em provas'. Talvez a resposta esteja localizada, de alguma forma, na falta de imaginação que antes comentávamos, já que tanto em espanhol como em português, o evidente é 0 óbvio. Literalmente, MBE seria a medicina baseada em obviedades. 



\section{(Pré)culpa, Responsabilidade Individual e Regulação Moral}

Um estudo de Dodds publicado na revista Health em 2002 aborda as mensagens de responsabilidade que aparecem na produção de textos informativos da promoção em saúde inglesa acerca de HIV/Aids. A investigação mostra como coexistem tanto enfoques simplistas patologizantes das vítimas (segundo os quais quem é sadio é responsável e quem é irresponsável adoece), como os que enunciam responsabilidades sociais e organizacionais relativas à prevenção da Aids. O autor afirma que mensagens isoladas culpabilizantes não estimulam quem as lê a enfocar a situação mais ampla da epidemia, trazendo sérias implicações para os esforços de prevenção do HIV (Dodds, 2002).

Nosso propósito, agora, é adentrar no movediço campo das definições de culpa. Sabe-se que a idéia de culpa envolve, antes de tudo, um julgamento e a desaprovação de alguém em função de alguma falha, transgressão (como falta, pecado, delito, ofensa etc.) em relação à moral ou às leis vigentes em um determinado contexto. Inevitavelmente, está ligada à noção de responsabilidade, ou seja, a capacidade de responder socialmente pelos próprios atos.

Em termos gerais, a culpabilização é um poderoso fator de ordem social que normatiza e procura viabilizar o convivio humano. A ameaça de culpabilização pode ser constrangedora para a maioria das pessoas, apesar de alguns não se mostrarem afetáveis por esta condição e, por isto, serem encarados como inaptos para a vida em comum. A atribuição de culpa geralmente estigmatiza os indivíduos e embute um juízo social depreciativo ao culpável.

No entanto, em casos extremos de êxito financeiro sem que o indivíduo caia nos dispositivos de controle, é possível que se infiltre uma ponta de admiração pela ousadia transgressiva - como o sentimento que pode ser despertado pelas obras de ficção em que grandes roubos ou falcatruas são bem-sucedidos.

Mas, para aqueles indivíduos tementes aos aparelhos repressivos e suscetíveis a ameaças culpabilizantes, o sentimento de culpa pode ser algo muito desagradável. Afinal, também diz respeito a uma excruciante manifestação emocional, em que o indivíduo se sente desvalido, merecedor de punições. Há uma atmosfera opressiva diante de modos de pensar em que se reitera obsessivamente que se 'deveria ter', 'precisava ter', 'poderia ter' realizado ou não realizado uma enunciação ou ato que estava em nosso universo de possibilidades. Quando 
se percebe que houve falha, há um deslocamento de nossa idéia de competência e, por associação, de valor pessoal, uma discrepância subjetiva em relação a nós mesmos (Soffer, 2005).

No terreno da saúde, a idéia de 'culpabilização da vítima' não é recente. Há um debate nos anos 1977/78 entre Knowles (1977) e Crawford (1977) sobre a responsabilização do indivíduo por seu adoecimento. Originalmente, a culpabilização do doente por sua doença foi desenvolvida por Ryan (1976) em seu livro justamente denominado Blaming the Victim, indicando que se trata de localizar as causas de problemas sociais nos indivíduos que sofrem seus efeitos, ao invés de buscar razões de ordem social. Um exemplo trivial nos inseguros dias de hoje é responsabilizar pessoas que eventualmente sofrem assaltos e agressões físicas pelo fato de elas se permitirem transitar em determinados locais em horas consideradas indevidas. Como se fosse possível determinar ambos com precisão. Ou ao fato de se exporem a estilos de vida não-saudáveis que podem levá-las a correspondentes adoecimentos, supostamente por esta razão.

Talvez se possa afirmar que a atual ênfase dos discursos moralistas em direção à culpa esteja diretamente relacionada ao aparente enfraquecimento ético da idéia de responsabilidade como elemento ordenador das relações entre pessoas. Mas esta interpretação pode ser precipitada. É preciso nos deter um pouco mais na noção de responsabilidade pessoal e de culpa no âmbito da saúde.

Apesar do aparente truísmo, importa indicar que os discursos acerca da responsabilidade pessoal em saúde são situados contextualmente. Ou seja, estão vinculados a determinados contextos sociais e culturais e a seus correspondentes valores e normas. Portanto, o que é considerado 'irresponsabilidade' sempre se relaciona com a definição das obrigações sociais e da regulação dos modos de agir. E também em função das noções de 'risco' postas em operação. Seja no sentido de estratégias de evitação, seja no de formas de exposição (Guttman $\&$ Ressler, 2001).

Uma das possibilidades de aprofundar esta discussão sobre a imputação de culpabilidade foi proposta por Guttman e Ressler (2001), ao descreverem as facetas da responsabilidade pessoal (RP) em campanhas de saúde:

$\triangleright$ Suposições de causação e atribuição de culpa: o chamamento à RP sempre assume nexos causais entre as ações das pessoas e eventos de saúde, mesmo que não haja certeza destas conexões. Como decorrência, fica implícita a culpa no caso de ocorrerem efeitos adversos quando não foram tomadas as medidas de proteção. Neste sentido, a partir dos pressupostos causais, surgem importante aspectos éticos:

Uma pessoa deve ser responsabilizada legalmente por efeitos adversos de ações danosas apenas quando está sob o domínio de sua total volição (entendamos como intencionalidade - algo bastante próximo à idéia jurídica de dolo). Há aqui a dificuldade de se estabelecer o que de fato seria a vontade humana e a respectiva possibilidade de controlá-la. Como saber quão conscientes são as ações supostamente danosas à saúde? 
Além da dimensão volitiva, teria que se definir se é para o próprio prazer pessoal ou para o benefício de outros. Surgem os problemas de estabelecer o que serve ao benefício público, decidir se o prazer pessoal pode ser encarado como um objetivo da sociedade.

Há limitações para demarcar a participação de outros fatores não comportamentais na gênese causal de agravos à saúde. É sumamente discutível assumir as mensurações epidemiológicas agregadas de risco como suficientes para estabelecer a RP nos processos de causação. E, também atribuir o comportamento individual a 'elementos internos' de difícil definição como personalidade, caráter, força de vontade, não levando em conta as determinantes contextuais nas ações das pessoas.

Apelos à RP podem potencializar pessoas a agirem em busca de benefícios à sua saúde, mas também podem propiciar a atribuição de culpa e inevitabilidade aos mais vulneráveis.

Em síntese, todas estas dimensões estão inarredavelmente submetidas a difíceis escolhas conceituais e carreiam ao mesmo tempo sutis e graves implicações jurídicas, morais, políticas e sociais conforme as definições escolhidas.

$\triangleright$ Além disto, a RP em relação à saúde apresenta outra faceta: diz respeito à idéia de 'dever/obrigação'. Estas podem se apresentar em termos de cuidar da sua saúde, por seu próprio bem ou pelo bem de seus entes queridos e pelo bem da sociedade onde se vive.

É inegável qua a idéia de dever/obrigação contém alto teor moral, fortemente reforçado por determinados discursos religiosos quanto à obrigação/dever de agir de modo virtuoso e ajudar aos próximos. Mas se somos chamados a auxiliar desvalidos, ao mesmo tempo podese discutir o quanto somos responsáveis por indivíduos supostamente dotados de volição para fazerem suas escolhas de vida. Este seria um ponto cego nestas formulações. Em termos das relações mais próximas, entre familiares, parece haver, conforme os casos, justificativas suficientes para intervir no sentido de proteger o outro. Mas quando estes outros entes vão se constituindo como estranhos, este sentimento vai se desvanecendo, podendo até mesmo chegar à indiferença. Este último aspecto pode se manifestar em sociedades competitivas nas quais se agudiza o conflito entre o cidadão - que procura se dedicar ao bem comum e o indivíduo - que disputa vantagens com rivais em ambientes competitivos.

$\triangleright$ Ainda, há que se levar em conta o discurso da 'capacidade de agência' nas campanhas de saúde. Este fator trata das condições de consciência e posse dos meios necessários (conhecimento, habilidades, recursos e ambiente favorável) para saber decidir os melhores cursos de ação e ter liberdade para evitar situações ameaçadoras à saúde. A capacidade de agência costuma ser apresentada como um item central em vários discursos de organismos responsáveis pela saúde. Como vimos, aparece tanto 
como uma das habilidades de vida (life skills) da OMS como nos argumentos do documento para discussão do governo inglês para incentivar a responsabilidade pessoal em mudanças de comportamento.

Porém, os elementos que consideram tal capacidade, além de trazerem à tona a delimitação aparentemente contraditória do que seria a autonomia individualista humana, não costumam ser acessíveis a grande parte da população do planeta. Sustentar que o indivíduo é responsável por sua saúde é sumamente discutível no caso de pobreza. Nestas circunstâncias, não colocar os determinantes socioeconômicos culturais e ambientais em perspectiva costuma criar o cenário para a culpabilização das vítimas.

A discussão da responsabilidade não permite adotar uma perspectiva destituída de discordâncias em que os interlocutores cheguem a um consenso sem tensões. Ao contrário, este parece ser um campo controverso (Cruz, 2005). Martin (2001) faz uma provocativa discussão destes temas do ponto de vista ético-filosófico. Considera que as afirmações sobre a responsabilização e a culpabilização de vítimas em um contexto é relevante, mas não define o que é enunciado em outros contextos. Por exemplo: na prevenção de doenças, na atribuição de responsabilidade legal indenizatória por danos (liability) em termos de despesas de saúde, na busca por significado do sofrimento humano, na interação com profissionais de saúde. A responsabilização assumiria especial importância, especialmente se levarmos em conta a elevação dos custos médicos, a redução do financiamento público para atenção à saúde, a ampliação da informação médica e de sua grande disponibilização ao público.

Diante das distintas maneiras de encarar responsabilidade e culpa, é preciso definir com mais cuidado suas respectivas circunstâncias e tipos. Por exemplo, Dworkin (1981) sugere uma discutível tipologia com três tipos de responsabilidade.

$\triangleright$ De papel (role): a atuação em termos biológicos, onde o corpo de cada um pertence a si-próprio - premissa muito afim com afirmações individualistas, e, ao mesmo tempo, limitada, pois muitas sociedades consideram consideram crime a tentativa de suicídio;

$\triangleright$ Causal: as condições de saúde de cada um são, em grande parte, determinadas por escolhas pessoais comportamentais - visão conservadora da pessoa com plenos domínios volitivos em suas eleições e sem considerar as contingências econômicas e socioculturais contextuais que interferem em sua saúde;

$\triangleright$ Indenizatória: relativa a custos e outras conseqüências indesejáveis decorrentes do adoecimento de cada um - ênfase na racionalidade econométrica que se impõe cada vez mais diante do aumento dos custos da atenção à saúde. Não se explicita aqui, a idéia de culpa que subjaz a estes dois últimos tópicos.

Outra abordagem é proposta pelo mesmo Martin (2001), que postula quatro instâncias de culpa (que podem, evidentemente, se misturar): 
$\triangleright$ Por julgamento - atribuição de falha a pessoas moralmente responsáveis;

$\triangleright$ Por obrigação indenizatória - responsabilização por ressarcimentos, custos, punições por conseqüências consideradas danosas;

$\triangleright$ Por censura - expressão pública de repreensão, seja verbal, seja física;

$\triangleright$ Por repercussão subjetiva - sensação de emoções desagradáveis e manifestação de atitudes negativas em relação aos outros (raiva, ódio, ressentimento, mágoa, desprezo) ou a si próprio (vergonha, depressão, remorso).

Ainda que clarificadores para demarcar diferentes instâncias da responsabilidade, estes enfoques ainda demandam maiores desdobramentos. Em uma coletânea de autores de língua hispânica sobre a obra de Bauman, Cristiano (2005) afirma que a sociologia é um campo vinculado com as questões do agir humano e, assim sendo, deve lançar seus instrumentos conceituais para a discussão acerca da 'responsabilidade' e suas vicissitudes. Assim, é preciso compreender que haveria dois planos com racionalidades distintas quando se faz referência a esta questão, seja em termos individuais ou coletivos: o primeiro seria o nível pretérito relativo à obrigação de assumir a vinculação, em termos de haver sido encarregado para isto e pressupor-se uma aceitação, de uma situação que já ocorreu, que demanda algum tipo de correção ou ação indenizatória - terreno da justiça. O segundo, o nível futuro - referente à obrigação de antecipar efeitos de uma cadeia de eventos de modo a evitar acontecimentos indesejáveis - terreno da prevenção.

A partir desta delimitação sucinta, abrem-se três perspectivas de incidência para os discursos e saberes sociológicos:

$\triangleright$ Aspectos sociais da responsabilidade - dimensões institucionais referidas à criação e circulação social de normas e critérios individuais e coletivos para definir a distribuição tanto de obrigações de indenização e compensações como de prevenção de conseqüências;

$\triangleright$ Aspectos relativos à atribuição de responsabilidade - delimitação em termos empíricos da relação entre ações (não obrigatoriamente como causas) e respectivas decorrências;

$\triangleright$ Aspectos relativos à previsão subjetiva - prevenção dos efeitos diretos ou indiretos (intencionais ou não) do ato 'responsável' ou realizado por um agente dotado de responsabilidade (isto é, aquele que assume os efeitos de suas ações, antes de que sejam levadas a cabo).

Para Cristiano (2005), os resultados das elaborações e produções sociológicas nestes âmbitos são precários. De qualquer forma, há estudiosos sobre o tema provenientes da própria medicina, da psicanálise e das disciplinas sócio-antropológicas que adotam uma postura altamente crítica diante das inclinações moralistas dos enfoques correntes acerca de responsabilidade individual. E também de suas propostas de controle social das nossas existências, legitimadas cientificamente pelas disciplinas biomédicas e epidemiológicas para, a partir da perspectiva da 
'saúde totalitária', vigiar e julgar tiranicamente os comportamentos humanos e seus efeitos de normalização sobre a saúde (Fitzpatrick, 2001; Gori \& del Volgo, 2005).

Há estudos de antropologia da saúde que mostram como, ao veicular juízos morais, podem-se gerar danos emocionais a pacientes. Há situações de comunicação a pacientes masculinos suecos quanto a seus níveis elevados de colesterol sangüíneo que trazem mensagens morais implícitas sobre relações sociais, conflitos e modos de lidar com o estresse na vida cotidiana (Sachs, 1996).

Vários aspectos se apresentam como especialmente complexos para permitir a procedência dos julgamentos referentes ao estilo de vida por parte dos médicos e de outros profissionais da saúde. Há que se considerar os problemas para se estabelecer com nitidez os nexos causais entre ações das pessoas e os adoecimentos, em meio a determinações também intrincadas de caráter genético e ambiental ${ }^{9}$ (Van de Vathorst \& Alvarez-Dardet, 2000). Mas, sobretudo, é preciso assumir as mencionadas dificuldades de entender o que move o que se convencionou chamar 'vontade humana'.

Para Cruz (2005), a idéia de responsabilidade individual está sendo bastante explorada pelo atual neoconservadorismo, que mal disfarça seus intuitos de desmobilizar e esvaziar a noção de responsabilidade coletiva. Afinal, esta implicaria comprometimentos solidários com grupos sociais excluídos, com seus respectivos e indesejáveis custos.

No entanto, o filósofo espanhol considera indevida a aproximação que se faz entre responsabilidade e culpa. Para ele, a primeira se localiza em uma dimensão intersubjetiva, dialógica, enquanto a segunda, marcada por suas origens judaico-cristãs, se caracteriza pela intra-subjetividade.

Em certo nível, Cruz tem razão, mas parece não se deter nas distinções entre sentimento de culpa e outra instâncias de culpabilização instituídas de modo 'extraintersubjetivo' (voltaremos a este tópico adiante). Por outro lado, é importante a reelaboração que faz das perguntas essenciais na discussão de responsabilidade - além de 'quem' é responsável e de 'quê' somos responsáveis, é preciso ter claro 'ante quem'. No caso da responsabilização pessoal na saúde, o 'ante quem' se dirige para em vetor culpabilizante reforçar instâncias intrasubjetivas e se diluem os aspectos ideológicos extrasubjetivos conservadores instituintes desta ênfase.

${ }^{9} \mathrm{~A}$ existência de um suficiente nivel de conhecimento para estabelecer relações de causa-efeito seria também um pré-requisito para a responsabilidade. Não obstante, apesar da publicidade ideologizada sobre os 'avanços médicos', o prognóstico na atualidade da maioria das causas de morte que nos afligem, como as enfermidades cardíacas ou o câncer, ou das que causam maior quantidade de sofrimento humano, como as enfermidades reumáticas ou mentais, melhoraram somente marginalmente nos últimos 50 anos. Além disto, a mais comum das doenças, o resfriado, continua apresentando a mesma incidência, história natural e prognóstico há 100 anos, e faz 80, com pequenas variações, o mesmo tratamento básico: 0 ácido acetilsalicílico. Não esqueçamos que 0 jargão médico é 0 único que tem até três termos para disfarçar 0 desconhecimento: criptogenético, idiopático e essencial. 
Apesar de bem desenvolvida na literatura de promoção da saúde, a discussão acerca da responsabilidade individual neste âmbito recebeu uma importante elaboração de Ivan Illich (1990). Sem dúvida, o tom é contundente, como as produções deste autor, conhecido sobretudo pela crítica seminal nos anos 70 aos sistemas de saúde ${ }^{10}$ (Illich, 1975). Em um texto baseado em uma palestra dada em Hannover, na Alemanha, Illich é enfático ao declarar, já no título: "Saúde como responsabilidade de cada um - não, obrigado!". Explicita que o 'não' se deve a cinco razões: por desacreditar em uma propalada incapacidade das pessoas leigas em tomarem decisões sobre sua própria saúde - paternalismo profissional; por não considerar que exista uma suposta escassez de recursos para a cura, mas por entender que muitos indivíduos hoje morrem, sobretudo, de fome - ideologia da escassez; por assumir que não haja controles satisfatórios sobre poluentes ou outros agentes e objetos nocivos à saúde de humanos e animais - pensamento sistêmico; por criticar a ética da responsabilidade pela saúde porque tanto a doença como a presença da morte podem ensejar formas de autoconhecimento e, também, porque encara como falta de respeito a aceitação das inevitáveis epidemias da era pós-industrial como um modo superior de saúde - psicologia liberadora; por terem sido destruídos os espaços culturais, técnicos e arquiteturais de muitas populações que, deste modo, se extraviaram de suas herdadas artes relativas ao sofrer e ao morrer o clichê de não haver esperança de reversão para as conseqüências dos mecanismos modernos de desenvolvimento. ${ }^{11}$

Além disto, para Illich, o conceito de saúde na modernidade européia representou uma quebra com a tradição galênica, na qual a saúde consistia em uma fusão harmônica, ordem

${ }^{10}$ Seu artigo seminal "Nemesis médica" foi reimpresso em 2003 pelo Journal of Epidemiology and Community Health (lllich, 2003).

${ }^{11}$ Esta destruição dos recursos e ativos sociais para a saúde é o que llich considerava como iatrogenia social. Uma das consequêencias da medicalização dos futuros que estamos vivendo é a aparição de novas formas de iatrogenia e 0 surgimento de iatrogenias virtuais. Os médicos já não diagnosticam e tratam somente doenças, mas diagnosticam e tratam também riscos. Uma vez que os riscos nem sempre ocorrem, nos encontramos com uma nova situação, inédita na prática médica, em que há efeitos secundários adversos do diagnóstico e do tratamento preventivo de doenças que nunca ocorreriam.

0 contrato implíito da relação médico-paciente se estabelecia na petição de ajuda demandada explicitamente por parte do paciente (autonomia) sob o primado dos princípios da beneficência e da não-maleficência. Uma grande parte da demanda sanitária é, na atualidade, induzida pela medicalização dos futuros circunstância que afeta a autonomia. No que os médicos diagnosticam e tratam riscos, virtualiza-se a noção de beneficência. Se alguém, depois de ter sido tratado para redução de níveis de colesterol sangüineo e hipertensão, não desenvolve infarto, pode-se atribuir este fato, com certeza, à ação médica neste caso concreto? Os médicos na atualidade obtêm créditos para prevenir doenças que não ocorreriam. 0 mesmo sucede com os limites do princípio de não-maleficência, são admissiveis efeitos secundários no diagnóstico e tratamento de enfermidades que não ocorrerão? 0 nivel de dano físico, mental ou econômico deve ser 0 mesmo para diagnosticar e tratar riscos que para diagnosticar e tratar enfermidades? 
estável e interação equilibrada dos elementos básicos. A partir do século XVII, as tentativas de controlar a natureza deslocaram o ideal de saúde como busca de harmonia com o cosmos para a progressiva aparência de algo passível de manipulação. Sob esta premissa, a saúde como 'algo que se possuía' adquiriu aceitação desde o último quarto do século XVIII. No século XIX e no início do século passado, tornou-se natural designar o corpo e a saúde como propriedades do indivíduo, utilizando, para isto, pronomes possessivos - como 'meu' corpo, 'tua' saúde.

Se, naquela época, havia sentido falar de saúde e responsabilidade como ideais dignos de crédito, agora estas noções normativas parecem defasadas e atuam bem mais como elementos desorientadores ou, tão-somente, como argumentos moralmente coercitivos. Seguindo Illich em sua proposta de 'ascese epistemológica', é preciso trilhar outros caminhos para renunciar às certezas indiscutiveis e indiscutidas nas quais se assentam aspectos equivocados da visão de mundo presente. Sobretudo, discursos que, no limite, estabelecem implicitamente a morte como uma adversária. E, sob esta perspectiva, não há vitória possível - quando muito, há a ilusão de que alguns teriam algum controle em termos da maior procrastinação possivel diante do encontro fatídico.

Apesar do característico conteúdo provocador e categórico do discurso illichiano, é importante ter acesso a um pensador que procure desestabilizar conceitos consagrados. Isto serve para a busca da melhor compreensão possível das complexas configurações, pressupostos e insuficiências dos muitos modelos e teorias do mundo ocidental que prevalecem no campo sanitário. 


\section{'Errar é Humano, mas Lançar a Culpa nos Outros É Mais Humano Ainda'}

É preciso abordar uma distinção crucial para nossa discussão: ser culpado e sentir-se culpado têm significados diferentes. Como dizem os perspicazes comentaristas sociais que constituem o grupo humorístico argentino Les Luthiers, "errar é humano, mas lançar a culpa nos outros é mais humano ainda”.

Talvez a importância desta ordem de afetos possa ser aquilatada pela quantidade de substantivos correlatos disponíveis na linguagem - remorso, arrependimento, contrição, penitência, vergonha, vituperação, pecado, consciência. Cabe notar que esta ordem de emoções possui um denominador comum - o fato de se vincularem a relações humanas em contextos de convivio social e também se relacionarem com uma importante noção - a de honra.

Não cabe, por certo, adentrarmos nesta seara. Destacamos, em termos breves, que esta noção se aproxima muito à noção de responsabilidade e à de virtude. Virtude - por um lado, é um sentimento que se institui diante dos olhos julgadores dos outros - como consideração pública pelo mérito diante das boas qualidades humanas. Por outro, consiste no reconhecimento público e nas homenagens por tais predicados.

No entanto, estas idéias podem exalar um certo odor passadista. Nos tempos atuais, teria havido uma certa desregulamentação na ação das forças virtuosas - um possível pleonasmo, pois a raiz etimológica de virtude se refere à 'força eficaz', algo que seria 'próprio' dos homens - daí, 'viril' (<www.etymonline.com/index.php?search=virtue\&searchmode =none $>$. Acesso em: 13 fev. 2005) para, entre outras coisas, permitir o hedonismo sem culpas do consumo viabilizado pelos mercados. Podemos adotar a ótica utilizada por Bauman (2003) quando comenta o enfraquecimento dos sistemas de contenção da energia sexual diante da desregulamentação do processo sublimatório civilizante - onde costumavam residir as dimensões da virtude.

Desde as aceleradas mudanças culturais das últimas décadas do século passado, há pouco lugar, pouco tempo, poucas razões que justifiquem muita procrastinação à realização de desejos cuja satisfação é garantida, apesar de efêmera, pois há mais coisas para serem fruídas. Estamos no primado da oferta enfileirada e atordoante de objetos que devem ser obtidos rapidamente antes de partirmos para o seguinte. Para isto, não há razão para culparmo-nos, pelo menos do modo aparentemente mais denso como faziam os indivíduos do século XX. 
Se essa proposição se sustenta, se flexibilizariam as idéias originárias referentes ao empenho pessoal em termos de virtude, honradez, responsabilidade. Da mesma forma, seus pares antinômicos - sentimento de culpa e irresponsabilidade - se tornam mais maleáveis. Passam a ser aplicáveis em situações em que as faltas se referem a questões mais tópicas pertencentes à esfera da gestão pessoal, como hábitos alimentares, tabagismo, exercícios físicos.

Neste contexto, a manifestação de culpa pode não se dar tanto diante dos outros, como no sentimento de culpa vinculado a faltas sociais graves, mas na relação cotidiana consigo próprio, como no caso de muitos relatos de mulheres que se livram de sentimentos de culpa após livrarem-se de alguns quilogramas.

Mas, este enfoque culpocêntrico pode ter vieses culturais. Como enfatizam Héller \& Féher (1995), a política de (promoção da) saúde busca ser bem-sucedida apelando ao sentimento de culpa massivo, em uma via de 'disciplina e punição', porém, estes rituais angustiantes parecem estar mais enraizados em países de tradição puritana e em sua esfera de influência.

Tal política de saúde segue os cânones do racionalismo vigente, sobretudo em termos de seus princípios norteadores 'universais' que determinam como deveria comportar-se os corpos humanos. Se estes se insubordinarem, serão considerados desviantes, anormais e, portanto, castigáveis. No entanto, o castigo não pode ser improcedente, porque a civilização racionalista é 'equânime'. Deste modo, criam-se instâncias e regras que ordenam, dosam e administram culpas e castigos. ${ }^{12}$

Outra hipótese complementar, a partir de enfoques psicanalíticos, seria considerarmos a ocorrência concomitante de mecanismos denegatórios do sentimento de culpa voltados para fora. Através de ideações paranóides, a ameaça proviria dos outros. Voltaremos a este tema mais adiante.

Há dúvidas quanto aos efeitos de encaminhamentos baseados em responsabilidade pessoal para mudanças de comportamento não serem tão efetivos em termos da prevalência de doenças coronarianas, câncer de pulmão e doenças cérebro-vasculares. Há estudos em que se menciona a dificuldade de realização de mudanças comportamentais ao longo do tempo (Minkler, 1999). Em tempos em que signos, objetos e discursos são evanescentes e episódicos, o que nos leva a esperar que preceitos que apelam à responsabilidade e culpa em promoção em saúde devam ser mais sólidos e de maior aceitação e assimilação?

De qualquer forma, há que se considerar a ênfase de um novo caráter moralista nas complexas sociedades modernas e sua correspondente preocupação com responsabilidade e culpabilização (Innerarity, 2004). Qualquer visão que se ancore a partir de uma perspectiva da moralidade, a partir de raciocínios que visam a estabelecer causas bem definidas, busca localizar e punir responsáveis/culpados por correspondentes faltas. Não é comum, nestas circunstâncias, existir muita disponibilidade para benefícios da dúvida em relação à indefinição das causas efetivas ou da culpabilidade dos réus. Sabidamente, a perspectiva moralista, além de inclinar-se para o maniqueísmo, não costuma reconhecer-se como tal.

${ }^{12}$ Mas, como antes advertíamos, com garantias legais muito limitadas. 
Há, no entanto, engenhosas adaptações proporcionadas pela produção e disponibilização de 'produtos domesticados' no âmbito do consumo. Estes teriam a função de contornar riscos sem grandes privações, através de manipulação tecnológica que 'purificaria' de modo paradoxal os aspectos considerados nocivos pelo conhecimento em saúde vigente. Por exemplo, a existência de produtos 'sem' ou 'des' ou 'com baixos teores' (seja light ou diet) é impressionante: café descafeinado, leite desnatado, cerveja sem álcool, adoçantes sem açúcar. Na indústria alimentícia, é evidente uma busca desenfreada por engodos perceptivos que estimulem as papilas gustativas de modo equivalente aos alimentos deliciosamente arriscados, mediante simulacros o mais inócuos possível. Desde que o acesso ao consumo esteja garantido - visa-se ao máximo possível de prazer. Mas levando em conta o comedimento, pois não se deve descurar das precauções.

O princípio de prevenção/precaução vem se tornando cada vez mais dominante em tempos no quais a consideração de cenários futuros se torna uma constante nas propostas de gestão de vários aspectos da vida. A prevenção de riscos tem suas ambivalências, segundo juízos eventualmente imponderáveis - podem envolver medidas procrastinatórias ou intervenções urgentes (Innerarity, 2004).

Neste caso, o princípio da prevenção ou precaução pode ser usado de acordo com as circunstâncias e, também, com os interesses envolvidos. O exemplo da justificativa da guerra preventiva ao Iraque por parte do Estados Unidos é um triste emblema da política a partir desta racionalidade. Mas, nesta trágica contingência, a constatação da insuficiência das evidências só se confirma depois que o futuro se torna presente.

No caso da prevenção dos riscos em saúde, diante de tantas imponderabilidades que envolvem a determinação e a presentificação de agravos à saúde, mesmo adotando as medidas preventivas, não temos certeza de que os resultados de proteção serão efetivos. ${ }^{13}$

${ }^{13} 0$ castigo ao pré-delito em direito penal aparece nos anos $70 \mathrm{com}$ a punição a indivíduos alcoolizados dirigindo veículos motorizados. Sua introdução nos Estados Unidos, primeiro país não apenas fazer guerras preventivas, mas também castigar pré-delitos, esteve acompanhada de uma interessante discussão sobre se um estado democrático e de direito podia castigar alguém por algo que não havia sucedido. Tal debate estava ancorado no movimento de direitos civis. 0 argumento para perseguir motoristas bêbados se justificaria pelo fato de estes indivíduos apresentarem maior risco potencial à integridade física de terceiros ou aos bens dos demais indivíduos. Foi a primeira conduta categorizada de punição com base na noção de risco.

Até então, essa consideração não se havia aplicado legalmente a condutas, apenas a grupos populacionais minoritários por razões de discriminação étnica ou religiosa, como os judeus, os ciganos e os negros. É interessante notar que é precisamente durante os anos 70 do século passado - quando a maioria dos países desenvolvidos começa a abolir seus aparatos de discriminação social e religiosa - que se inicia a discriminação aos comportamentos. Desaparece o pré-delinqüente e aparece algo mais perigoso e difuso: 0 pré-delito. 
Em suma, retornando à analogia com "The minority report". Os dispositivos de investigação empiricista em saúde sob o enfoque evidenciológico irão municiar os informes majoritários que julgam os estados de risco dos indivíduos. Isso faz com que as pessoas possam ser taxadas como indivíduos passíveis de serem objetos de discursos moralistas de promoção de saúde e passiveis de serem objetos de intervenção das ações de promoção e prevenção de saúde.

Agora, o fato de cada um expor-se, inapelavelmente, a determinados riscos (especialmente aqueles relacionados a aspectos comportamentais) permite que se cogite que o conhecido jargão estatístico 'estimação de riscos' poderia albergar também o sentido de que cada um de nós tem nossos 'riscos de estimação', que assumem dimensões importantes na constituição de nossas identidades. Por isto devemos aprender a conviver com a exposição aos riscos e a administrá-la com especial cuidado, dedicação e, de preferência, com carinho. Sem movimentos bruscos no sentido de eliminação sumária da exposição, pois as conseqüências podem não ser somente benéficas. Em geral, pouco se comenta acerca dos preços a pagar pela supressão de fontes importantes de prazer. Veja-se, por exemplo, a dificuldade de abrir mão de hábitos adquiridos.

O processo conhecido como 'culpar a vítima' assumiria atualmente dois outros desdobramentos no âmbito da promoção em saúde: 'aterrorizar o apreensivo' ou 'constranger aos embaraçáveis' - aqueles que tentam seguir criteriosamente preceitos da promoção em saúde e adotar estratégias de evitação à exposição aos riscos, tanto quanto isto seja possível, no dia a dia; 'responsabilizar o negligente' - aqueles que se expõem a propalados riscos de saúde de modo incauto, sem adotar comportamentos considerados saudáveis. ${ }^{14}$ Ou seja, na vigência dos preceitos da promoção em saúde e do estatuto dos 'indivíduos sob risco' (Kenen, 1996), o fato de estas pessoas se exporem aos chamados riscos comportamentais já as coloca candidatas à pecha de 'irresponsáveis' - passíveis de receberem manifestações de crítica em termos morais por sua falta de autocuidado. Isto ocorreria antes mesmo de se constituírem em possíveis vítimas de suas próprias atitudes, eventualmente consideradas negligentes em termos de saúde.

Através de uma fusão de palavras (de gosto duvidoso, admitamos), a 'higienética' é um modo de nos referirmos a dimensões do controle moral relativas a noções de autocuidado ensejada pela promoção da saúde individualista - a ética da nova higiene. A promoção da

\footnotetext{
${ }^{14}$ A culpabilização das vítimas supõe também um problema a partir do princípio ético de autonomia. 0 problema das vítimas culpabilizadas é que elas nunca solicitaram explicitamente que se julgassem suas condutas. 0 problema da falta de demanda explícita para a saúde pública nos leva a outra questão mais séria. De onde provém a legitimidade da saúde pública para atuar? Poucos autores tentaram responder a esta pergunta crucial para o desenvolvimento profissional e científico da saúde pública. A resposta está em uma vaga apelação ao Estado e aos governos que nos brindam sua legitimidade oblíqua. Nesta transação, sem dúvida, as autoridades sanitárias utilizam uma legitimidade indireta a partir de uma legitimidade alegadamente científica obtida da saúde pública para intervir.
} 
saúde individualista reflete uma nova moralidade vigente no campo dos discursos da saúde: a respectiva busca por causas evidentes para regular condutas em direção a novas idéias de higiene comportamental em época de altos custos para ações de saúde.

Porém, como assinalam Héller \& Féher (1995) a partir da obra de Elias sobre o processo civilizador, as origens desta tendência de higiene comportamental não são recentes. Esta se caracteriza pela forte inclinação, própria da modernidade, a esconder os vestígios da existência do corpo e de suas manifestações. Nas vivendas, são perceptíveis as formas quase secretas, fora do alcance da visão pública, como certas funções da fisiologia humana devem ser exercidas. Há duas razões, a princípio separadas, para o processo civilizador se ancorar nestes propósitos. A primeira seria a higiênica, o modo como a ciência moderna lida com os desafios destes tempos, diante das condições de superpopulação das cidades e das correspondentes formas de contágio epidêmico. A segunda maneira seria a ética, a primazia do racional, como instância 'espiritual', que procura se impor aos imperativos inconvenientes dos corpos. No entanto, a 'nova' higiene postula outros aspectos de nossos corpos como passíveis fontes de constrangimento, embaraço, vergonha - como a presença de gordura localizada, odores corporais, marcas dermatológicas, halitose e, por que não, sinais visíveis de envelhecimento (seja na pele, seja nos fâneros) (Hughes, 2005).

Por outro lado, quando empregamos o termo 'ridículo' para designar alguém ou alguma situação, em geral não parece estar tão evidente que sua raiz etimológica é a de algo que provoca risos, e, sim, diz respeito ao fato de ocorrer uma manifestação de assimetria imaginária de posição social nas relações pessoais. Isto se dá quando alguém enuncia algo que não é considerado como digno de seriedade e/ou protagoniza uma situação em que é responsável por produzir uma ação que resulta em erro ou equívoco. Gera-se um clima de inadequação e, portanto, passível de provocar sentimentos de vergonha no causador. O senso de ridículo pode funcionar como um elemento inibidor de atitudes ou de enunciados que não sigam certas expectativas de responsabilidade ou padrões civilizatórios.

O medo ao ridículo pode participar do exercício de controle social informal em tempos de tentativas de produção de uma nova moralidade. Este tipo de moralidade se dá como efeito aparentemente paradoxal em um contexto ambivalente - ao mesmo tempo em que se estimula a fruição dos múltiplos objetos geradores de prazeres oferecidos pelo mercado com graus variados de exposição ao risco, tenta-se, quando não a evitação, pelo menos o comedimento e a temperança para modular-se o desfrute.

Convive-se, então, com uma dimensão idiossincrática de cada pessoa que parece exercitar 'cálculos' das relações de contabilidade imaginária das relações de 'custo-sacrifício' ao exercer o jogo infindável de administração cotidiana da exposição aos riscos em termos abertura/fechamento com os desdobramentos em termos de pecado/contrição, ou crime/ castigo. Por vezes, o estado de prelibação anterior a uma sujeição a riscos pode até se dar por uma purgação preventiva. 
Há uma nova moralidade de mercado - ou seja, uma forma de regulação que impele indivíduos a afastarem-se dos princípios morais, como a virtude, o bem, a honestidade etc., socialmente vigentes em períodos pré-globalização e a seguirem padrões e formas de sentir, pensar e atuar sob a égide de alta competitividade que marca o âmbito laboral e de busca individualista por satisfação.

No campo das condutas saudáveis em saúde, há situações em que os fatores regulatórios não demandam o emprego de mecanismos como os que envolvem os potencialmente dolorosos sentimentos de culpa. De certa forma, é possível apelar-se para um eventual componente da culpa, menos intenso e mais transitório que costuma acompanhar o senso de ridículo - o sentimento de vergonha. A obesidade e as muitas chacotas que, em geral, ridicularizam os que a sofrem, serve de exemplo a esta tese. Obesos podem, conforme as contingências, sentir as pressões e constrangimentos que sua aparência pode provocar.

Há também transtornos referidos à imagem corporal, no qual o sentimento de vergonha é predominante. Ou seja, aqui não se trata tanto do mecanismo de 'culpar a vítima', mas, como nos referimos anteriormente, ao de 'constranger aos envergonháveis'. Apesar das indiscutíveis razões de prevenção a enfermidades decorrentes do tabagismo, em alguns contextos, a inibição ao tabagismo parece envolver a geração deste tipo de sentimento.

No entanto, atualmente, tem-se a impressão que a sensação de ridículo parece haver se ampliado na cultura de massas. As pessoas parecem sentir mais medo do ridículo do que nunca. Para evitar esta sensação, seguem regras, padrões, modismos para evitar a possibilidade de serem vistas pelo olhar dos outros como ridículas - ou, no limite, como pertencentes a um escalão social inferior. Como se a lógica do espetáculo e da busca de atenção que predomina nos meios de comunicação se difundisse no dia-a-dia das pessoas. 


\section{5}

\section{Crentes, Descrentes, Famintos e a Promoção de Saúde Alimentar}

O campo da alimentação é um bom exemplo de um terreno superpovoado por uma pletora de signos, símbolos e discursos vinculados a hábitos e à cultura dos povos. Muitas vezes, as culturas locais ou tradicionais entram em conflito com enunciados nutricionais provenientes das biociências, em geral, e da epidemiologia, em particular. Os resultados e correspondentes interpretações provenientes de muitas investigações nestes âmbitos acadêmicos sustentam recomendações reguladoras da promoção em saúde.

Neste caso, os indivíduos são convocados a fazer escolhas racionais sobre seus hábitos alimentares, depois de expostos às 'evidências científicas' sobre alimentação e saúde. As campanhas nutricionais parecem incidir na mesma ênfase na assunção de hábitos alimentares sadios por parte de pessoas que entendem seus problemas e escolhem as melhores soluções possíveis para eles (Coveney, 1998).

Mas isto não resolve satisfatoriamente os desdobramentos sociopolíticos da questão. A consagração biocientífica da patologização da obesidade como fator de risco para várias afecções graves ilustra bem este ponto. Se não parece haver mais dúvidas quanto a isto no âmbito acadêmico-científico, é importante ter em conta que, na arena pública, enfatiza-se a questão de 'quem' ou 'o quê' é o responsável por causar e curar tal 'epidemia', de modo a orientar as medidas de enfrentamento do problema. Segundo Lawrence (2004), há duas maneiras de interpretar o 'quem' é responsável pela epidemia ou por seu fim: a individualizante e a sistêmica.

A primeira via restringe as supostas causas da situação a indivíduos particulares, em geral aqueles afetados pelo problema. $\mathrm{O}$ enquadramento sistêmico amplia o foco, atribuindo responsabilidade a governos, mercados e forças sociais. Claro que estes modelos não costumam se apresentar puros na realidade. Talvez seja mais útil encará-los como pólos de um continuum discursivo. Quanto mais o padrão geral do discurso se dirige ao pólo sistêmico, mais as políticas públicas devem ser dirigidas ao âmbito institucional como a arena responsável para lidar com os problemas que envolvem grupos e interesses poderosos. Definir o problema em termos individualizantes reduz a responsabilidade governamental e amplifica a responsabilidade pessoal para enfrentar o problema.

Uma investigação realizada por Nathanson nos Estados Unidos (1999) identificou três aspectos-chave relativos a como os riscos à saúde eram enquadrados de modo a influenciar 
respostas sob a forma de políticas públicas: se o risco é considerado como sendo adquirido deliberadamente ou involuntariamente - e a vítima era vista respectivamente como culpada ou inocente; se o risco é encarado como universal - todos estamos sob este risco -, ou como particular - somente alguns estão sob este risco; se o risco provém do ambiente ou de uma pessoa. Uma quarta dimensão pode ser acrescentada: uma vez que o risco é aceito como 'real', se o perigo foi criado por outrem, intencionalmente, com conhecimento de causa, então isto é essencial para atribuir culpa. Quanto mais uma questão é enquadrada em termos de risco voluntário, particular, genético e produzido voluntariamente, é mais provável que os caminhos para solucionar tais problemas inclinem-se para a alçada da responsabilização pessoal.

A saúde pública se caracterizou, por muito tempo, como um terreno onde se devia privilegiar a abordagem populacional ou pública dos problemas de saúde. Mas, desde o surgimento do movimento da 'promoção de saúde' nos anos 1980, a ênfase coletiva se dirigiu progressivamente para o âmbito individualístico do comportamento ou do 'estilo de vida'.

Surge outra fonte curiosa de patologização dos hábitos alimentares - a ortorexia - uma suposta condição (suposta porque ainda não validada pelas taxonomias acadêmicas) na qual existiria um transtorno alimentar com muita afinidade com um quadro obsessivo-compulsivo em que haveria uma constante preocupação das pessoas com a alimentação saudável. A origem da condição merece atenção para ilustrar a gênese contemporânea de uma potencial 'patologia'.

Steven Bratman, antes de se tornar um praticante da medicina alternativa, era um cultivador de alimentos orgânicos e trabalhava como cozinheiro em uma grande comunidade ao norte de Nova York. Ele valorizava muito as práticas alimentares como elementos importantes no tratamento de muitas doenças crônicas e na manutenção da boa saúde. 'Valorizava', porque suas crenças no poder curativo da dieta se reduziram consideravelmente. Se antes era um militante mais radical do poder da alimentação em termos de saúde, agora, ele as considera como um tratamento aos moldes de qualquer intervenção farmacológica, inclusive com efeitos adversos. Alega que seu entusiasmo diminuiu muito porque perdeu a esperança de que algum dia se vai chegar a uma teoria dietética universal que permita determinar a dieta ideal para cada pessoa. E também porque concluiu não ser possivel tratar os pacientes de forma integral e uniforme com terapias alimentares.

O desencanto começou nos seus dias comunais, quando tinha de preparar comidas para atender insistentes pedidos de refeições separadas com pratos específicos dos aficionados em nutrição saudável que constituíam os integrantes da comuna. Cada um tinha suas teorias nutricionais particulares. Por exemplo, havia os que só aceitavam comida vegetariana e entravam em conflito com aqueles que demandavam carne - e por isto, ela deveria ser cozida em uma cozinha à parte e em recipientes distintos para que as 'vibrações carnais' não contaminassem as panelas. Havia também conflitos entre adeptos de alimentos crus e macrobióticos, bem como disputas quanto à procedência dos ingredientes em termos de 
suas condições de pureza e não contaminação. Por sua vez, os consumidores da comida indiana queriam evitar a cebola, por seus efeitos afrodisíacos.

Este relato - que transita pela caricatura - pode ser encontrada no site de Bratman (www.orthorexia.com), mais especificamente no link referente ao artigo proveniente do Yoga Journal em 1997, onde publicou o texto original em que cunhou o nome e a entidade 'ortorexia nervosa'. Neste texto, Bratman também descreve os sentimentos pseudoespirituais que cercam os adeptos destas práticas.

A ingestão ritual de comidas encaradas como 'puras' cumpre uma função de transcendência purificante - uma prática de bioascese. Os adeptos buscam o aperfeiçoamento moral também por intermédio da comida. Mas, diante de muitas tentações, eventualmente ocorrem quedas que podem envolver refeições com guloseimas 'impuras' - incluindo, chocolates, sorvetes, pizzas. Nestas circunstâncias, para retornar ao 'estado de graça', são necessárias dietas mais estritas que atuam como condenação e assumem o papel de atos de penitência para superar os sentimentos de culpa. A vida destas pessoas passa a girar em termos de regimes alimentares.

Bratman oferece em seu portal um autoteste para diagnosticar a doença com base em uma escala que inclui os seguintes itens: passar mais de três horas ao dia pensando sobre comida saudável; planejar no dia anterior o menu do dia seguinte; sentir-se virtuoso em relação ao que come, mesmo não desfrutando-o em termos de prazer; restringir continuamente a quantidade de comidas ingeridas; experimentar redução na qualidade de vida ou isolamento social (por imperativos dietéticos); sentir-se crítico em relação ao que outros comem ao comparar com seus próprios hábitos alimentares; rejeitar comidas que já foram de agrado para comer os alimentos 'certos'; sentir-se culpado ou se auto-recriminando quando sai da sua dieta; sentir-se em total controle quando come a comida correta.

A ortorexia nervosa ainda não é classificada como doença pelas taxonomias médicas, mas já há investigações que podem levar a isto, legitimando sua existência, como o estudo de prevalência feito por Donini et al. (2004) do Istituto di Scienza dell'Alimentazione, Università degli Studi di Roma La Sapienza, Itália.

O estudo propõe um procedimento diagnóstico e tenta verificar a prevalência da ortorexia nervosa. $\mathrm{O}$ diagnóstico se baseava tanto na presença de um transtorno com traços de personalidade obsessivo-compulsiva como com um padrão exagerado de conduta relativa à alimentação saudável. De 404 indivíduos examinados, 28 (quase 7\%) sofreriam de ortorexia nervosa, com maior prevalência em homens e em níveis educacionais mais baixos.

Sob uma perspectiva histórico-epistemológica, é fascinante acompanhar movimentos originários de geração de uma entidade nosológica. Não importa, no caso, se o desfecho resultará na legitimação do estatuto de existência da 'ortorexia nervosa' pelos compêndios taxonômicos ou não. Até porque há evidentes aproximações deste transtorno com estados definidos como transtornos obsessivo-compulsivos ou condições ligadas a estados psicóticos de caráter paranóide. 
De qualquer forma, os 'dispositivos de inscrição' da ortorexia nervosa já foram postos em ação, como podemos perceber no estudo de diagnóstico e prevalência - a escala mencionada anteriormente teria permitido produzir e, decerto, poderá replicar o 'fenômeno' 'ortorexia' em outras investigações. Os dados de prevalência obtidos corroborariam a validade do dispositivo ao desvelar o fenômeno e mensurá-lo.

Sob o ponto de vista sociológico, a ortorexia nervosa - legitimada como existente ou não - pode ser encarada como um sintoma disfuncional e excessivo nos modos como a preocupação com a autopromoção da saúde se manifesta em seus extremos. Pode assumir dimensões dramáticas, em seus formatos obsessivo-compulsivos - que se manifestam principalmente pelos aspectos ritualísticos incontrolavelmente repetitivos, tanto em termos de pensamento como de ação -, mas também paranóides - pelas facetas eventualmente delirantes de 'ascese espiritual' no ato de ingesta purificada e purificante de alimentos.

Mas, de alguma forma, não parece absurdo pensar que determinados discursos de promoção de saúde apelam para a gestão racional da saúde por parte das pessoas que devem domesticar seus impulsos hedonistas através de esforços de autocontrole para evitar o contato com fontes de prazer - no caso em foco, de caráter gustativo. E isto tem efeitos adversos tanto no que se refere à exacerbação da presente atmosfera de moralidade como à correspondente tentativa de ampliação da magnitude culpabilizante. Esta condição pode refletir estados paroxísticos a que podem chegar as práticas bioascéticas, em que o indivíduo constrói sua bioidentidade somática (Ortega, 2003).

Uma outra hipótese explicativa da incidência de estados adictivos e obsessivo-compulsivos de nossos tempos é indicada por Giddens (2002) para pensar certos traços geradores de compulsões vinculadas ao estilo de vida próprio das sociedades capitalistas avançadas (tais como transtornos alimentares, uso excessivo de Internet, falta de limites na aquisição de bens de consumo). O sociólogo inglês analisa o papel repetitivo dos costumes, rituais e cerimoniais - em geral, de cunho religioso - nas sociedades ditas tradicionais ou fundamentalistas para a constituição de identidades culturais estáveis dos seus integrantes. Tais tradições heterônomas devem prosseguir na medida em que continuarem sendo sustentadas e legitimadas em sua capacidade de produção de subjetividades em modalidades de laços sociais e de modos de ordenação social.

Nas sociedades cosmopolitas ocidentais, há um significativo recuo no papel das tradições - e enfraquecimento de rituais coletivos. Predominam formas consideradas mais autônomas, dinâmicas e individualistas de construir identidades plásticas e, portanto, cambiáveis ao longo das trajetórias em aberto da vida. Ora, para este modelo instável de construção de identidade, a idéia de 'escolher' estilos de vida dentro do 'menu' sociocultural dominante é um convite irrecusável. Atua como eixo na constante busca de auto-ordenação disponibilizada pelos ambientes vigentes, onde há proliferação de bens e mercadorias no âmbito da produção, alta circulação no setor de distribuição e frenesis no pólo do consumo. 
O efeito adverso desta configuração localiza-se no que Giddens (2000) chama "autonomia congelada”: geração de múltiplos e incessantes rituais individuais que podem se manifestar como dependências. Há uma epidemia de excessos: estados obsessivo-compulsivos, variados tipos de dependência e de adicções, dificuldades em estabelecer limites e aderir a regras. Se nas sociedades heterônomas, tradicionais, o passado estrutura o presente através de crenças e rituais compartilhados; nas sociedades autônomas, diferentemente do que sugere Giddens (2002), o dependente não estaria escravizado ao passado por não conseguir fugir do que uma vez foram hábitos de estilo de vida livremente escolhidos. Mas, sim, está prisioneiro de um presente que não cessa de se reconfigurar em looping, onde prevalece a obrigação de usufruir a liberdade de escolher frágeis vetores produtores de identidade. No caso em foco, um vetor precário constituído pelos estilos de vida tomando, na medida do possivel, muitos cuidados para não optar por escolhas insalubres.

Infelizmente, a saúde promocional, em suas formulações científicas hegemônicas, não costuma dedicar a necessária atenção em relação a dimensões socioculturais cruciais e a questões relativas a seus fundamentos filosóficos. Como conseqüência, sofre de graves tensões teóricas que as fragilizam grandemente. Seus conteúdos acabam afetados por afirmações cujo significado ou é ilimitado, ou é destituído de sentido, ou, quando há algum sentido, este é bastante restrito (Seedhouse, 1997). ${ }^{15}$

Sob o prisma político, a promoção da saúde se tornou um movimento que não lidou satisfatoriamente com os problemas-chave filosóficos no núcleo dos pensamentos políticos de direita e esquerda (consideremos que estas categorias ainda tenham uma sensibilidade epistemológica satisfatória): explicar a relação do livre-arbítrio com o determinismo, nem a concepção de 'boa sociedade', nem do que possa ser a condição humana - quanto se é livre (autônomo) ou se é socialmente determinado? E o que é ser livre?

Aqui, mais uma vez, se manifestam os problemas de inteligibilidade das categorias disponíveis. O próprio entendimento do que é ser livre pode ser ambíguo nos tempos atuais: livre para se competir e consumir no livre mercado? Livre das injunções econômicas para recusar,

15 Um dos problemas que esta situação produziu na promoção da saúde é seu ancoramento no paradigma médico e a ausência de um corpo teórico próprio. Esse campo, sob uma retórica de apelos a uma saúde positiva, na realidade, põe em prática uma promoção da não-doença. Somente um teórico da promoção da saúde, Aaron Antonovsky (1923-1994), tentou articular uma verdadeira teoria da geração da saúde, conhecida com o nome de salutogênese. Para ele, era muito mais interessante estudar as origens da saúde que as causas da doença e entendia como sendo mais humano incentivar aquelas coisas que favoreciam a saúde que evitar as que produziam a doença. Antonovsky chegou a operacionalizar em um questionário suas proposições de 'sentido de coerência' ou a capacidade dos indivíduos de entender e abordar seu entorno usando adequadamente os recursos que este lhe oferece. Uma recente revisão sistemática de 458 trabaIhos cientificos que usaram o questionário de Antonovsky conclui que seu instrumento é capaz de predizer realmente a saúde, inclusive no longo prazo (Eriksson \& Lindström, 2005). 
sem prejuízos, encaminhamentos em relação a necessidades sociais e poder escolher trajetórias alternativas?

Mais tragicamente sintomático é o uso de eufemismos que retiram o teor crucial das contingências ensejadas pela configuração geopolítica e econômica dos nossos tempos para indicar algo para além de determinados hábitos alimentares ou estratégias dúbias de promoção à saúde. Vale trazer ao nosso foco a indigna presença da fome em grandes contingentes populacionais em muitas partes do planeta.

A saúde pública tende a padecer de uma tensão primordial nas relações entre o nível de organização pertinente ao indivíduo e aquele relativo ao coletivo. Tal característica pode se manifestar de diferentes formas e demandar distintos tratamentos. Como se sabe, isto pode incidir, por exemplo, no risco de falácias (agregativa/ecológica) ao tentar estudar aspectos pertencentes aos indivíduos ou às sociedades ao transitar entre tais níveis de organização. Afinal, a terrível experiência individual da fome na atualidade se atenua demasiadamente e se 'transforma' em termos coletivos em algo relativamente anódino denominado 'insegurança alimentar'.

Aqui, vale a pena um exercício argumentativo que beira o absurdo para deixar clara nossa posição, mesmo incorrendo na possibilidade de cairmos em uma retórica sofística Façamos uma analogia com a dor. A partir de Michel Serres (2001), um dos grandes acontecimentos do século passado foi a possibilidade de maior controle sobre a dor somática, através do desenvolvimento de potentes analgésicos e anestésicos que são largamente utilizados na medicina moderna. Agora, como pensar em termos coletivos a dimensão da dor individual, experiência humana intransferivel?

Decerto a expressão 'insegurança analgésica' se mostra insatisfatória e absurda para tal finalidade. Nitidamente, a relação que os indivíduos estabelecem com o alimento não se assemelha à desenvolvida com fármacos anestésicos e antiálgicos. A humanidade não sobreviveria sem alimentos e nem temos a necessidade de especialistas para atuar como intermediários, receitando alimentos. Não há 'necessidade', mas sabemos que, atualmente, existem muitos especialistas nutricionais que estabelecem as formas mais sadias de alimentar-se em termos individuais e coletivos, com vistas à promoção da saúde.

Além disso, no interior da expressão 'segurança alimentar' existe, tanto em português como em espanhol, uma imprecisão que não esclarece algo específico aos problemas da fome. Em inglês, temos food security para designar facetas ligadas às precariedades da insuficiência ou escassez de comida, seja na produção, na estabilidade dos fluxos de distribuição e no acesso. E food safety para indicar aspectos relativos às precariedades da suficiência (ou do excesso) de alimento em termos de qualidade e inocuidade (sem contaminação - seja por contaminantes biológicos ou químicos). Ainda assim, há algo de famélico e que provoca malestar pela indignidade que se atenua indevidamente ao tratarmos a fome das pessoas como algo impessoal sob a designação técnica 'insegurança alimentar'. 


\section{6 \\ Vigiar(-se) e Prevenir(-se): a saúde persecutória}

"Para aqueles que não encontram tempo suficiente no seu dia para se preocupar com todos os perigos possíveis da vida, este é um novo livro que vai ajudá-los a priorizar". Assim começa a apresentação da obra de David Ropeik e George Gray (2002) - dois acadêmicos do Harvard Center for Risk Analysis - contida na livraria virtual Amazon. O título Risk: a practical guide for deciding what's really safe and what's really dangerous in the world around you - Risco: um guia prático para a decidir o que é realmente seguro e o que é realmente perigoso no mundo que te cerca (〈www.amazon.com/Risk-Practical-Deciding-Really-Dangerous/dp/0618143726〉. Acesso em: 13 dez. 2005).

O livro é composto por verbetes com elementos indicativos do conhecimento disponivel sobre ameaças potenciais de vários tipos (doenças, acidentes, poluentes ambientais) e fontes (telefones celulares, armas biológicas, pesticidas, contaminação de alimentos, erros médicos) e correspondentes indicações de estratégias de redução do risco. Há até mesmo um 'riscômetro' - tabela em que se verificam a probabilidade de exposição aos riscos e a severidade das respectivas conseqüências desta exposição.

Já na introdução, o tom é ponderado e benevolente ao assinalar que, apesar dos perigos, o mundo estaria mais seguro do que nunca (entenda-se 'mundo das democracias ocidentais avançadas economicamente'). Dados sanitários provariam isto: baixas taxas de mortalidade infantil, alta expectativa de vida, doenças letais erradicadas, avanços em saúde pública, medicina, regulação ambiental, segurança alimentar, proteção ocupacional.

Mas há que se assumir que novos riscos surgiram - e eles citam "resíduos tóxicos, poder nuclear, alimentos geneticamente modificados, doença da vaca louca, redução da camada de ozônio" (Ropeik \& Gray, 2002: 3). Os indiscutíveis avanços tecnológicos que trazem tantos benefícios são infelizmente acompanhados de novos perigos. A maioria de nós sente mais medo e considera que a vida tem muitos perigos, mais do que nunca. Segundo os autores deste livro, tudo isto estaria demonstrado em pesquisas de opinião. 
Nesta breve descrição do livro e do início da introdução da obra, observam-se a sintomática dos tempos atuais e algumas premissas dos discursos hegemônicos da saúde. Destacam-se:

$\triangleright$ A forma de pensar e sentir da maioria das pessoas das sociedades modernas, que consideram que o tempo é insuficiente para as necessidades de gestão cotidiana da grande profusão de elementos e informações aparentemente essenciais à vida de hoje;

$\triangleright$ O constante e incoercível sentimento de insegurança que afeta as populações de muitas partes do mundo (algo que seria aparentemente despropositado diante da comparação com o passado recente);

$\triangleright$ A ênfase ao enfoque racional que seria fundamental para a decisão dos custos e benefícios envolvidos na imprescindível avaliação dos inúmeros riscos de nossos atos e movimentos mais prosaicos (aspecto da governamentalidade neoliberal que se denomina 'prudencialismo');

$\triangleright$ Os dilemas e perplexidades diante da virtualidade e das dificuldades de decifrar a realidade que nos cerca; o poder da ciência em ajudar a sanar problemas gerados por seus produtos tecnológicos.

Em nossa tentativa de estabelecer nexos entre análises sociais e discursos sanitários predominantes, pretendemos agora discutir um ponto delicado em nossa argumentação. Vamos partir de um ponto consensual, ou seja, de que o risco epidemiológico é um dos elementos centrais nas estratégias de promoção da saúde. Em termos gerais e sintéticos, tratase de buscar medidas de prevenção aos múltiplos riscos passíveis de gerar agravos à saúde de todos nós.

Cabe ressaltar que não se trata, aqui, de menosprezar o poder do conhecimento disponível sobre risco, importante nas técnicas e conjuntos de práticas com vistas à prevenção de doenças em nível populacional. Trata-se, sim, tanto de sinalizar sobre possíveis efeitos de exageros em sua utilização, como de ressaltar sua vinculação com aspectos indesejáveis das correntes configurações socioculturais que devem ser aperfeiçoadas. O cálculo do risco tem um papel importante, já que nos permite delinear regularidades e padrões utilizados na prevenção e no controle de situações potencialmente perigosas.

Da mesma forma que Bauman (2005) tece uma crítica ao alcance preditivo da demografia, podemos também fazer a mesma crítica, só que em relação à epidemiologia. As predições epidemiológicas refletem, também, o espírito anímico da época mais do que a capacidade de descrever os desígnios do futuro. Estão bem mais próximas do que gostariam de narrativas proféticas do que de padrões prospectivos que se definem como verazes com o aval da cientificidade.

A epidemiologia é um campo de conhecimentos necessários para o âmbito das análises e intervenções sanitárias. Mas está longe de ser suficiente como, por vezes, aparenta. Como disciplina empiricista, não consegue proporcionar compreensão 
satisfatória (nem assume sua fragilidade neste sentido) diante da complexa dinâmica entre a situação de saúde de pessoas/populações e as aceleradas mudanças socioculturais e subjetivas (que tendem a ser categorizadas de modo demasiadamente simplificador sob a égide das 'variáveis psicossociais'), uma vez que tais variáveis se mostram ainda limitadamente inteligíveis.

Enfim, os discursos sobre o risco indicam a ambivalência da nossa época, que pode se manifestar sob vários formatos e facetas. Uma delas reflete a insegurança emocional tardomoderna, ao mesmo tempo que aponta para o primado (de certa forma, mítico) das certezas veiculadas pelos dispositivos racionais da ciência moderna (Reith, 2004).

Em 2001, Lauritzen e Sachs realizaram, na Suécia, um estudo qualitativo sobre aspectos de risco na comunicação entre pacientes e profissionais da saúde em dois programas de vigilância realizados por enfermeiras especializadas. Os pesquisadores estudaram a apresentação e a introdução de aspectos ameaçadores, por parte das enfermeiras, em um grupo composto por crianças (incluindo a curva de crescimento) e outro de maiores de 40 anos, incluindo determinação de colesterol sangüíneo.

Muitas vezes, os pacientes ou os pais das crianças atendidas não estão interessados nos valores que aparecem nos resultados dos exames, mas, sim, em se os exames são 'normais'. As enfermeiras, por sua vez, não estão seguras em relação aos resultados. Opera-se ambiguamente (mas, a nosso ver, com sabedoria) com duas idéias de normalidade: uma 'instrumental', vinculada aos objetivos e padrões dos programas de vigilância, a partir de estudos epidemiológicos de risco, e outra 'contextual', relativa a contingências situacionais do caso, sendo necessário relativizar o dado populacional para cada indivíduo.

Essa prática de vigilância traz tanto idéias de ameaça como de controle e enfatiza noções de responsabilidade individual com a saúde futura. Além disto, a busca por controle contra os riscos pode aumentar a percepção de ameaças à saúde e a procura por atenção médica, ainda que estas não se justifiquem do ponto de vista clínico. Na medicina vigilante, ${ }^{16} \mathrm{os}$ indivíduos precisam produzir contínuas redescrições subjetivas acerca de seus estatutos como pessoa sadia/normal.

${ }^{16}$ Uma questão preocupante é que, nestes tempos de MBE e de triunfo do ensaio aleatório controlado, ninguém parece preocupar-se com os efeitos adversos e com a eficácia, efetividade e eficiência de submeter as pessoas a processos diagnósticos. Enquanto que nos tratamentos das doenças se exigem níveis de evidência experimental, o diagnóstico continua sendo considerado estruturalmente benéfico, de tal forma que não é necessário aplicar o método experimental. No entanto, partes importantes da iatrogenia de nossas sociedades tecnificadas são as 'doenças diagnostigênicas', ou seja, aquelas situaç̃oes em que os danos são produzidos às pessoas por submetê-las a diagnósticos, especialmente se estes não são requeridos pelo paciente. A razoável proposta de Hipócrates de primum non nocere talvez esteja sendo mais afetada em nossos dias diante da incoercivel necessidade de por etiquetas de doença ou risco em todo 0 mundo. 
Uma abordagem aguda e muito pertinente neste sentido foi desenvolvida por Petr Skrabanek ${ }^{17}$ (1994), em uma obra terminada pouco tempo antes de seu falecimento. O médico tcheco, radicado em Dublin após a Primavera de Praga em 1968, foi um dos membros honorários da Rede Internacional de Céticos ao Colesterol, mencionada no capítulo anterior.

Conhecido por sua verve irônica, ele faz uma magistral crítica às propostas predominantes da ideologia da promoção da saúde individualista a partir do 'sadiismo' (tradução nossa para o português de healthism) - não como necessidade das pessoas, mas como componente de uma doutrina de Estado e do 'estilismo de vida' (lifestylism) - como uma ideologia sustentada pela biomedicina na qual se atribui grande parte da responsabilidade pelo adoecimento a comportamentos não-sadios. $\mathrm{O}$ casamento destas duas perspectivas gera a 'saúde coercitiva', que perverteria os ideais da 'medicina humana' (humane) - que procura diminuir e aliviar o sofrimento das pessoas. Os promotores de saúde atuais seriam os sacerdotes da saúde antecipatória, que apelam para a referência obsessiva aos fatores de risco, constantes esquadrinhamentos e testagens de saúde para detectá-los e prescrições comportamentais para controlá-los (Skrabanek, 1994).

Para a antropóloga Mary Douglas, estudiosa dos aspectos socioculturais do risco (1992), tal noção se presta com muita propriedade à nossa época, em sua ênfase em virtualidade, desejo/necessidade de predição e aceleração e com uma forte ligação com a idéia de culpa. Como se a noção de risco tivesse sido feita sob medida, pois consiste em um termo universal, com poder de síntese, dotado ao mesmo tempo de concretude, em termos de cientificismo e afinidade com análises objetivas e com capacidade de permitir abstrações e proliferações imaginárias.

Por outro lado, o pensamento paranóide vem se constituindo como um sinal representativo de nossos tempos (Innerarity, 2004). Por exemplo, a cinematografia atual é pródiga em enredos deste teor, em que há dúvidas constantes entre o que pertence à ordem do fato 'real' ou ao registro virtual ou imaginário. Mais uma vez, vamos recorrer a este expediente ilustrativo por possuir um valor sintomaticamente representativo para descrever o espírito de nossa época.

Há um filme sombrio, tanto em termos de forma como de conteúdo, produzido em 2003, chamado O Operário (The Machinist), que retrata bem a relação da paranóia com o sentimento de culpa. Trevor, personagem principal, é um empregado de uma fábrica. Não

${ }^{17}$ Skrabanek chegou também a ser uma autoridade mundial em uma obra de James Joyce (Finnegans Wake). Algo incrivel para alguém que, na Primavera de Praga, apenas falava inglês. Seu legado intelectual está sendo divulgado e preservado justamente por quem o acolheu em Dublin, James McCormick. A Skrabanek Foundation oferece um prêmio anual ao melhor artigo científico que proporciona educação ao público, tanto na Irlanda como em outros lugares, com base nos méritos relativos ao ceticismo e apreciação crítica nos campos da medicina e da pesquisa, incluindo a disseminação do conhecimento e dos resultados de investigações desenvolvidas para testar práticas, teorias e tratamentos médicos, sejam geralmente aceitos, sejam 'alternativos'. Ambos escreveram um delicioso livro - Fallacies and Follies in Medicine - que deveria ser de leitura obrigatória em todo o mundo antes de permitir-se que alguém iniciasse sua prática médica. 
dorme há cerca de um ano e apresenta uma grande deterioração em suas condições físicas e mentais. Seus colegas de trabalho começam a tomar atitudes reativas em relação a ele, que se agravam depois que um deles perde um braço em um acidente causado por Trevor.

Uma série de situações ameaçadoras em que não é possível distinguir realidade ou imaginação afetam Trevor, que se vê envolto em uma atmosfera conspiratória em relação a seus colegas de trabalho. Então, passa a investigar os inexplicáveis eventos que lhe atormentam. A todo o tempo se coloca a inevitável pergunta - 'o que é real?' No desfecho, Trevor descobre que somente entregando-se à polícia e assumindo a culpa de um acidente automobilistico fatal - que se lhe havia escapado da consciência - poderá voltar a dormir.

Pois bem, como encarar estes aspectos aparentemente díspares em termos de promoção de saúde? Ao operar com a categoria 'risco', obrigatoriamente estamos entrando no espaço probabilistico futurológico, algo que pode se presentificar, conforme a postulação de determinados valores, obtidos mediante cálculos em estudos com técnicas criadas para esta finalidade.

Mas, pelas próprias características virtuais da categoria risco, não temos certeza absoluta de que ele venha se tornar fato. Indivíduos estão sob risco, mesmo que não apresentem sinais evidentes de adoecimento, mas por indícios propiciados pelos muitos dispositivos médicos de prospecção e vigilância disponiveis. As ameaças nos rondam e devemos estar atentos a isto.

Por um lado, temos a proposta objetivante erigida pelos estudos empíricos populacionais cujos resultados geram os niveis de risco conforme as diversas possibilidades de exposição. Por outro, temos o indivíduo que desconhece se sua exposição irá, no futuro, ter um desfecho dicotômico - inoportuno ou não. Entramos, assim, no interior de um domínio imaginário propício a cogitações que (ainda) carecem de fundamento - no sentido de firmeza, pois seu 'fundamento' primordial é quase simultaneamente especulativo e elucubrativo.

Estamos lidando com feixes de dimensões subjetivas construídas a partir de um discurso racional, mas que, por não se caracterizarem pela certeza e consistência, não proporcionam segurança e, muito menos, tranqüilidade. Pelo contrário, somos obrigados a lidar constantemente com uma atmosfera conspiratória, um terreno muito fértil ao desenvolvimento de pensamentos persecutórios, em que a suspeita de ameaças a nós pode se renovar a qualquer momento.

Uma das possíveis explicações para tal estado de coisas seria a dissolução das responsabilidades em função dos efeitos do individualismo e da denominada 'globalização econômica' e de seus processos causais intrincados, cujos signos costumam se apresentar de modo indecifrável, mas podem interferir acentuadamente em nossas vidas. É ilustrativo perceber como os meios de comunicação informam que as bolsas de valores do planeta entram em instabilidade com explicações que parecem ter sido elaboradas artificialmente a posteriori. As instâncias de poder se tornam difusas e, portanto, desnorteadoras. A estabilidade de nossas vidas cotidianas parece estar sendo decidida em lugares inacessiveis, por entidades misteriosas que poderiam maquinar sobre nossos destinos, sem 
qualquer prurido moral e sem conhecimento de nossa existência. Este é um terreno altamente propício para proliferações paranóides.

Ao mesmo tempo, em termos sintéticos, há que se considerar o desancoramento identitário resultante das muitas transformações sociais da subjetividade, originárias dos acelerados processos sociotécnicos e de suas repercussões em contextos individualistas. Quando as matrizes da subjetividade se tornam simultaneamente múltiplas, descontínuas e ligeiras, a noção de pessoalidade se instabiliza e a sensação de segurança ontológica se reduz drasticamente (Giddens, 2000).

Esse é o cenário para a instalação do homo sanitatis auctor, ${ }^{18}$ o ser humano que promove sua saúde - um ser acossado por ameaças virtuais, indefinidas no espaço e imprevisíveis no tempo, e, que deve, portanto, tomar medidas de prevenção. É necessário apegar-se a princípios de proteção aparentemente menos instáveis proporcionados pela chancela das biociências. Tais conjuntos de regras também podem atuar como próteses identitárias, apesar de suas insuficiências e precariedades.

Cabe aqui a pergunta: será que cada vez mais se irá conceber a idéia de saúde a partir da noção de segurança? E que esta será mediada por exercícios de autovigilância? Um dos encaminhamentos analíticos para lidar com esta ordem conceitual é proposto por alguns autores foucaultianos, como Deborah Lupton. Seus pilares centrais residem na metáfora do panóptico de Bentham, incluindo também, como não poderíamos omitir, o Big Brother da ficção orwelliana - há um fascinante trabalho, originário de uma exposição de arte que ocorreu em Karlsruhe, na Alemanha em 2001, que explora o afã paranóico da hipervigilância atual, intitulada, com criatividade CTRL [SPACE] - A retórica da vigilância de Bentham ao Big Brother (Levin, Frohne \& Weibel, 2002).

Para alguns críticos, na atualidade, a idéia do panóptico não é mais suficiente para lidar com os atuais elementos tecnológicos-comunicacionais na produção da subjetividade (Mathiesen apud Bauman, 2003). No caso da autovigilância, são perceptíveis outros sinais que podem ser representados pela noção de sinóptico. Se, no panóptico, muitos eram observados e controlados por poucos através de postos privilegiados de observação supostamente ativa, no sinóptico, muitos observam passivamente a poucos e se autocontrolam por efeito de demonstração e convencimento (algo próximo ao outro Big Brother, o dos 'espetáculos de realidade' televisiva). Ainda que alguns autores (Boyne, 2000) reiterem o vigor do controle panopticista, inegavelmente, a culpabilização se constitui em um poderoso fator persuasivo de regulação sinóptica. Convivemos nos dias de hoje com profusas mesclas sinópticas-panópticas de vigilância.

\footnotetext{
${ }^{18}$ Agradecemos 0 apoio de Josep Bernabeu, mestre, professor do Departamento de História da Ciência, e de Javier Fresnillo Núnez, professor titular de filologia latina da Faculdade de Filosofia e Letras da Universidade de Alicante, para a elaboração correta desta expressão em latim.
} 
Além disto, a idéia foucaultiana de governamentalidade (uma justaposição de governo com mentalidade) é bastante utilizada. Não vamos aqui entrar no detalhamento das origens da noção (para isto, ver Lemke, 2002). Segundo Lemke (2002), o aspecto de governamentalidade que nos interessa é aquele desenvolvido por Foucault para abordar a capacidade do indivíduo autônomo de autoregular-se e como isto se vincula a dimensões políticas e econômicas de exploração. Muitas das críticas à promoção da saúde e ao neoliberalismo (e como estes se relacionam de modo recursivo) se ancoram a este ponto de vista (Bunton, Nettleton \& Burrows, 1995).

A palavra 'governo' hoje tem um sentido político mas, até o século XVIII também apresentava conotações religiosas, filosóficas médicas e pedagógicas (em português, pode-se empregar no sentido coloquial de 'orientação'). Estas últimas diziam respeito a aspectos de autocontrole, orientação para famílias e crianças, administração do lar, condução da alma. Seria algo como um guia para a conduta, desde a autocondução como a condução dos outros (Lemke, 2001).

A governamentalidade diz respeito a formatos de poder que transcendem ao exercício direto de dominação, mediante a produção de subjetividade. Para isto, segue uma racionalidade que define finalidades de ação e modos apropriados de alcançála. As formas de controle via autogoverno são denominadas 'tecnologias de si mesmo'. Em síntese, o autocuidado é uma estratégia de tornar indivíduos pessoalmente responsáveis pela gestão de riscos socialmente gerados. Um traço marcante da racionalidade neoliberal consiste na justaposição do indivíduo moral e responsável ao indivíduo econômico e racional. A noção de livre arbítrio se escora tanto no sentido do direito de decidir como no da liberdade da escolha. Esta é necessária na equação que desemboca na responsabilidade das ações e de suas conseqüências a este indivíduo.

De acordo com Foucault (1984b), cada moralidade compreende dois componentes: códigos de conduta e formas de subjetivação. Caso queiramos pensar as idéias de responsabilidade e culpa na promoção da saúde e em seus respectivos códigos de conduta saudável na atualidade, precisamos seguir esse autor para analisar as formas com que o cristianismo estabeleceu o modo como as pessoas diziam a verdade sobre si mesmas, e, por extensão, quando ocorrem falhas neste processo.

Dizer a verdade significa necessariamente confessar. É na confissão que observamos os primórdios da subjetividade moderna. É preciso que esta seja um exercício constante de verbalização dos pensamentos (Valverde, 2005).

Contudo, o cristianismo dos primeiros séculos tinha formas diferentes para lidar com a verdade sobre si mesmos. Uma das duas formas principais era designada por exomologesis, ou 'reconhecimento de fato'. Ou seja, assumir publicamente a verdade de sua fé cristã. Mas também havia uma dimensão de penitência.

No início do cristianismo, a penitência não era nem um ato, nem um ritual, mas uma condição imposta a alguém que havia cometido um grave pecado. A exomologesis era uma 
forma de alguém se reconhecer como pecador e penitente, mediante autopunição. Tem o papel de ação propiciadora de auto-revelação que deve ser acompanhada por outros que tem a função de legitimar o processo. $\mathrm{O}$ castigo implica provar sua capacidade de martírio e expiação, mostrar vergonha, exibir humildade e modéstia. Este processo durou até o século XVI (Foucault, 1988).

No século IV, surge outro modo de revelação de si mesmo - exagoresis - que se traduzia nos exercícios de verbalização em relação a um mestre e implicava auto-exame dos pensamentos que surgissem na consciência para avaliar a relação entre ato e pensamento, verdade e realidade. O objetivo era averiguar se havia algo imiscuído nos pensamentos que pudesse desviar o espírito da idéia de Deus.

Em suma, no início do cristianismo, há duas formas de auto-revelação, de mostrar a verdade a respeito de si mesmo. Esta auto-revelação é modelada pela renúncia da vontade e de si próprio. Então, duas tecnologias de si mesmo estão associadas: mortificação do corpo e obrigação de enunciar a verdade dos pensamentos a um outro ao qual se está sujeito. A equação pode ser formulada como sendo o sacrifício de si mesmo para que se possa alcançar a respectiva verdade.

E hoje? Apesar da relevância da pergunta, evidentes dificuldades de interpretação desaconselham leituras apressadas e descrições que possam transitar negligentemente por estes movediços domínios. Os signos da subjetividade em nossos tempos se mostram suficientemente enigmáticos para a permitir decifração imediata. No entanto, pode-se especular, (ou elucubrar), seguindo tendências de análises de autores como Bauman e Giddens, que a verdade sobre si mesmo em nossos tempos é plástica e pode se adaptar às contingências de transitoriedade dos tempos atuais. Ou melhor, 'deve' se adaptar, pois, de outra maneira, pode não acompanhar o acelerado fluxo de acontecimentos que marca nossa época.

Talvez não seja absurdo pensar que uma das fontes importantes de mal-estar e possivelmente de algo no registro da culpa (mas em uma apresentação mais volátil) seja justamente a necessidade de renunciar à vontade e às múltiplas possibilidades de fruição e de satisfação imediata expostas de modo despudoradamente saturante a nosso olhar (mas, infelizmente, inalcançável aos bolsos de muitos).

Assim, é necessário um corpo apto, delgado, atraente de vários modos, não só com beleza física, mas também desfilando sinais indicativos da disponibilidade e abertura a experiências (como indicam certas marcas corporais - tatuagens, piercings). Corpos capazes, sobretudo, de dar conta do máximo de opções e possibilidades que se descortinam nos extensos e variados menus de atividades cotidianas, oferecidos para além das alternativas gastronômicas. Para isto, cabe a realização de 'sacrifícios' auto-infligidos.

Além disto, a relação a mestres/confessores se desfaz. Proliferam, pelos meios de comunicação de massa, modelos constituídos por imagens caleidoscópicas e micronarrativas toscas de exemplos de pessoas e suas vicissitudes ao usufruir aparentemente sem culpa dos prazeres do que se convencionou chamar mundo das celebridades. Ou, como já se disse jocosamente, 
pessoas que são conhecidas justamente por serem conhecidas. E que a isso costumam se dedicar com afinco. Algo que, em uma leitura caricatural, subverteria os sentidos da exomologese - demonstrar publicamente sua disposição a não renunciar aos prazeres - e da exagorese - não parar de ouvir os 'fluxos de pensamentos'. Teríamos, sim, imagens, narrativas e fórmulas de sucesso social emitidas pelos mestres modernos que 'confessam' (eventualmente mediante 'espetáculos de sinceridade') conteúdos que irão constituir modelos sinópticos de comportamento para suas multidões de discípulos.

A análise da promoção da saúde a partir de conceitos foucaultianos é vigorosa e, sem dúvida, não pode ser negligenciada ao abordarmos este tema. Há várias obras de autores autodenominados posfoucauldianos de língua inglesa que discutem com pertinência tais questões (Lupton, 1995; Bunton, Nettleton \& Burrows, 1995; Petersen \& Bunton, 1997).

Há desenvolvimentos teóricos recentes, a partir de filósofos sociais como Agamben, Heller, Arendt, entre outros (Ortega, 2004), que são oportunos a nossos propósitos. Ortega (2004), por exemplo, chama a atenção para as práticas biopolíticas de ascese corporal que através de estratégias de controle disciplinar instituem biossubjetividades que conduzem ao submetimento dos indivíduos. Caso seja possível postular deste modo, o controle de nossas existências na atualidade se dá por injunções biopolíticas baseadas em forte conteúdo moral, dentre as quais práticas sanitárias ocupam lugar de destaque - para além dos mecanismos tradicionais de vigilância e regulação por mecanismos jurídicos e policiais.

Os atores do cenário biopolítico se caracterizam por sua postura individualista e desvinculada do universo da política enquanto arena de negociações para a produção da vida coletiva. Neste mundo, se evanescem tanto a solidariedade como as convicções e crenças na possibilidade de mudanças sociais transformadoras e significativas. As pessoas que podem atuar como agentes no mercado têm a liberdade de escolher e o direito de decidir seus destinos aquisitivos quando e onde bem o entendem. As manifestações da sociabilidade, digamos social, tal como era conhecida se esfacelam diante das propostas auto-referentes da biossociabilidade e do afã consumidor. Para Bauman (2003), a solidariedade humana é a primeira baixa da primazia da lógica contábil dos homo oeconomicus e consumens que buscam otimizar racionalmente nos centros econômicos seus ganhos para a acumulação do capital e seus recursos para passeios nos centros comerciais.

Se o poder motriz das concepções utópicas de caráter político se desfaz, se fortalecem perspectivas autocentradas de aperfeiçoamento pessoal, sobretudo em termos de cuidados preventivos, médicos, estéticos, higiênicos dirigidos, sobretudo, ao próprio corpo. Este seria o ancoradouro fundamental das (bio)identidades pessoais contemporâneas. As idéias-força que eram há pouco tempo constituídas pelas 'utopias' político-sociais cedem terreno às autoreferentes e obsedantes práticas somáticas de, com perdão do jogo de palavras, 'autopia' da nossa época.

A idéia de vida nua - no sentido tão-somente de sobrevida, sem qualquer dimensão de capacidade de ação política qualificada é uma das teses mais conhecidas de Agamben (1995) 
e acompanha sua teorização acerca do homo sacer - a impressionante figura do direito romano antigo que assim denominava o indivíduo cuja existência não era digna nem de ser vivida, nem de ser oferecida como sacrifício ritual aos deuses. Esses indivíduos poderiam ser eliminados sem que sua morte fosse considerada delito, já que não têm o direito à vida garantido pela lei. Vale a pena mencionar que a palavra latina 'sacer' é curiosa em sua ambigüidade polissêmica, por poder significar tanto 'sagrado', 'santificado', como 'maldito', 'devotado à destruição', 'horrivel' (<www.ultralingua.net/index.html?action=define\&sub=1\&searchtype= stemmed\& text=sacer\&service=latin2english $\rangle$ ).

Bauman (2005) retoma a noção dos homini sacri de Agamben e enfatiza com absoluta pertinência que os processos de construção da ordem política e econômica atuais geram as 'populações excedentes'. Tais grupos constituir-se-iam em mais uma variedade de lixo humano - pessoas, que apesar de, em muitos casos, permanecerem dentro do primado das leis, seriam 'vítimas colaterais' - um efeito adverso do presente estado de 'progresso econômico'.

Não é possível fazer de conta que estes seres, ainda que muitas vezes vistos como 'supérfluos', não existam ou que sua produção não aumenta. No entanto, os 'tratamentos de resíduos' propostos, em geral, assumem feições tecnicistas, burocráticas, assepticamente distanciadas e, inevitavelmente, insuficientes, diante da desproporcional magnitude dos processos geradores de lixo (Bauman, 2005). Por vezes, é possível notar, como vimos, signos lingüísticos como emblemas da inadequação dos modos de lidar com tal ordem de problemas, como o uso de 'insegurança alimentar' - um impróprio eufemismo para a abordagem dos graves problemas de fome coletiva.

Talvez não seja absurdo indicar que, para aqueles que podem atuar como agentes de consumo, uma das formas de pensar as práticas de saúde que visam à produção do que podemos chamar de 'sobrevida nua' produza o homo longo aeu ${ }^{19}$ - o indivíduo devotado à sua longevidade - figura gerada pela 'nova saúde pública' que enfatiza certas práticas individualistas e apolíticas de promoção sanitária nas quais o bem supremo é o prolongamento da vida em termos estritos de longevidade, de preferência com o máximo de conforto que seja possível conforme as circunstâncias da vida se apresentem. Mas, cabe perguntar: onde teria surgido esta perspectiva?

Antes, porém, de tentar encaminhar esta questão, é importante aqui assinalar que, para entender como o corpo se fez político, é preciso seguir a Foucault (1984a) e perceber que, com o desenvolvimento agrícola e econômico do século XVIII e o aumento da produtividade e dos recursos, houve um certo desafogo em relação a ameaças como a fome e as epidemias. Nestas circunstâncias, os indivíduos ocidentais começaram a se dar conta de outras implicações do fato de se estar vivo no mundo, de se dispor de um corpo, de modos de existir, de

\footnotetext{
${ }^{19}$ Agradecemos 0 apoio de Josep Bernabeu, mestre, professor do Departamento de História da Ciência, e de Javier Fresnillo Núnez, professor titular de filologia latina da Faculdade de Filosofia e Letras da Universidade de Alicante, para a elaboração correta desta expressão em latim.
} 
probabilidades de sobrevida, de usufruir-se de estados de bem-estar. Todos estes aspectos podiam sofrer variações. A existência biológica tinha efeitos na esfera política. A vida passa, assim, aos domínios do conhecimento e do terreno de intervenção reguladora das instâncias do poder. Tais processos de controle - via contabilizações demográficas e epidemiológicas (nascimentos, casos de doenças, mortalidade por várias causas) - se denominariam 'biopolítica das populações'.

Em geral, os dilemas biopolíticos tendem a contrapor opções entre a liberdade (autonomia) versus vida - seja a vida como 'boa-vida', sem restrições aos prazeres arriscados, ou, ao contrário, com a disciplina para evitar as ameaças à vida e prolongar a sobrevivência. Além disto, nossa civilização não parece ser capaz de "harmonizar com coerência absoluta os valores de liberdade e da vida em todas as alternativas possíveis” (Heller \& Fehér, 1995: 26). O doloroso exemplo atual desta afirmação são as injustificadas matanças de populações civis sob a alegação da guerra em defesa da liberdade.

Outra importante contribuição para a nossa discussão foi desenvolvida por Hannah Arendt (2003). A filósofa alemã aborda a questão da responsabilidade coletiva sob o ponto de vista político. Neste momento, é preciso distinguir entre dois estatutos de responsabilidade: jurídico, mais específico, de caráter punitivo/indenizatório, onde há imputação de autoria de alguma falta que demanda compensação; ético, de dimensões mais amplas, referente à obrigação de responder ativamente (uma 'respondência') como agente no mundo em que se vive, para além dos limites da noção de falta e da correspondente responsabilidade compensatória.

Arendt propõe uma base para compreender como a responsabilidade ética deve ser assumida politicamente, pois, para ela, o político é necessariamente ético e se refere à constituição de um sujeito plural para a ação coletiva. A perspectiva arendtiana distingue claramente o registro moral do político. Para a autora, a responsabilidade surge quando há espaço para a política, por meio da ação coletiva, mas no interior de um arcabouço legal. Evidentemente, há uma fragilidade básica nesta configuração, pois os caminhos da política dependem de acertos instáveis e transitórios entre distintos interesses e desejos (Arendt, 1995).

A responsabilidade política é coletiva e se relaciona ao cuidado com o mundo que compartilhamos com os outros, incluindo, especialmente, os mais fracos. Demanda, além da evitação do mal-agir, a assunção de autoria de atos e de suas consequências, intencionais ou não. Mas, vale repetir, é essencial a busca da ação política que não deve se confinar às propostas biopolíticas de primazia individualista da vida como bem máximo, de onde florescem as noções de responsabilidade pessoal em saúde cujo estatuto não é nem político (em termos qualificados), nem ético, mas que se definiria em um possível arranjo híbrido estético-subjetivo movido a sentimentos difusos nos quais podem se mesclar culpa e vergonha.

Ora, a promoção da saúde é um dos enfoques biopolíticos possíveis dentro das múltiplas configurações biopolíticas e seus respectivos discursos (ecologia, minorias sexuais) existentes. Para Heller \& Fehér (1995), o discurso sanitário surgiu como reação radical conserva- 
dora a um movimento, também biopolítico, da 'boa vida' dos anos 60, que se caracterizou pelos apelos à franca manifestação da sexualidade, ao êxtase e ao uso de drogas (é importante relembrar que Philip K. Dick é um representante da estética cultural destes tempos).

Ao encerrar esta parte de nosso desenvolvimento, cabe descrever um curioso exemplo de supostas referências ao espírito desta época que aparece no terreno da publicidade espanhola com uma reação ao vigoroso discurso atual da responsabilidade individual em saúde atual através de uma engenhosa referência a um dos mais conhecidos vilões do estilo de vida nãosadio: os cigarros de tabaco.

A agência publicitária da Nobel, marca espanhola de cigarros, produziu vários cartazes que invariavelmente consistem em imagens de pessoas desenhadas em um estilo que sugere a estética visual dos anos sessenta em tons amarelo, vermelho, preto e branco. Além disto, estas mesmas imagens e textos estão estrategicamente estampadas nos maços com a visível função de atuar como contra-argumento aos contundentes avisos das autoridades sanitárias acerca dos graves riscos do tabagismo. As mensagens, geralmente, são construídas com uma estrutura aparentemente contraditória. Mas constituem-se em bem urdidos oxímoros, jogando com idéias que dão margem a proposições de caráter hedonista, de certa forma, compatíveis com o espírito dos anos 60.

Vejamos alguns dos textos: 'los mejores sueños los tengo despierto'; 'hay segundos que se hacen eternos'; 'a veces lo más pequeño es lo más grande'; 'cuando dejo de buscar, encuentro'; 'a veces para encontrarme tengo que perderme'; 'a veces ser feliz me hace llorar'; el plan es que no hay plan', 'cuanto más lejos estamos, más cerca te tengo'; 'estar serio me hace reir', 'a veces, el más inteligente es hacerse el tonto'. Em todos, a idéia matriz procura liberar tabagistas da obrigação de comportamentos racionais que sustentem posturas de comedimento responsável que levem a interromper o fumo (em uma das metades semânticas da frase), uma vez que isto os afastariam das possibilidades de usufruir de formas e circunstâncias geradoras de significados mais intensos da vida ligados ao prazer de continuar fumando, ainda que arriscadas (a porção restante da frase). O lema da campanha resulta em um golpe de misericórdia na noção (racional) de responsabilidade individual/obrigação: 'disfruta de tus contradicciones' (〈www.evasanagustin.com/addb/2004/nobel2004〉).

Em síntese, a promoção da saúde hegemônica atual pode ser interpretada como uma política de neo-higiene interna, de forte conteúdo moral com vistas à longevidade ou, no limite, como denegação da morte; com a perspectiva de que nos mantenhamos o mais tempo possível sob a égide globalizada do mundo racional da produtividade e da geração de riquezas, e procurando o impossivel equilibrio esquizofrênico entre a busca de satisfação de desejos propiciados pelas múltiplas tentações oferecidas paroxisticamente ao nosso redor e um comedimento responsável para que não nos consumamos neste vórtice. Ao mesmo tempo, em um estado discreto de alerta de forma a prestar alguma atenção para aqueles 'intrusos' que não podem ter acesso aos centros comerciais, mas capazes, de um momento para outro, espreitar com olhos desejosos ou ameaçadores àqueles que, por vezes despudoradamente, desfrutam dos prazeres do consumo. 


\section{Parte II}

\section{Estilo de Vida, Genômica e Responsabilidade Individual em Saúde}





\section{7 \\ Um Exercício de Sensibilidade Epistemológica}

Prosseguindo em nossa discussão, cabe agora enfocar mais especificamente duas categorias de análise, uma conceitual e a outra disciplinar - estilo de vida e genômica - como fontes de atribuição de responsabilidade no âmbito da promoção da saúde. Trata-se de reconhecer e discutir efeitos de ambas ao atuarem como constituintes essenciais nos modelos de entendimento dos processos de saúde/doença/cuidado/prevenção. No interior destas instâncias são feitas atribuições de determinados sentidos e significados que sustentarão descrições, interpretações e explicações do mundo social-histórico e, também, modalidades de intervenção.

O estilo de vida operaria, no limite, com uma idéia de culpabilidade que pode se avizinhar ao dolo, pois os comportamentos lesivos à saúde poderiam ser relacionados à intencionalidade, na medida em que se supõe que estariam sujeitos ao controle da vontade. $\mathrm{Na}$ genômica, ainda que as possibilidades de controle volitivo sejam indiscutivelmente menores, ${ }^{20}$ surgem pressões para estabelecer responsabilidades pelo desconhecimento de configurações genéticas diante da disponibilidade de testagens gênicas disponíveis.

\footnotetext{
${ }^{20}$ Indiscutivelmente, não sabemos o que ocorrerá no futuro, nem como se gestionará, pessoal e publicamente, a informação genética. Dando continuidade ao nosso costume de recomendar filmes neste livro, Gattaca, de Andrew Niccol (1997), apresenta uma paisagem ao mesmo tempo orwelliana e huxleyana dos efeitos potenciais em nível político e pessoal do conhecimento genético. 0 filme representa, talvez, a primeira exploração narrativa acerca dos potenciais efeitos da genômica na construção social de uma eventual higiene interior.
}

Até os nossos dias, a higiene sempre foi externa aos indivíduos. As causas da enfermidade estiveram primeiro no nivel divino. Com Hipócrates, baixaram à terra e se materializaram em construtos científicos e populares situados fora também dos indivíduos, constituindo-se em humores, miasmas ou microorganismos. Como já comentamos, a promoção da saúde aproximou notavelmente a responsabilidade de adoecer aos individuos e seus costumes. Mas, ainda, como era o lema de Arquivo X, série televisiva dos anos 90, "a verdade está lá fora": 0 corpo humano segue considerando-se um ente mirífico com um potencial saudável que pode desenvolver-se. Um eventual triunfo da genômica como paradigma dominante na biomedicina, como a explicação mais prevalente das causas de adoecimento, seria capaz de trazer acoplada a eventual construção de processos higienizantes que afetariam tanto 0 genoma dos indivíduos como os seus ancestrais. 
Empregaremos aqui uma adaptação metafórica de um operador epidemiológico consagrado. Em epidemiologia, para dimensionar a validade de um teste de screening, podem-se utilizar as seguintes medidas: sensibilidade, especificidade e poder preditivo. Neste caso, interessa-nos abordar apenas a sensibilidade: proporção de pessoas verdadeiramente doentes na população estudada, identificadas como doentes pelo teste de screening. A sensibilidade é uma medida da probabilidade de diagnosticar corretamente um caso ou a probabilidade que, dado um determinado caso, este será identificado corretamente pelo teste (Last, 1989 Tabela 1). A partir da idéia de verdade produzida pelo padrão métrico, opera-se, também nos domínios epidemiológicos, com uma imagem metafórica, enfeixada na noção de 'padrãoouro' - que serve para atuar como base de referência dos protocolos de aferição.

Tabela 1 - Validade de um teste em termos de sensibilidade

\begin{tabular}{l|c|c|c}
\hline \multirow{2}{*}{ Resultados do teste } & \multicolumn{2}{|c|}{ Situação real } & \multirow{2}{*}{ Total } \\
\cline { 2 - 3 } & Doentes & Não-doentes & \\
\hline Positivo & A & B & A + B \\
Negativo & C & D & C + D \\
\hline Total & A + C & B + D & A + B + C + D \\
\hline A - positivos verdadeiros & B - falsos positivos \\
C - falsos negativos & D - verdadeiros negativos \\
Sensibilidade - A/A+C & \\
Fonte: Last, 1989.
\end{tabular}

Agora, para considerar a sensibilidade epistemológica, em termos bastante sucintos, temos antes de considerar que as características do mundo podem ser abordadas em termos de: o que é isto? - ontologia; como se toma conhecimento disto? - epistemologia; o que isto causa? - causação (Searle, 1997). A sensibilidade epistemológica diria respeito a 'quanto' um conceito/noção/categoria/disciplina descreve ou explica aquilo que se pretende conhecer.

As causas do adoecimento não estariam mais no ambiente em torno do indivíduo, e, sim, no genoma, que se traduz ao discurso popular com metáforas totalizantes, como o livro da vida ou o manual de instruções de Deus, entre outros. Quais serão, então, dentro de uma higiene interior, os equivalentes da esterilização e da desinfecção?

Inevitavelmente, o fantasma da eugenia volta a aparecer, sobretudo em um mundo em que há locais onde já se está praticando uma seleção massiva por sexo para favorecer ao nascimento de varões. A eugenia permanece conosco. 0 conceito de missing women foi cunhado há anos para denominar as mulheres que não nasceram ou morreram ainda bebês devido ao aborto seletivo por sexo e à falta de cuidados no período neonatal. Isto simplesmente pode ser valorizado vendo a razão de sexos dos nascimentos, que é muito negativa para as meninas em países como China, Índia ou no Norte da África. 0 prêmio Nobel Amartya Sen (2003) calcula em cerca de 100 milhões o número de mulheres que, em todo o mundo, estariam vivas hoje se esta prática eugênica não estivesse tão difundida. 
Ora, esta 'medida' é impossível de se obter, pois, além de esta questão ser despropositada em sua formulação, ao aliar perspectivas não compatíveis de distintos âmbitos de pertinência, apresenta-se dissociada de vínculos teóricos.

Aliás, justamente, essa seria uma das características da pesquisa empiricista típica, a partir de uma incondicional assunção de poder de desvelar a natureza que, por sua vez, teria a propriedade de esconder a verdade sob vários véus. A ciência, então, teria uma faceta, digamos, obscena ao procurar invariavelmente desnudar o que se apresenta escondido sob mantos de aparências. Para cotejar os resultados do empreendimento científico com tal idéia de realidade que se furta a intimidades fáceis, temos o emprego da noção de 'padrão-ouro', de forte conteúdo metafórico, mas sem assumi-lo como tal.

Não cabe pensar que existam, no discurso epistemológico, quaisquer padrões-ouro para atuar como referência métrica e serem comparados em termos de adequação dos conceitos a seus referentes. Este aparente contra-senso tem a função de assinalar que são as palavras (e suas contingências) que irão configurar categorias e teorias para abordar 'objetos sociológicos' atinentes às ciências da saúde - como é o caso de 'estilo de vida'. Neste caso, a sensibilidade epistemológica consiste em mais um modo de revisitar a relação das palavras com as coisas.

Uma aguda observação de Georges Balandier (1999) merece ser mencionada aqui para ilustrar a problemática contemporânea de se estudarem aspectos da vida social que podem dar margem a controvérsias e permitir distintos entendimentos e definições. O etnólogo francês enfatiza a fragilidade das palavras quando se tentam explicar as vicissitudes da época atual. O vocabulário disponível parece apreender apenas algumas partes do que acontece ao nosso redor. De modo difuso, o que se apreende é confundido com o todo, tornando-se referência até ser substituído rapidamente por outro. Essas construções não podem ser consideradas como verdadeiras ou falsas, já que, de alguma forma, refere-se a porções 'reais' do que existe. Mas, ao mesmo tempo, tal recorte é, muitas vezes, tomado não só como representante fidedigno do todo, mas como sendo o próprio 'todo'. Enfim, temos de admitir que operamos cada vez mais com conceitos e idéias sujeitas a imprecisões e polêmicas (às vezes inconclusivas). Ademais, na atualidade, uma só designação pode ter vários significados.

Ora, os conceitos também participam da construção de 'realidades', uma vez que a linguagem erige categorias que passam a descrever e explicar o mundo a partir de determinados prismas. Em especial, trata-se de discutir aqui as questões de pertinência de 'determinadas' noções e conceitos no terreno de 'determinadas' propostas de promoção da saúde e, também, ao mesmo tempo, procurar delinear perspectivas que podem estar atuando como matrizes das correspondentes propostas de conhecimento. Pretendemos, aqui, desenvolver aspectos conceituais relacionados ao emprego da categoria 'estilo de vida', instituinte de modelos, retóricas e ideologias nas práticas de saúde na biomedicina, na saúde pública e, sobretudo, na promoção da saúde. 



\section{A Promoção de Estilos de Vida Saudável}

Para Lupton (1995), o termo 'promoção da saúde' é geralmente usado para descrever atividades específicas dirigidas a metas particulares, com uma forte ênfase na gestão racional da saúde das populações. A maior ênfase da retórica promocional da saúde está em estimular a 'saúde positiva', em prevenir doenças, mais do que em tratá-las, desenvolver indicadores de desempenho com base em objetivos específicos, o uso da mídia para colocar no mercado comportamentos e atitudes (estilos de vida) saudáveis, o foco no trabalho com comunidades para estimular a respectiva participação nas proposições com vistas a desenvolver ambientes saudáveis e também diminuir os crescentes gastos na assistência à saúde.

A epidemiologia costuma apresentar as relações entre os padrões de doença e os correspondentes riscos de adoecimento em termos de atributos, propriedades e características próprias aos agregados de indivíduos, sem incluir as interações recursivas com seus contextos socioculturais (Frohlich, Corin \& Potvin, 2001). O respectivo controle dos riscos relacionados ao estilo de vida tende a seguir a mesma racionalidade, sendo, muitas vezes, apresentado pelos especialistas da promoção da saúde como algo ligado à esfera privada, da responsabilidade dos indivíduos, colocada em termos de escolhas comportamentais. As respectivas propostas educacionais em saúde visam a atingir mudanças nesta dimensão.

Um exemplo dessa descrição é o Sistema de Vigilância do Fator de Risco Comportamental (Behavioral Risk Factor Surveillance System - BRFSS) do Centro Nacional para a Prevenção de Doença Crônica e Promoção de Saúde (National Center for Chronic Disease Prevention and Health Promotion), do reconhecido Center for Disease Control and Prevention (CDC $)^{21}$ em Atlanta, Estados Unidos. Segundo informações contidas na publicação Health Risks in the United States: behavioral risk factor surveillance system 2003, há cerca de 20 anos o CDC faz, por telefone, inquéritos periódicos de prevalência (surveys) em adultos americanos, para colher informação atualizada sobre uma ampla gama de comportamentos que afetam sua saúde (Estados Unidos, CDC, 2005).

${ }^{21}$ É muito revelador que a instituição de saúde pública mais influente do mundo contenha a palavra 'controle' em sua denominação. E, também, que seja uma instituição ainda militarizada. 
O foco primordial destes estudos tem sido os comportamentos associados a doenças crônicas que se constituem nas maiores causas de morte. Estes comportamentos de alto risco incluem:

Fumar e outras formas de uso de tabaco. Comer alimentos gordurosos e com baixos teores de fibras. Não ter atividade física suficiente. Abusar de álcool ou outras drogas. Não se submeter a métodos médicos comprovados para cuidados preventivos e diagnósticos precoces (por exemplo, vacinação contra resfriados, exame de Papanicolaou do colo de útero, mamografia, colonoscopias). Praticar comportamentos violentos ou comportamentos que causem danos não intencionais (dirigir embriagado). (<www.cdc.gov/nccdphp/ bb_brfss_yrbss/index.htm>)

Assim, "armados com dados de inquéritos científicos, o CDC e outros profissionais de saúde elaboram programas para combater os efeitos dos comportamentos de alto risco". Tais programas tem várias funções: "Informar ao público e aos profissionais de saúde sobre os perigos de certos comportamentos. Promover comportamento saudável. Ajudar as pessoas a pararem com seus comportamentos de risco" (<www.cdc.gov/nccdphp/ bb_brfss_yrbss/index.htm>).

Tais dados também servem para "ajudar o CDC e outras organizações de saúde pública a avaliarem programas de saúde pública e assegurarem que estão na trilha certa na direção da alcançar seus objetivos" (〈www.cdc.gov/nccdphp/bb_brfss_yrbss/index.htm〉).

$\mathrm{O}$ argumento econômico é destacado para justificar o programa:

Os custos médicos para doenças crônicas (a maioria causada por comportamentos de alto risco) atingem 60\% do US\$ 1 trilhão de custo em assistência médica. O custo anual com obesidade é US\$100 milhões, com doenças ligadas à inatividade física, US\$ 76 milhões (em 2000), e ao uso de tabaco, US\$ 50 milhões. (〈www.cdc.gov/nccdphp/bb_brfss_yrbss/index.htm〉)

É importante considerar os benefícios destas abordagens. Há, sem dúvida, efeitos positivos na saúde das pessoas que eventualmente conseguem alterar seus padrões de exposição aos riscos através das chamadas mudanças comportamentais. ${ }^{22}$ Mas tais intentos não são tão eficazes na

${ }^{22}$ No entanto, ainda que assumamos os efeitos positivos através da promoção da saúde, poucas vezes se leva em conta 0 efeito iatrogênico que a própria promoção da saúde é capaz de provocar. A medicina e a cirurgia, em sua relação com os pacientes, aprenderam que sua atividade pode gerar danos e que é necessário um balanço judicioso entre o benefício que provavelmente se cause ao paciente e os danos que possam se manifestar no processo. Ainda não existe uma avaliação da iatrogenia que a promoção da saúde está produzindo. Em geral, prevalece a idéia de que dar informação não pode ser nocivo e os profissionais quase não se preocupam com os efeitos colaterais de suas campanhas. No entanto, a questão ética que aí 
medida desejada pelas autoridades sanitárias. Há algo que resiste a corresponder aos objetivos dos programas de monitoramento de fatores de risco comportamental. Como veremos, as concepções de sociedade, de pessoa e de suas inter-relações adotadas predominantemente pelo campo da saúde promocional parece ser insuficiente para alcançar as metas almejadas.

Vale salientar que a promoção da saúde adota estratégias políticas que abrangem desde posturas conservadoras até perspectivas críticas ditas radicais ou libertárias. Sob a ótica mais conservadora, a promoção da saúde seria um meio de direcionar indivíduos a assumirem a responsabilidade por sua saúde e, ao assim fazerem, reduzirem o peso financeiro na assistência de saúde. Noutra via, reformista, a promoção da saúde atuaria como estratégia para criar mudanças na relação entre cidadãos e o Estado, através da ênfase em políticas públicas e ação intersetorial. $\mathrm{Ou}$, ainda, pode constituir-se em uma perspectiva libertária que busca mudanças sociais mais profundas.

Em geral, as discussões conceituais sobre promoção da saúde tendem a ser inconclusivas, pois suas atividades transitam sobre terrenos teóricos de difícil compatibilização: paternalismo versus 'participacionismo'; individual versus coletivo e com os seguintes enfoques ao longo destes dois eixos: conservador (técnicas persuasivas em saúde), reformista (ação legislativa para a saúde), libertária (aconselhamento pessoal para a saúde) e radical pluralista (educação popular em saúde) (Beattie, 1991). Em outras palavras, cada tipo de promoção da saúde está centrado em uma determinada perspectiva acerca do que deve ser uma boa sociedade (Seedhouse, 1997) e do que seria a natureza/condição humana. Ora, 'boa sociedade' pode ser concebida de diferentes formas, conforme distintas vias filosóficas/sociopolíticas. Ser humano, da mesma forma, pode ser definido a partir de variadas óticas/saberes/disciplinas.

Para as propostas mais conservadoras, parece haver uma ambivalência crucial. Uma boa sociedade deveria ser, ao mesmo tempo, produtiva, competitiva e consumidora no mundo das economias globalizadas, com suas inevitáveis tensões e geração de compulsividades sobre a saúde das pessoas e, ao mesmo tempo, ser comedida em seus estilos de vida, procurando buscar suportes sociais para compensar a solidão e a carência do espírito de comunalidade que marcam as relações nas sociedades ocidentais contemporâneas. Além disto, é necessária alguma definição de condição/natureza humana que permita, conforme algumas proposições comportamentais e cognitivistas, alterar condutas (estilos de vida) não-saudáveis.

subjaz é especialmente grave. Enquanto a medicina e a cirurgia estabelecem um contrato implícito com seus usuários, maximizando o bem e minimizando 0 mal baseadas na demanda explícita de assistência, na promoção da saúde, pelo contrário, não existe uma demanda pessoal explícita. A promoção da saúde invade muitos aspectos da vida de muitas pessoas. Alguns deles, especialmente íntimos. A grande cobertura, populacional e cultural, dos programas de promoção da saúde e a ausência de uma demanda explícita deveriam nos conduzir a uma aplicação muito mais estrita dos princípios de beneficência e não-maleficência na promoção da saúde. A ausência de demanda explícita tem uma única solução: mais participação comunitária. 
Para Lupton (1995), na promoção da saúde, mais especificamente na abordagem educacional dos comportamentos em saúde, empregam-se modelos instrumentais, 'operativos' que se tornam prescritivos, com vistas a intervenções. Mas parece haver uma falta de teoria unificada para a promoção da saúde. Tende-se a utilizar teorias para explicar vínculos entre atitudes e comportamentos, adotando um modelo causal mais do que tentando construir uma epistemologia da saúde pública.

Até agora, a construção de modelos parece ser a fonte primordial para um núcleo teórico. O termo 'modelo' costuma se fundir com 'teoria' na literatura da promoção da saúde. Os muitos modelos aparecem em uma profusão de figuras/esquemas com setas apontando para direção das mudanças ou mostrando alças de retroalimentação cibernética, em meio a 'normas', 'fases', 'estágios', 'forças', 'alvos', 'barreiras', 'recursos', 'necessidade de conhecimentos'. Aliás, como meta primordial para a mudança de comportamentos em direção à saúde veiculada pela promoção da saúde é essencial proporcionar 'informações/conhecimentos' (no sentido de 'evidência' científica) pela via da razão como eixo para atingir o desenvolvimento humano, o progresso e a sustentação da ordem social (Lupton, 1995).

Os modelos comportamentais de caráter conservador em que se postula o 'empoderamento psicológico' dos indivíduos (no sentido de capacitação pela exposição a informações de modo a proporcionar sensação de controle das situações) também se baseiam no 'conhecimento' como veículo central para levar os humanos - seres racionais - a fazerem escolhas conscientes. Esta perspectiva iluminista também está presente em modelos oficiais de participação comunitária. 


\section{Breve Incursão ao Estilo de Vida na Internet e na Academia}

Nos dias de hoje, estilo de vida é uma concepção consagrada em vários âmbitos da vida contemporânea. Podem-se perceber referências a essa idéia nos meios de comunicação de massa e na publicidade, elementos centrais da moderna cultura individualista do consumo. Por exemplo, há, no Brasil, uma revista com esse título, publicada pela editora Abril, que sintomaticamente apregoa em seu site: "A revista Estilo de Vida mostra o que as celebridades usam, onde compram e quanto custa. Com Estilo de Vida, você se inspira, faz suas escolhas e valoriza o seu estilo pessoal" (<www.assineabril.com/ index.html?destino=malhoestilo\&origem=sr/estilo $>$ ).

Nos domínios da medicina, da saúde pública e da promoção da saúde, é constante a utilização desta expressão. Nestes campos, estilo de vida se institui como uma macrocategoria central em várias explicações e teorias científico-acadêmicas sobre os processos de adoecimento nas quais uma concepção racional, volitiva e, por vezes, moralista e individualista da conduta humana atuaria de modo crucial como fator de risco epidemiológico.

Se, por exemplo, pesquisamos 'lifestyle epidemiology' (epidemiologia do estilo de vida) no buscador Google na internet, encontramos 512 resultados em 19 de novembro de 2003, e, cerca de um ano e quatro meses depois, aproximadamente três vezes mais, cerca de 1.490 (em 17 de março de 2005). Curiosamente, muitas vezes, junto a tal expressão costumam coexistir outros vocábulos com a aparente função de destacar aspectos específicos do 'macroconceito': como 'atividade física', 'nutricional' e também 'família'.

Por sua vez, 'lifestyle medicine' trazia quatro mil resultados em 17 de março de 2005. Cabe, aqui, assinalar dois elementos que atuam como sintomas do alcance desta perspectiva. Sob tal categoria, localiza-se, nos Estados Unidos, a home page de uma médica que divulga a prática de 'medicina do estilo de vida pelo telefone' (〈www.hometown.aol.com/zbic/life/>).

A profissional, com doutorado em saúde pública, anuncia serviços individualizados de consultas com vistas à prevenção e tratamento de doenças crônicas sem uso de medicamentos, apenas através de mudanças no estilo de vida. Justifica as consultas por telefone em função da conveniência e da privacidade de estar em casa e dos menores custos em relação às realizadas em consultórios (〈hometown.aol.com/zbic/life/〉). De alguma forma, é possível encarar esta atividade como uma telemodalidade de aconselhamento comportamental. 
Outro exemplo mais ambicioso do uso da noção estilo vida saudável na cultura de consumo de saúde e aptidão: a existência, nos Estados Unidos, do Rippe Lifestyle Institute, dirigido pelo cardiologista James M. Rippe, que desenvolve, entre atividades editoriais e de pesquisa, a avaliação de saúde Rippe (Rippe Health Assessment), que consiste em:

avaliação de riscos à saúde, exames de aptidão (fitness) e avaliação de riscos do estilo de vida para homens e mulheres executivos, outros indivíduos de alto desempenho, indivíduos que buscam melhorar sua saúde e bem estar e todos aqueles dispostos ao compromisso de obter mais da vida.

Sua meta é: "ajudar a empoderar pessoas a levar estilos de vida mais saudáveis com paixão, compromisso e desempenho" (helping empower people to lead healthier lifestyles with passion commitment and performance) (<www.rippelifestyle.com/index.shtml〉).

Rippe é, também, organizador de um volumoso compêndio intitulado Lifestyle Medicine (1.392 páginas) com 116 capítulos, divididos em 21 categorias e 148 colaboradores. O manual explicitamente assume a tarefa de enfrentar os desafios do profissional de saúde diante das sólidas e profusas evidências científicas relativas à relação entre medidas positivas de estilo de vida para boa saúde e as dificuldades de atualização e assimilação na prática clínica. (〈www.blackwellpublishing.com/book.asp?ref=086542294X\&site=1〉). Em outras palavras, propõe uma medicina do estilo de vida baseada em evidências.

Além disso, Rippe disponibiliza a "prescrição para saúde das articulações" (the joint health prescription), na qual alia um suplemento de gelatina, vitamina $\mathrm{C}$ e cálcio a atividades como exercícios de força com alongamentos e caminhadas e que mostra uma "acentuada melhora na saúde das juntas através do uso de um suplemento à base de gelatina - um simples pó que pode ser misturado ao suco de laranja da manhã. O estudo clínico foi um ensaio clínico aleatorizado, duplo-cego, controlado com placebo, usando 200 participantes". (<www.rippelifestyle.com/newscontent/newsstory.shtml〉).

Supondo que o estudo tenha sido feito segundo os cânones metodológicos dos ensaios clínicos aleatorizados, é de se perguntar por que não existe, em seus sites, menção a outros estudos, revisões sistemáticas ou metanálises sobre a relação entre articulações saudáveis e compostos de gelatina, vitamina $\mathrm{C}$ e Cálcio.

Mesmo na literatura médico-epidemiológica considerada séria, há uma visivel inclinação a enfocar padrões comportamentais individuais como responsáveis pela saúde. Se retiradas de seus contextos e das relações sociais, estas condutas perdem seu significado. O estilo de vida seria, então, um 'estilo de risco', conceitualizado como uma pré-patologia. São medidos os fatores de risco comportamentais dos indivíduos para servir ao planejamento de ações de saúde pública. Um exemplo seria o Sistema de Vigilância do Fator de Risco Comportamental (Behavioral Risk Factor Surveillance System, BRFSS) do CDC, nos Estados Unidos, que já analisamos aqui. 
Outro exemplo digno de atenção quanto às tendências definitórias hegemônicas no campo da saúde aparece nos trabalhos de investigação de estilos de vida em distúrbios psiquiátricos em jovens adultos saudáveis, idosos e em casos de estados depressivos e distúrbios de ansiedade (Monk et al., 2002). Aí encontramos uma escala que pretende estabelecer a 'regularidade de estilo de vida'. Com esta finalidade, foi elaborada a Social Rhythm Metric (SRM) para medir quanto a vida cotidiana de uma pessoa era irregular/regular (escores de 0 7) em termos de seus horários e da seqüência dos eventos diários. Uma versão ampliada consistia em 17 itens: 1- sair da cama; 2- primeiro contato com outra pessoa; 3-bebida matinal; 4-desjejum; 5- sair; 6-iniciar trabalho, trabalho doméstico ou atividades voluntárias; 7- almoço; 8- sesta à tarde; 9- jantar; 10- exercícios; 11-lanche noturno; 12-assistir a notícias na TV; 13-assistir a outro programa; 14 -atividade idiossincrática A; 15 - atividade idiossincrática B; 16- última hora de volta para casa; 17-ir para cama. Fizeram-se, também, estudos que validaram uma versão simplificada da escala com cinco itens (a versão completa como padrão-ouro) - 1- sair da cama; 2-primeiro contato com outra pessoa; 3 - iniciar trabalho, trabalho doméstico ou atividades voluntárias (fator 'manhã'); 4-jantar; 5-ir para a cama (fator tarde/noite).

Outra linha vigorosa de estudos se vincula à cruzada que setores ligados a determinadas concepções da medicina desportiva e da educação física exercem contra o 'sedentarismo'. Em alguns casos extremos, tal linha funciona como algo que evoca uma familiaridade não claramente explicitada com o combate puritano a um dos sete pecados capitais, encarado como a matriz dos demais pecados... Esta perspectiva está tão presente nos tempos atuais que, por exemplo, para evitar a perda de continuidade ou desistência da adoção de atividades práticas, há pesquisas que postulam o conceito de 'personalidade da aptidão (física)' que pode ser evidenciada instrumentalmente mediante escalas Likert com sete dimensões ou estilos psicossociais (sociabilidade, espontaneidade, automotivação, agressividade, foco mental e a capacidade de correr riscos). Uma avaliação da personalidade da aptidão (física) permitiria escolha mais específica e compatível com atividades físicas e desportivas mais propícias a cada pessoa, de modo a obter mais adesão e menos desistências às prescrições de exercícios físicos regulares (Gavin, 2005).

Aqui, vale a pena referir-se a uma grande pesquisa comparativa que investiga a 'salubridade' (healthfulness) de estilos de vida em dois grandes países: Estados Unidos da América e China (Kim et al., 2004). Segundo o estudo, foram utilizados dados do Inquérito de Saúde e Nutrição da China de 1993 (amostra de 8.352 indivíduos) e do Inquérito Contínuo de Ingesta de Alimentos por Indivíduos dos Estados Unidos de 1994-1996 (amostra probabilística de 9.750 indivíduos) em pessoas de idade mínima de 20 anos - exclusão de mulheres grávidas ou em lactação. Para isto, os autores utilizam uma complexa escala, denominada índice de estilo de vida (IEV), que consiste em uma medida totalizante de EV criada neste estudo para sumarizar a respectiva salubridade total dos EV, incluindo as recomendações 
atuais em relação a doenças crônicas. O IEV integra aspectos relativos a comportamentos ligados à dieta, atividade física, tabagismo e ingestão de álcool.

Para se ter uma idéia da complexidade da escala, vale a pena determo-nos nos detalhes de seus componentes. A medida da qualidade da dieta com vistas a comparações internacionais avalia quatro dimensões: 'variedade', 'adequação', 'moderação', 'balanço geral' - verificada de duas maneiras: variedade geral (consumo diário de, pelo menos, uma porção de cada um dos distintos grupos alimentares: carne vermelha, ave, pescado, ovos; derivados lácteos, leguminosas; grãos; frutas e vegetais e variedade em relação à ingesta protéica (consumo diário de, pelo menos, três diferentes fontes de proteína (carne, ave, pescado, laticínios, leguminosas e ovos); 'adequação' - avalia o consumo de frutas, vegetais, grãos, proteína, ferro, cálcio, vitamina C, e fibras dietéticas em relação percentual a níveis recomendados; 'moderação' - relativo à ingesta de nutrientes que podem contribuir ao desenvolvimento de doenças crônicas e que, portanto, talvez impliquem restrição - percentual de gorduras totais, gorduras saturadas, alimentos com calorias vazias e níveis de colesterol e sódio; 'balanço geral' - em termos de proporcionalidade da composição de fontes energéticas e ácidos graxos.

Já o índice de atividade física categoriza cinco níveis: muito ativo, ativo, moderado, leve e sedentário. Para o tabagismo, as categorias são: não-fumantes, ex-fumantes e fumantes atuais (em quatro grupos conforme a quantidade de cigarros fumados ao dia). O consumo de álcool é mensurado em relação à ingesta do número de 'doses' ou seja, de $13 \mathrm{~g}$ de álcool, que pode ser em termos de ao redor de $340 \mathrm{ml}$ de cerveja, $140 \mathrm{ml}$ de vinho ou $42,5 \mathrm{ml}$ de destilados.

Assim, homens que bebem mais de cinco 'doses' e mulheres que ingerem mais de quatro por ocasião são considerados bebedores pesados. Tanto abstinentes como bebedores moderados são considerados de modo equivalente, com pontuação máxima, pois não foi possivel identificar efeitos benéficos ou deletérios distintos entre estas categorias. Já bebedores mais que moderados recebem pontuação mais baixa.

A ponderação de cada item no índice final segue a literatura que estabelece que a atividade física e o tabagismo contribuem mais com riscos maiores de doenças. Assim, os pesos são: qualidade da dieta - 0,2; atividade física - 0,3; tabagismo - 0,3; ingesta de álcool - 0,2. Pelos resultados, o estudo conclui que a escala reflete a salubridade dos componentes do estilo de vida em ambos países. A média foi ligeiramente maior na China, superior em qualidade da dieta, atividade física e tabagismo, que nos Estados Unidos - superior em ingesta de álcool.

Poderíamos entrar nos méritos técnicos da investigação e discutir a robustez e validade das escalas para medir o que se propõem a mensurar. Mas o problema se estende para além da dimensão metodológica. Em realidade, são os pressupostos teórico-epistemológicos em relação ao entendimento dos aspectos socioculturais que aparecem de maneira demasiadamente débil e tímida, a ponto de gerar entendimentos potencialmente equivocados do que sejam as sociedades humanas. Por exemplo, ao se considerar apenas como fonte de subnotificação o fato de que a maior atividade física por parte dos chineses (relacionada a 
deslocamentos ao trabalho) seja algo que não está encarado como sendo de alto status social, pois os ricos se dedicam a atividades físicas por lazer. Como fazem os norte-americanos em geral, que se dedicam a tais atividades em função de sua maior possibilidade de acesso e consumo de atividades de lazer.

Além disto, poderia haver mais subestimação nos dados das mulheres chinesas quanto à ingesta de álcool e de tabagismo, ao passo que, nos estadunidenses, pode ter havido subnotificação de ingesta de gordura, pois possuem posturas aversivas às gorduras.

Sem dúvida, há pertinência técnica no fato de os autores assinalarem estes aspectos potencialmente enviesantes para que os resultados do estudo sejam alçados à categoria de 'evidência'. O mais grave, porém, é o forte conteúdo descontextualizador diante da infima relevância atribuída a contingências próprias da dinâmica cultural de cada país, pois talvez isto possa instabilizar a pertinência da comparabilidade eminentemente estatística de populações tão díspares como as pertencentes a estas nações tão populosas e com tantas contradições internas, além de situadas em territórios tão vastos.

Ademais, tais países apresentam profundas diferenças contextuais - tanto sociais, como subjetivas, seja em termos de desenvolvimento histórico, de formas de constituição de identidade, de peso de tradições, de encadeamento de configurações simbólico-sociais, de atribuição de significados a hábitos de vida.

Ainda assim, os autores do estudo incidem em clichês sanitários, ao encerrar o artigo enunciando que o uso do IEV traz "melhor entendimento dos comportamentos do estilo de vida de modo a proporcionar orientação para o desenvolvimento e estabelecimento de metas de atividades de promoção de saúde para melhorar a saúde pública global” (Kim et al., 2004: 169). Podemos cogitar que, intencionalmente ou não, este tipo de estudo acaba por colaborar com um projeto de homogeneização exacerbada de distintos grupos humanos, e as proposições explícitas de melhoria da 'saúde pública global' se coadunam em demasia com propostas implíitias de avanço da economia privada globalizadora.

Outra linha de estudos segue uma tendência equivalente em seus pressupostos, ao procurar detectar precocemente desvios do comportamento para aspectos não salutares em um grupo etário reconhecido por seu desejo de experimentação e por afastar-se das normas usuais. Este foi o objetivo de uma pesquisa realizada em Taiwan sobre o 'estilo de vida adolescente'. Chen et al. (2003) pretendiam e avaliar e validar as propriedades psicométricas de um instrumento denominado 'escala de promoção à saúde adolescente'. Tal escala procura detectar estilos de vida não-sadios em adolescentes taiwaneses em termos de suporte social, apreciação da vida, responsabilidade em saúde, comportamentos nutricionais e administração de estresse.

Os pesquisadores concluíram que o instrumento dispõe de boa validade de construto e confiabilidade para taiwaneses e que assim está assegurada a qualidade de seu uso por enfermeiras de saúde escolar para avaliar programas de promoção de saúde adolescente. Eles defendem que as causas de mortalidade em adolescentes se deslocaram de etiologias infecciosas 
para comportamentais e que os correspondentes padrões de conduta, além de mudarem rapidamente, podem incluir maus hábitos alimentares, de sono, inatividade, condutas arriscadas - incluindo uso de álcool, tabaco e drogas ilícitas, atividade sexual, manejo imprudente de veículos automotores, homicídio e outros crimes violentos. Os autores concluem que estes comportamentos colocam os adolescentes em alto risco de desenvolverem doença e patologia social.

Em termos quiçá simplistas, pode-se afirmar que a adolescência é uma etapa da vida humana em que ocorrem muitas mudanças psicológicas e físicas e em que pode prevalecer um movimento de experimentação e de pôr-se à prova. Ao mesmo tempo, existem situações de riscos vinculados a estas circunstâncias. Porém, as premissas do estudo, além de evitarem abordar as complexas causas estruturais de comportamentos maladaptativos nos tempos atuais, tendem a incorrer em uma postura de prevenção científica que sugere o espírito neomoralista e repressor com que foi retratada a delinqüência adolescente no romance de Anthony Burgess, nos anos 70, que se transformou em um filme consagrado - e censurado naqueles tempos dirigido por Stanley Kubrick: A Clockwork Orange (A Laranja Mecânica). 


\section{Estilos de Vida: individual e coletivo}

$\mathrm{Na}$ atualidade, podemos supor a existência de juízos de valor favoráveis às rotinas de vida padronizadas nas atividades cotidianas. Isto produziria a 'regularidade' no estilo de vida no interior das práticas de promoção de saúde. Além disto, mostra-se como o sedentarismo e o estilo de vida irregular (ou vida desregrada) podem ser quantificados e associados a riscos mais elevados de doenças. Aqui, estudos epidemiológicos, ao mesmo tempo que se preocupam em estudar riscos à saúde, tendem a reforçar, como já vimos anteriormente, dois aspectos imbricados. O primeiro seria a moralização dos 'estilos arriscados de vida' que envolvem elevações de risco - correr riscos em função de comportamentos de pessoas e grupos e dos correspondentes estilos de vida desregrados pode veicular conotações ligadas aos terrenos do 'pecado' ou da 'fraqueza de caráter'. O discurso do risco enfatiza a perspectiva racionalizante, como expressão do puritanismo (comedimento, autocontrole, temperança, prudência). O segundo seria a responsabilização individual: o foco voltado para o controle comportamental individual não enfatiza a busca de transformações de aspectos macrossociais que estimulam condutas chamadas de risco.

Importa comentar, ainda que brevemente, as origens da categoria estilo de vida. Está registrada nas teorias sociológicas clássicas como componente da estratificação social ao enfatizar a importância do conceito na evolução e manutenção de status dos grupos (Backett \& Davison, 1995). Destaca-se a visão de Max Weber no livro Economy and Society: an outline of interpretative sociology, de 1922. Para ele, o estilo de vida era mais do que uma função da classe social determinada economicamente. Tratava-se de uma concepção totalizante que incluía renda, ocupação, educação, status. Weber não encarava as vicissitudes na vida como resultantes apenas de acasos, mas em função das oportunidades que o indivíduo tinha a partir de sua situação social. As oportunidades e as escolhas na vida de cada um seriam socialmente determinadas (Cockerham, Rutten \& Abel, 1997).

Recentemente, a noção tem sido debatida e polemizada por vários autores. Giddens (1991), por exemplo, considera-a como um dos aspectos fundamentais da cultura tardomoderna. Proporcionaria elementos para um senso de unidade e segurança existencial em um mundo incerto e ameaçador. Não apenas seguiríamos estilos de vida, mas somos obrigados a fazê-lo - não há escolha senão escolher - qualquer coisa que seja. Não há como viver 
atualmente sem estar constantemente escolhendo diante das várias opções sucessivas que se nos apresentam ao longo do dia. Vive-se em um mundo de múltiplas escolhas - para aqueles que podem atuar como agentes de consumo.

Um estilo de vida pode ser entendido como um conjunto relativamente integrado de práticas individuais que estão voltadas para necessidades utilitárias e que conformam narrativas identitárias próprias. Além do 'como agir', refere-se a 'quem ser'. Tais práticas consistem em ações aparentemente automáticas relativas a hábitos de comer, vestir-se, formas de morar, modo de deslocar-se espacialmente, lugares a freqüentar etc. Em uma perspectiva elitizada, pode incluir padrões relativos a idéias de um 'bom-gosto'. Mas o estilo de vida não costuma estar acessível a não-consumidores: depende das possibilidades de acesso e de aquisição à variedade de opções disponíveis (Giddens, 1991).

Para Sousa Santos (2000), há duas tensões nas múltiplas linhas de construção da identidade (subjetividade). A primeira tensão está entre a subjetividade individual e subjetividade coletiva (há hegemonia da primeira); a segunda tensão, entre uma concepção concreta contextual da subjetividade e uma concepção abstrata genérica, a primazia é dada à segunda. Não parece despropositado considerar que as idéias carreadas pela noção estilo de via (entre outras no campo da saúde promocional) parecem se afinar bem mais com ambas perspectivas hegemônicas apontadas pelo sociólogo luso.

A partir da ótica individualista, interessam, no interior do dito estilo de vida de cada um, aquelas 'escolhas' e comportamentos com repercussões nos respectivos padrões de adoecimento das pessoas. No campo da cultura de consumo contemporânea, os aspectos perniciosos decorrentes de elementos que conotam "individualidade, auto-expressão e uma consciência de si estilizada. $\mathrm{O}$ corpo, as roupas, os entretenimentos de lazer, as preferências de comida e bebida, a casa, o carro, a opção de férias etc. (...)" (Featherstone, 1995: 119).

No entanto, tais opções não devem ser vistas como fruto de disposições intencionais, racionais, voluntárias. Cada um de nós é a resultante singularizada de complexas configurações bioquímicas, psicológicas, socioculturais, em que o estabelecimento e as tentativas de reordenação da idéia de si mesmo são frágeis e dependem de contribuições genéticas, aspectos epigenéticos, biografia pessoal, estrutura psicológica inconsciente, elementos culturais, acasos.

Portanto, os 'estilos de risco', são, a rigor, aspectos que, muitas vezes, participam e constituem os modos possíveis com que se lida com o mundo da vida tal como se faz presente a cada um de nós. Claro que determinados 'estilos' são perigosos, seja para o próprio indivíduo, seja também para os que o cercam. Assim, demandam intervenções apropriadas. Mas é essencial não perder de vista a perspectiva descrita, sob o risco de serem adotadas premissas que conduzam a ações insensíveis, culpabilizantes, limitadas e, conforme o caso, de efetividade restrita (Castiel, 1999).

Para Featherstone (1995), a noção estilo de vida está na moda. Ele pretende desenvolver uma abordagem que vai além da perspectiva de estilo de vida equivaler basicamente a padrão de consumo, manipulado pela chamada cultura de consumo de massa. Ou, então, que 
consista em uma categoria bem demarcada, com um domínio autônomo, além dos mencionados efeitos manipulativos. Neste caso, o conceito de habitus de Bourdieu (1989) permitiria melhor entendimento. Featherstone descreve as disposições determinantes dos gostos que definem cada grupo social. Inclui elementos inconscientes, padrões classificatórios, predileções (explícitas ou não) relativas à idéia que o indivíduo faz de seus gostos e escolhas estéticas - arte, comida, bebida, indumentária, entretenimento etc., e de sua validade e valorização social. Mais ainda: está 'encarnado' na própria apresentação corporal de si mesmo - forma e relação com o próprio corpo, fisionomia, postura, linguajar, padrões discursivos, modos de gesticular, andar, sentar, comer, beber etc. Cada grupo, classe e fração possui um habitus/estilo de vida próprio (Featherstone, 1995).

Em determinados segmentos sociais, mais favorecidos em termos socioeconômicos, o estilo de vida se dirige ao corpo como um bem, cuja aparência de vigor físico e juventude deve ser mantida. A idéia de boas condições de saúde se funde à de atratividade sexual. Esta conjugação gera uma grande estrutura industrial e comercial voltada ao mercado de cosméticos, vestuário, esporte, lazer, alimentação etc.

Mais uma abordagem que representa a perspectiva culpabilizante foi desenvolvida por Beaufort (1996), que define, em termos genéricos, o estilo de vida como sendo "o produto de escolhas sistemáticas, valores, metas e prioridades muitas vezes orientadas por princípios subjacentes ou objetivos que unificam escolhas particulares sobre o modo como levar a vida" (Beaufort, 1996: 47).

Para esta autora, um estilo de vida consiste em algo 'mais ou menos' (p. 47) escolhido livremente: 'mais livremente' - no caso de pessoas, que se auto-examinam sistematicamente e avaliam suas ações e comportamentos, deliberadamente e com cuidado (em termos implícitos, indivíduos responsáveis), seja referente à carreira profissional, matrimônio, momento conveniente de gerar filhos, incluindo o fato de conscientemente escolherem adotar o tabagismo ou não; 'menos livremente' - no caso de pessoas que 'vão na onda'. Conforme seu meio social, as decisões são casuais, pois suas vontades e respectivas decisões em relação, por exemplo, à carreira, matrimônio e época de procriar não partiriam de auto-análise e juízos criteriosos.

Mas ainda existem casos em que, por motivos de privação econômica e exclusão social, não há possibilidade de escolha. Nestas situações, não faz sentido considerar as pessoas responsáveis por seus estilos de vida. Mesmo assim, há perceptíveis conotações moralistas neste enfoque. Se não há carências em termos extremos de autonomia, pairam juízos de valor em que o padrão mais aceitável é o do agente racional que avalia, pesa e decide suas ações em termos teoricamente objetiváveis sob a égide de cálculos de custo-benefício.

Ainda: o estilo de vida seria uma mescla própria a cada indivíduo, constituindo-se em dois aspectos: 'orientações centrais (core)' e 'atividades periféricas'. Determinadas escolhas de estilo de vida seriam função da personalidade individual, ao passo que outras, menos importantes, não seriam. Apesar das dificuldades de definir estas categorias com nitidez, referem-se a valores sociais e a características econômicas e institucionais próprias às ditas 
democracias ocidentais avançadas no que se refere à relação com o emprego, com o lazer e com a vida familiar.

No entanto, do mesmo modo que tal padrão de referência normativa contorna estados de precariedade social, também encara determinados hábitos sob um ponto de vista disfuncional que ultrapassa os dois aspectos referidos anteriormente: é o caso das adicções. Mesmo levando em conta que certas substâncias podem participar da produção de dependências farmacológicas, as possibilidades adictivas da nossa época transcendem qualquer propriedade química de certas drogas. Nestas circunstâncias, o fato de algo adquirir caráter adictivo para algumas pessoas e para outras não pertenceria ao campo das variações individuais. Visivelmente, aqui não se discutem as fortes pressões obsedantes da cultura de consumo vigente, mas sim a ênfase no processo de decisão responsável quanto ao hábito de fumar ou à necessidade do uso de preservativos.

É importante considerar estudos em que se descreve como os discursos de estilo de vida e risco aparecem nas crenças de atribuição de causas ao adoecimento por parte de individuos que passaram por experiências de ameaça à sua saúde. Estabelecer tais 'razões' é uma das tarefas essenciais que indivíduos utilizam nas tentativas de reordenação subjetiva após eventos traumáticos graves desta ordem.

Um estudo realizado na Inglaterra pretende explicitamente superar as limitações de propostas quantitativas reducionistas na investigação das crenças de atribuições de causas ao infarto de miocárdio. Sua crítica se dirige às perdas de informação de tais propostas de pesquisa em termos da amplitude narrativa das explicações causais dadas pelas pessoas.

As pesquisas quantitativas, ao reduzi-las a categorias simples, fazem com que se perca o raciocínio subjacente que sustenta as justificativas das crenças. Ao desconsiderar tais argumentos e, também, o contexto em que estes ocorrem, quaisquer 'inferências' podem se mostrar insatisfatórias (French, Maissi \& Marteau, 2005). Uma revisão sobre estas pesquisas mostrou que, em 47 artigos e informes sobre crenças de atribuição causal sobre doença coronariana (French et al., 2001), as prevalências mais freqüentes no conjunto estudado eram estresse crônico (quase 41\%) e fatores de estilo de vida (quase 30\%).

No estudo qualitativo em foco, usando entrevistas semiestruturadas, abordou-se o primeiro infarto de miocárdio ocorrido recentemente. Os resultados apontaram para os seguintes tópicos: muitos entrevistados estavam buscando ativamente 'razões' causais para seu recente infarto de miocárdio; as atribuições mais freqüentes eram feitas ao estresse, à hereditariedade e a comportamentos não-sadios relativos a tabagismo, dieta e exercício físicos; causação necessária ao infarto de miocárdio como sendo de fonte única, ao invés de múltipla; supostas causas como fatores desencadeantes, ao invés de disposições subjacentes; evitação da culpabilização, seja de si mesmo ou de outros, pelo evento, ao mesmo tempo em que se procura assumir controle das situações de risco para evitar um possivel futuro infarto de miocárdio.

Neste estudo, há inegáveis boas intençoes em superar o 'reducionismo quantitativo'. Os autores discutem, no método qualitativo empregado, possiveis vieses e a pequena amostragem 
(12 indivíduos que foram entrevistados por seu primeiro infarto de miocárdio de um total de 22 que foram internados) em um hospital de fevereiro a novembro de 1998. Ainda assim, do texto emana um maldisfarçado afã de legitimação do estudo, ao enunciar garantias de qualidade em termos de produção de evidências para se fazer 'inferências'. Além do fato de esta pretensão parecer despropositada em um estudo com tais características, há afirmações bastante discutíveis, como a que se inclina para um aparente movimento de 'culpabilização dos culpabilizadores':

a prevalência de tentativas de evitar a culpa e assumir o controle (...) sugere que as atribuições feitas parecem ser adaptativas para as pessoas que as fazem. Pessoas que fazem atribuições de culpa e experimentam falta de controle tendem a ter pior ajustamento emocional depois de eventos adversos inesperados'. (French et al., 2001: 1420)

Vale ainda salientar outra tentativa de ordem teórica e conceitual que procura ir além das proposições conservadoras de demarcação do estilo de vida ao estabelecer uma referência básica na noção de 'modo de vida'. Tal proposta tenta ultrapassar o foco no comportamento dos indivíduos, a partir da ênfase na história das classes sociais marcada pelas relações sociais mais abrangentes, tendo um cenário marcado por sistemas de poder, organizados em termos de modos de produção e de definição de propriedade, incorporando elementos simbólicos e socioculturais da vida cotidiana (Almeida-Filho, 2000).

Sem dúvidas, uma crítica comum ao conceito de estilo de vida (e também à noção de 'autonomia') é referente a seu emprego em contextos de miséria e aplicado a grupos sociais em que as margens de escolha praticamente inexistem. Muitas pessoas não escolhem o estilo da vida que levam. Na verdade, não há opções disponíveis, apenas estratégias possíveis de sobrevivência.

Não é objetivo deste texto desenvolver a complexa temática relativa à discussão do estilo de vida como expressão de autonomia. O tópico 'autonomia', caro aos terrenos bioéticos principialistas, mas que se estende por âmbitos políticos e sociais, tem um significado mais abrangente que diz respeito à capacidade humana de produzir as leis para a autogestão e, também, de compartilhá-las com os demais humanos. Inclusive, há diversas tradições filosóficas abordando o problema.

Agora, cabe ainda mencionar a polissemia que 'autonomia' sofre. Refere-se a conceitos que expressam idéias que englobam privacidade, vontade, auto-suficiência, autocontrole, liberdade de escolha, autogoverno (com responsabilidade pela escolha). É preciso distinguir a 'autonomia' em termos de pessoa/ações, graus e condições de autonomia (intencionalidade, compreensão, ausência de controles externos).

Sentidos relacionados à autonomia dependem do entendimento vigente sobre a pessoa - em termos absolutos ou relativos. Importa enfatizar que a noção de autonomia está vinculada à idéia que se tem de ser humano/sujeito, de forma a delimitar: 'quanto' se é 
determinado biologicamente/geneticamente ('natureza humana'), 'quanto' se é construído nas relações sociais, em termos situados historicamente ('condição humana'). Geralmente, as concepções da promoção em relação ao comportamento humano não se definem com a clareza necessária diante do dilema 'livre-arbitrio versus determinismo'.

As propostas hegemônicas da saúde promocional se orientam por uma ciência epidemiológica que costuma reduzir a realidade da saúde ao individual e a visão ontológica da doença ao universo dos fenômenos empiricamente observáveis e ao registro unidimensional de uma ordem mecanicamente articulada por leis determinísticas (Breilh, 2003). Para ultrapassar tais leituras, vale destacar os estudos desenvolvidos por Frohlich et al. (2001, 2002), que procuram considerar, de modo ampliado, as relações entre contexto e padrões de adoecimento. Desenvolvem o promissor conceito de "estilos de vida coletivos", a partir da teoria da ação social, de Pierre Bourdieu; da teoria da estruturação, de Anthony Giddens; e da teoria das capacidades, de Amartya Sen.

Os estilos de vida coletivos emergiriam a partir de uma concepção recursiva da relação entre estrutura social e práticas sociais dos agentes que produzem e reproduzem gostos, valores e comportamentos. Seria a expressão de um modo compartilhado de se relacionar e atuar em dado ambiente - uma forma de metaestilo de vida (Frohlich, Corin \& Potvin, 2001). Os estilos de vida coletivos refletiriam os contextos em que vivem as pessoas através das suas relações com elementos do local, levando em conta que as ações do indivíduo guardam semelhanças com as dos que lhe estão próximos em termos de suas práticas sociais.

Ao mesmo tempo, os estilos de vida coletivos não apenas incluiriam comportamentos de saúde, mas também tentam reconhecer que tais condutas podem ocorrer em contingências sociais que diferem entre indivíduos. A ênfase se dirige às formas complexas de interação entre comportamento individual, comportamento coletivo e conjuntos de recursos existentes nas comunidades.

Os autores utilizaram este enfoque para desenvolver estudos sobre tabagismo em préadolescentes em quatro comunidades de Quebec, no Canadá. Os estilos de vida coletivos procuram integrar a situação socioeconômica, os recursos das comunidades em relação ao tabagismo e as práticas sociais das pessoas diante do hábito de fumar. Entre outras observaçoes, consideram a necessidade de os programas educativos integrarem os significados locais do tabagismo às estratégias para reduzi-lo (Frohlich et al., 2002).

No campo da saúde, 'estilo de vida' é uma categoria onipresente nos terrenos da promoção, prevenção e da pesquisa das relações entre aspectos socioculturais e a saúde. Entendimentos descontextualizados do estilo de vida em seu formato individualista são insuficientes para representar satisfatoriamente as determinações e intermediações envolvidas nas questões que se relacionam com 'comportamentos de risco', no nivel individual, e medidas de promoção e prevenção em termos populacionais. 
É importante ter em conta que, para compreender o contexto sociocultural, a epidemiologia lança mão de técnicas de investigação utilizadas na saúde pública, denominadas análise multinível (Diez-Roux, 2002).

Tais técnicas procuram abordar dados que envolvem unidades em um nível de organização mais baixo (por exemplo: indivíduos) incluídas em um nível mais elevado (como bairros, vizinhanças, escolas). Este tipo de análise permite a abordagem conjunta dos efeitos das variáveis no nível do grupo e no nível do indivíduo, ao mesmo tempo que leva em conta a não-independência das observações entre os grupos. Isto pode ocorrer quando variáveis dependentes relacionadas a observações em nível mais baixo estão correlacionadas, mesmo depois que características mensuradas foram devidamente levadas em conta - por exemplo: adolescentes com hábitos de fumar equivalentes por pertencerem à mesma vizinhança em comparação com jovens de vizinhanças diferentes. Além disso, análise multinível permite estudar a variabilidade entre os grupos e no interior dos grupos e como a variabilidade em indivíduos e grupos se relaciona (Diez-Roux, 2002).

Em termos abreviados, sob esta perspectiva, podem-se realizar análises contextuais para dimensionar os efeitos de componentes do nível coletivo ou grupal em desenlaces no nível dos indivíduos. Este enfoque faculta a análise conjunta das variáveis grupais e individuais que estão relacionadas aos desfechos em indivíduos. Os resultados encontrados podem indicar 'efeitos' 'contextuais' ou 'composicionais' (Diez-Roux, 2002).

Esses últimos são aqueles atribuíveis a diferenças na composição dos grupos. Por exemplo, as taxas de tabagismo em um bairro podem ser atribuídas a características dos indivíduos que constituem os grupos. Nas circunstâncias de efeitos contextuais, tais efeitos das variáveis especificadas em um nível mais elevado (grupal) atuam sobre desfechos localizados em nível mais baixo (individual), depois do controle de fatores de confundimento (confounding). Por exemplo, facilidades de acesso a maços de cigarro em bares e quiosques de um bairro e tabagismo em adolescentes nessa área.

É sabido que existem efeitos do contexto de vizinhança/bairro que podem ser importantes no estado de saúde das pessoas que aí vivem. Tais efeitos, em países desenvolvidos, podem se manifestar através do grau de disponibilidade e acesso a recursos assistenciais, privação de dispositivos de infra-estrutura, prevalência de determinados comportamentos de saúde, estresse e falta de suporte social (Pickett \& Pearl, 2001). No caso de países do terceiro mundo, as condições precárias de vida, per se, já são suficientes para explicar as grandes insuficiências em saúde.

Na detalhada revisão crítica sobre análises multinível entre o contexto socioeconômico de vizinhanças ou bairros e desfechos em saúde, Pickett e Pearl enfocaram 25 pesquisas sobre vários desfechos em termos de mortalidade, morbidade e comportamentos de saúde. Dos sete estudos deste último tipo, cinco tratavam de tabagismo como desfecho primário. Destes cinco, quatro, que avaliavam os efeitos dos fatores sociais no hábito de fumar, identificaram 
riscos relativos de fumar entre 1,2 e 1,7 em áreas com baixo nível socioeconômico (sendo possivel haver influência de aspectos de gênero e raça como se observou em um dos estudos).

Dos 25 estudos, em 23, os pesquisadores descreveram associações estatisticamente significativas em, pelo menos, uma medida de condição socioeconômica e saúde - efeito contextual, controlando as condições socioeconômicas individuais - efeito composicional. Eles assinalam que os efeitos contextuais foram, em geral, pequenos, menores que os efeitos composicionais. Em síntese, a atribuição de diferenças na saúde devidas ao contexto social da vizinhança/bairro demanda a discriminação da influência socioeconômica no nível individual. Em poucos casos, a definição operacional de 'vizinhança' (em países desenvolvidos) obedeceu a delimitações 'naturais'. Os achados sinalizam que os contextos das vizinhanças podem afetar diferentemente a saúde das pessoas, mesmo que se apresentem em equivalentes baixas condições socioeconômicas. ${ }^{23}$

Um esclarecedor exemplo que apresenta de forma sinóptica e irônica os extremos das propostas de promoção de estilos de vida saudável em relação ao contexto dos países economicamente avançados foi elaborado por Edwards (2005). Consistem em 'dicas' comparativas para a boa saúde - a partir de uma perspectiva de estilo de vida e do ponto de vista dos determinantes sociais da saúde. Vale a pena conhecer algumas:

Estilo de vida:

$\triangleright$ Não fume. Se puder, pare. Se não puder, reduza.

$\triangleright$ Siga uma dieta equilibrada e suficiente em frutas e vegetais.

$\triangleright$ Mantenha-se fisicamente ativo.

$\triangleright$ Administre o estresse, por exemplo, conversando sobre o que lhe aflige (talking things through) e buscando tempo para relaxar.

$\triangleright$ Se ingerir álcool, faça-o com moderação.

$\triangleright$ Proteja-se e às crianças das queimaduras do sol.

$\triangleright$ Pratique sexo seguro.

Determinantes sociais de saúde:

$\triangleright$ Não seja pobre. Se puder, pare. Se não puder, tente não ficar pobre por muito tempo.

$\triangleright$ Não tenha pais pobres.

$\triangleright$ Seja proprietário de veículo.

$\triangleright$ Não trabalhe em atividades estressantes e mal pagas.

${ }^{23}$ Para um maior aprofundamento nos estudos multinivel, ver: Diez-Roux (2002). Trata-se de uma introdução ao significado de termos úteis de análise multinivel, a partir de uma perspectiva de investigação em epidemiologia social. 
$\triangleright$ Não resida em moradias úmidas, de baixa qualidade.

$\triangleright$ Tenha condições econômicas para sair de férias e tomar banhos de sol.

$\triangleright$ Pratique não perder seu emprego e ficar desempregado.

Sob o ponto de vista sociológico, Giddens (1979) formulou uma hipótese digna de atenção para pensar certas características compulsivas do estilo de vida próprio às sociedades do capitalismo avançado (mas também com repercussões nas nações ocidentais economicamente menos privilegiadas). O sociólogo inglês analisa o papel repetitivo dos costumes, rituais e cerimoniais coletivos (em geral, de cunho religioso) nas sociedades ditas tradicionais ou fundamentalistas para a constituição de identidades culturais estáveis dos seus indivíduos.

Tais tradições heterônomas devem prosseguir na medida em que continuarem sendo sustentadas e legitimadas em sua capacidade de produção de subjetividades em modalidades de laços sociais e de modos de ordenação social. Nas sociedades cosmopolitas ocidentais, há um significativo recuo no papel das tradições e enfraquecimento de rituais coletivos. Predominam formas consideradas mais autônomas, dinâmicas e individualistas de construir identidades plásticas e, portanto, cambiáveis ao longo das trajetórias em aberto da vida.

Ora, para este formato identitário de caráter instável, a idéia de 'escolher' estilos de vida dentro do 'menu' sociocultural dominante se constitui um convite arrebatador. Atua como eixo na constante busca de auto-ordenação disponibilizada pelos ambientes vigentes, onde há proliferação de bens e mercadorias no âmbito da produção, alta circulação no setor de distribuição e inevitáveis frenesis no pólo do consumo.

O efeito adverso desta configuração localizar-se-ia no que Giddens chama "autonomia congelada": geração de múltiplos e incessantes rituais individuais que se manifestam como dependências. Há uma epidemia de excessos: estados obsessivo-compulsivos, variados tipos de dependência e de adicções, dificuldades em estabelecer limites e aderir a regras. Se nas sociedades heterônomas, tradicionais, o passado estrutura o presente através de crenças e rituais compartilhados, nas sociedades autônomas, diferentemente do que sugere Giddens (1979: 57), o dependente não estaria escravizado ao passado "por não escapar do que originalmente eram hábitos de EV livremente escolhidos”, mas por estar prisioneiro de um presente que não cessa de se reconfigurar em forma de uma espiral onde prevalece a obrigação de usufruir da liberdade de escolher um frágil vetor identitário constituído pelos estilos de vida, tomando, à medida do possível, muito cuidado para não fazer escolhas insalubres.

Infelizmente, a saúde promocional, em suas formulações científicas hegemônicas, não costuma dedicar a necessária atenção em relação a dimensões socioculturais cruciais e a questões relativas a seus fundamentos filosóficos. Como conseqüência, sofre de graves tensões teóricas que a fragilizam grandemente. Seus conteúdos acabam afetados por afirmações cujo significado ou é ilimitado, ou é destituído de sentido, ou, quando há algum sentido, este é bastante restrito (Seedhouse, 1997). 



\section{Genômica, Epidemiologia e Saúde Pública}

Antes de prosseguir, um comentário que, dado a sua reiteração, quiçá se mostre supérfluo, mas, para efeitos de busca de efetividade discursiva ao se transitar nos limites da responsabilidade, é essencial não deixar dúvidas. É importante esclarecer que não se trata de fazer uma crítica irresponsável a indiscutiveis benefícios veiculados pelos avanços dos conhecimentos genômicos e de suas aplicações, mas de assinalar possiveis insuficiências em termos éticos e sociais, para que tais limitações sejam reconhecidas, enfrentadas e superadas.

Ainda, é essencial considerar que as pesquisas genômicas abordam eventos multidimensionais encadeados em vários níveis, tanto em termos verticais como horizontais, que se transformam com enorme rapidez em função da alta aceleração dos domínios biotecnológicos, onde se mesclam fortes interesses variados de diversos indivíduos e instituições, públicas e privadas (Kaufert, 2000).

O termo genômica teria sido criado em 1987. Designa um modo de lidar com as questões do genoma ${ }^{24}$ - palavra que teria sido usada pela primeira vez em 1920 e que se originou de uma fusão das palavras 'gene' e 'cromossoma' e descrevia apenas um dos aspectos do campo da genética (Scriver, 2004). Este aspecto cresceu e se tornou independente do campo de onde se originou ao tornar-se ele próprio um domínio disciplinar e, agora, ocupa progressivamente o terreno no qual surgiu.

\footnotetext{
${ }^{24}$ Seria interessante uma incursão entre 0 que foi antes exposto como sensibilidade epistemológica e os conceitos de genômica como disciplina, gene como conceito e até mesmo com a própria noção de DNA. Com freqüência, anuncia-se o seqüenciamento completo de um genoma. Estas notícias nas revistas científicas lembram muito a clássica primeira página dos livros de Asterix, o gaulês, de Goscinny e Uderzo aquelas em que, depois de um enunciado imperialista e totalizador: "toda a Gália está ocupada pelos romanos", se fazia a crítica pergunta: toda? 0 genial desenho de Uderzo usava uma grande lupa para que víssemos melhor, com mais clareza, e nos déssemos conta de que a sensibilidade epistemológica do enunciado era limitada, e que havia uma clara intenção ideológica por detrás daquele erro imperialista.

Da mesma forma que nem toda a Gália estava ocupada pelos romanos, não podemos pensar, nem sequer afirmar, como costumamos, que conhecemos totalmente a estrutura dos genes. Assim como a aldeia de Asterix e Obelix se mantinha à margem, uma vez que os romanos até a eles chegaram, viram-nos, mas não
} 
Se esta sinopse veicula algo do conhecido tema da criatura que subjuga seu criador, há especificidades que merecem ser consideradas. Se os antigos terrenos da genética ficaram incomodamente marcados por notórios estigmas eugênicos, uma das formas de se livrar desta pecha seria, de alguma forma, procurando se desvincular destas marcas. A genômica é a nova genética, que seria essencialmente distinta da velha por afastar-se, em tese, da intimidade desta última com notórias e trágicas propostas totalitárias de purificação eugênica (Peterson \& Bunton, 2002).

Os estágios do desenvolvimento da genômica desde finais dos anos 80 podem ser descritos da seguinte forma: a) criação de instrumentos para o mapeamento do genoma humano; b) a localização e identificação de genes-'chave'; c) seqüenciamento de genomas, em especial do genoma humano; d) o exame das relações genótipo/fenótipo em doenças multifatoriais complexas; e) a avaliação dos supostos determinantes genéticos da saúde nas populações ou genômica populacional (GP).

A capacidade de difusão da genômica é muito intensa e veloz. Inevitavelmente, ocorreu a aproximação com disciplinas e campos de pesquisa pertencentes à saúde pública e à epidemiologia. Com isto, assistimos à aparente consumação de uma aproximação progressiva que teria se delineado com a chamada 'epidemiologia molecular' do início dos anos $90 \mathrm{e}$ que agora assumiria um novo patamar com a GP. Este novo patamar teve um momento inaugural com a criação da HuGE Net (Human Genome Epidemiology Network), em

os venceram, não conhecemos nem muito menos, nem sequer em sua maior parte, o que venha a ser um gene. Toda a genômica atual se baseia no conhecido achado de Dawson e Danielli em 1929. Eles viram como 'uma parte' do conteúdo genético se organizava em uma hélice, desde então e com uma arrogância que somente os biólogos sabem ter, ao resto se denomina 'DNA lixo' (junk DNA). Sempre se soube que o DNA lixo consiste em uma considerável parte do que possuímos e possuem os seres vivos, e os estudos do Projeto Genoma foram aumentando cada vez mais tal proporção. Na atualidade, para a maioria dos seres vivos, se aceita que seja mais que 90\%. Quando se pergunta a um genomista sobre a função deste material, é comum que alegue candidamente que não tem função, que esses genes estão aí porque são restos da evolução. Tão apegada ao método experimental como é a biologia, é, pelo menos, chocante que se aceite esta ordem de afirmação sem prova experimental disto.

No entanto, desde suas origens, a genética tem problemas de pouco rigor na comunicação de seus achados. Já sabemos que Mendel literalmente inventou suas famosas leis das ervilhas lisas e rugosas. Federico di Trocchio, em seu livro Las Mentiras de la Ciencia.¿Por Qué y Cómo Engañan los Científicos? (1995) propõe, inclusive, o uso da palavra enganologia para definir esta atividade que ele considera como estrutural: "La engañología es la ciencia que enseña a los científicos cómo engañar a otros científicos. Estos, a su vez, convencen a los periodistas, quienes finalmente se encargan de seducir a las masas. (...). El objetivo real lo constituyen los científicos que forman parte de los organismos estatales que financian la investigación y que son los que tienen el poder de decidir qué estudios y qué investigadores deben obtener la ayuda económica y a cuánto debe ascender". Os geneticistas estão cada dia mais interessados na 'epigenética' e no 'imprinting genético', isto é, no estudo dos efeitos dos genes que não estão geneticamente determinados no sentido mendeliano. 
1998, que deu início a um esforço de colaboração entre indivíduos e instituições voltados à avaliação dos efeitos das variações do genoma humano na saúde das populações. Uma função desta rede foi produzir protocolos, recomendações e técnicas de verificação e incorporação de informações epidemiológicas acerca do genoma humano, desde a pesquisa primária em genômica até a disseminação para efeitos de política e práticas, por exemplo, em relação 'a produção de testes genéticos' (Khoury et al., 2004).

As metas dos mega-empreendimentos desta nova faceta epidemiológica na atualidade se dirigem para ampliar o conhecimento das bases genéticas do desencadeamento, da evolução e da resposta aos tratamentos de muitas doenças. O propósito unificador de tantas e diversas atividades tende a ser enfeixado sob a égide da melhoria dos recursos preventivos, diagnósticos e terapêuticos (Palmer, 2004).

Mais especificamente, no caso das doenças infecciosas, por exemplo, o seqüenciamento dos genomas de agentes microbianos patogênicos pode proporcionar informações essenciais para construir testes diagnósticos, detectar mecanismos de virulência e determinar as formas de escapar da ação das defesas dos hospedeiros. Pelo lado destes últimos, os estudos genômicos podem trazer mais conhecimento às variações de suscetibilidade e das reações às infecções humanas. Estes elementos podem gerar condições de possibilidade para a produção de vacinas efetivas para doenças como a Aids, a tuberculose, a malária, entre outras. As pesquisas do genoma podem trazer melhor entendimento dos mecanismos imunológicos envolvidos nos respectivos processos moleculares etiopatogênicos e viabilizar a criação de vacinas ou antibióticos mais efetivos (Chokshi \& Kwiatowski, 2005).

No entanto, diante de enfermidades genéticas (mas também crônico-degenerativas), são vigorosos os discursos de responsabilização pessoal. Citamos, como exemplo, o caso da Genzyme, uma empresa norte-americana de biotecnologia. Em seu site, a empresa faz questão de ressaltar a responsabilidade genética de pais judeus de ascendência ashkenazi com vistas a conhecer mediante testes genéticos a constituição gênica dos filhos em função do risco de doenças genéticas prevalentes nesta população. Ainda que assumindo os potenciais interesses econômicos que subjazem aos intentos educativos de uma empresa nestes moldes, é importante perceber a atmosfera culpabilizadora em que esta argumentação ocorre.

Os conteúdos de caráter explicativo encontrados no site da Genzyme (〈www.genzymegenetics.com/patient/conditions/gene_p_patient_conditions_AJ.asp〉) são exemplos bastante significativos. O título "Conhecer sua herança (genética) é apenas o começo" se refere à responsabilidade dos judeus de origem ashkenazi de se submeterem a testagens genéticas para o diagnóstico preventivo de doenças genéticas nos respectivos filhos. Ou seja, parte de uma retórica epidemiológica que evidencia maiores riscos deste grupo a determinadas doenças genéticas (fibrose cística, doença de Tay-Sachs, doença de Canavan, síndrome de Bloom, disautonomia familiar, anemia Fanconi - grupo C, doença de Gaucher - tipo 1, mucolipidose tipo IV, doença de Niemann-Pick - tipoA). Além disto, se explicita 
que 'conhecer sua herança (genética) é apenas o começo', supostamente, o começo da responsabilidade pessoal com a saúde dos filhos antes mesmo que sejam concebidos.

Há informes de fontes insuspeitas que procuram trazer esclarecimentos sobre as atuais condutas públicas de screening em tais afecções, aparentemente diante de pressões para se realizar testes genéticos para estas enfermidades a partir da existência, desde os anos 70, de screening somente para a doença de Tay Sachs. Por exemplo, o relatório de um encontro, em junho de 2004, para o Comitê Nacional de Screening, realizado no Guy's Hospital de Londres, assinala a necessidade de mais estudos para as demais doenças, como as que constam do portal mencionado, com ênfase variável em termos de prioridades de umas em relação às outras, com mais destaque para a disautonomia familiar e para a doença de Canavan (Levene, 2004).

De qualquer forma, não é absurdo cogitar que a disponibilização progressiva de testes genéticos, aliada ao clima de responsabilização pessoal, pode elevar as pressões para a realização de tais exames diagnósticos. Vale assinalar que a responsabilização de parentes consangüíneos em relação aos descendentes em relação a doenças crônicas pode, até mesmo, se ampliar, passando a responsabilizar os avós por doenças desenvolvidas pelos netos.

Um indício dessa possibilidade aparece em um estudo divulgado nos meios de comunicação de massa. Trata-se de uma investigação de caso-controle, aninhado em um estudo maior (Chidren's Health Study no sul da Califórnia) que buscou verificar a associação entre asma infantil e o hábito de fumar da mãe e da avó, antes, durante e depois da gravidez. Chegou-se à conclusão de que o hábito de fumar da mãe e da avó estava associado ao aumento do risco de asma infantil. $\mathrm{O}$ estudo inclui a possibilidade de intervirem fatores genéticos nesta vinculação (Li et al., 2005).

Para além dos discursos bem justificados ou não que explicitam e sustentam a racionalidade biocientífica dos grandes empreendimentos de investigação genômica e de produção de tecnologia, podem-se perceber certos deslocamentos retóricos que acompanham estes movimentos. Não faltam autores, em respeitadas publicações científicas do âmbito da saúde pública e da epidemiologia, para enfatizar a 'revolução genômica' em várias áreas da produção do conhecimento e das práticas em saúde, transformando-as, inapelavelmente.

Tampouco cessam de surgir novos substantivos e adjetivos que procuram designar parcerias e hibridizações, disciplinares ou não, com vistas a integrar conteúdos provenientes da combinação de múltiplos setores de investigação epidemiológica, genética, pesquisa clínica, sob a forma de projetos públicos, privados, acadêmicos, empresariais etc.

Um exemplo de novos substantivos se refere às novas subdisciplinas com o sufixo 'ômico', acompanhando a grande matriz 'genômica', e que se voltam a estudar os produtos, expressões e interações gênicas: 'proteômica', 'transcriptômica', 'metabonômica', 'nutrigenômica', 'farmacogenômica' (Khoury et al., 2004). Os adjetivos utilizam o recurso de adjudicar-se o 
predicado 'novo' a conhecidas disciplinas - a nova epidemiologia genética (Davey-Smith, 2004) que seria aquela que procura compatibilizar impactos recíprocos entre ambas disciplinas ou, então, assumir o surgimento da 'epidemiologia genômica' - outro nome para a genômica populacional ou para a epidemiologia do genoma humano.

A própria genômica consiste em um campo de efervescente geração de discussões. $\mathrm{Na}$ última década e meia houve uma proliferação de matérias, estudos, artigos, livros e relatórios sobre o tema, com um variado espectro de posições. Os pontos de vista que nos parecem mais proveitosos em termos críticos - propósito deste texto - são aqueles que procuram localizar sociologicamente as questões de responsabilidade emanadas a partir da chamada nova genética.

Mas, sem dúvida, proliferam aqueles que enfatizam posições individualistas, como o livro da Associação Médica Britânica (1998): Genética Humana: escolha e responsabilidade, em que se ressalta a necessidade de difundir informação com vistas à 'escolha informada' dos pacientes, de modo não-diretivo, de maneira a respeitar seus 'desejos' e 'necessidades' e, também, os de suas famílias em função de uma determinada noção de autonomia - algo que Petersen (2002) discute sob o ângulo do ideal de uma 'cidadania genética'.

Cabe fazermos uma breve escala para efeitos de reconhecimento de terreno dos domínios ideologicamente mais conservadores das ciências biológicas evolucionistas. Esta sumária incursão se deve à relevância das chamadas 'guerras biológicas' que se iniciaram com a publicação e difusão ao público dos trabalhos sociobiológicos de Edward Wilson em meados dos anos 70. Ele e seus seguidores ultradarwinistas travaram uma sucessão de polêmicas renhidas com biólogos (entre eles, Stephen Jay Gould, Richard Lewontin e Steven Rose) que não aceitavam as teses que definiam geneticamente as características subjetivas dos seres humanos. Esta luta não chegou a seu final e um de seus muitos artefatos é a obra que vamos comentar a seguir. 



\section{Genes e Comportamentos em Saúde: em busca de informes responsáveis}

Dois acadêmicos de Harvard - Terry Burnham, professor de Economia, e Jay Phelan, de Biologia - produziram a obra A Culpa é da Genética, cujo título original é Mean Genes (Genes Perversos) (Burnham \& Phelan, 2002). Este livro consiste em um exemplo extremo das teses sociobiológicas dirigidas ao grande público. Sua tese nuclear é: somos constantemente possuídos por instintos ancestrais que tendem a comandar as ações das criaturas que lhes hospedam. Esses instintos atuam como se fossem demônios interiores, programados pelos nossos próprios genes. Estes, por sua vez, operariam como conspiradores endógenos, responsáveis por nossa 'insensatez', resultante de constantes crises da nossa incapacidade em estabelecer rédeas na busca de domínio de nosso 'eu racional' nas experiências da vida.

Tempos atrás, os genes não seriam nocivos para os humanos que se comportavam como caçadores coletores. Com mudanças socioculturais, muitas funções gênicas teriam se tornado desnecessárias e prejudiciais do ponto de vista evolutivo. Os genes fariam com que não tivéssemos limites em nossos desejos e na busca compulsiva por prazeres que se manifestariam em problemas como: dificuldade para economizar, ingestão incontrolada de alimentos, uso de drogas, exposição irracional a riscos, ganância, conflitos entre os sexos. Além disto, há explicações naturalizadas para a busca por beleza e juventude, para a infidelidade e para os ambivalentes laços familiares e interpessoais. Como conclusão, há um enaltecimento dos esforços para 'sobreviver a nossos desejos'.

Vale a pena assinalar que a referência comparativa dos sociobiólogos aos tempos dos caçadores/coletores parece sempre estar referindo-se aos períodos em que os elementos da cultura humana ainda eram incipientes. O paradigma caçador/coletor enfatiza a noção que a cultura teria desadaptado a humanidade de sua estrutura biológica, enfeixada pelos seus genes que, 'desajustados', se tornam 'perversos'.

A obra em foco recebeu considerável destaque em termos publicitários. Está dirigida ao público leigo a quem, ao final de cada capítulo, oferece conselhos, sugestões de auto-ajuda em termos de reforço da prudência e do comedimento das instâncias lógico-racionais para nos orientarem a evitar descaminhos e tentações desta civilização repleta de traiçoeiros atrativos oferecidos insistentemente. 
Como indicam os autores no início, trata-se de um 'guia do usuário para seu cérebro', pois este não se comportaria com um 'servo obediente'. Para isto, devemos evitar explicações propostas por Freud e nos ancorar nas leituras ultradarwinistas da biologia de modo a nos trazer uma construção científica da 'natureza humana'. Isto deverá servir para nos municiar em busca da salvação mediante o desarmamento das estratégias danosas dos genes perversos em nossas entranhas.

Talvez fosse possivel não levar a sério esta abordagem empobrecedora e por vezes caricatural do comportamento humano proposta pela genética evolucionista de linhagem sociobiológica em suas tentativas de estabelecer leis biocientíficas regentes do funcionamento humano. Porém, importa aqui ressaltar aspectos cruciais que, muitas vezes, não recebem a devida atenção. A ciência costuma ser encarada como uma instância separada da sociedade, mais do que como produto dela. Os conhecimentos da genética tendem a ser considerados como resultantes da busca objetiva dos cientistas pelas 'verdade dos fatos'.

Em geral, fora do âmbito acadêmico específico, está reduzida a discussão acerca das instabilidades e limitações dos dispositivos científicos na busca do conhecimento. E também são desconsideradas abordagens relativas aos modos como as ideologias influem nos encaminhamentos das atividades científicas: o que se define como questão científica, o que se convenciona como objeto de estudo, como são financiadas as pesquisas, como se fixam critérios que determinam a pretendida verdade de um fato, como se dá a difusão científica e comunicação pública dos achados. Sobretudo, importa estabelecer e distinguir quais são as relações entre poder e conhecimento nesta conturbada arena.

Além disto, é preciso levar em conta o fato de esta disciplina estar ideologicamente identificada com uma concepção da dinâmica social moldada no interior do liberalismo avançado globalizante e de seus valores individualistas de liberdade de escolha e consumismo. Nestas circunstâncias, é importante criar condições para que as pessoas se governem em função da referência a uma 'natureza humana ${ }^{25}$ e não diante da perspectiva de que humanos se tornam pessoas no processo de viver em sociedade.

Para os adeptos da via comportamental da sociobiologia, existe uma 'natureza humana' ou, melhor dizendo, uma 'condução' humana via genoma. Deste modo, genes adquirem

\footnotetext{
${ }^{25} 0$ biologicismo é uma ideologia que pretende utilizar premissas essencialistas dirigidas ao entendimento da matéria viva de modo a explicar o comportamento dos seres humanos nos registros psicológico e social. Esta ideologia se reveste de intencionalidade de modo a explicar o comportamento dos seres humanos nos registros psicológico e social. Basicamente, nem o discurso, nem os objetos de estudo dos atuais sociobiólogos se distinguem muito daqueles feitos, no século XIX, por morfologistas como Lombroso, que também apelou a diferenças na forma de cérebros de homens e mulheres, de homossexuais, adictos ao álcool, ou criminosos. Posteriormente, a mesma ideologia se aplicou tanto aos microorganismos como ao metabolismo. É interessante notar que as perguntas de investigação tenham ido sempre no mesmo sentido, ou seja, como a biologia determina a sociedade ou o comportamento, e que, aceitando esta proposição epistemológica, quase nunca se investigue no sentido inverso, isto é como a sociedade - a história social - determina a biologia.
} 
estatuto antropomórfico, podendo ser perversos ou bons, ou gays, criminosos, adictivos, entre outras qualificações.

Há forte sustentação acadêmica da sociobiologia na procura por estabelecer, há mais de três décadas, as bases genéticas do comportamento humano. É perceptível sua vigorosa inserção institucional em termos de produção de trabalhos, difusão acadêmica e divulgação para o público não especializado. Este último aspecto transparece na profusão de livros produzidos por vários pesquisadores: Edward Osborne Wilson (o patrono da sociobiologia), Steve Pinker, Richard Dawkins, David Buss, Jared Diamond (todos estes receberam agradecimentos formais dos autores de Mean Genes), entre muitos outros.

Mesmo no âmbito das ciências da vida, ainda não há elementos que corroborem o determinismo gênico do comportamento humano. Esta é uma das conclusões do relatório Genetics and Human Behaviour: the ethical context, do respeitado conselho de bioética britânico Nuffield Council on Bioethics (NCB) (2002), editado na Grã-Bretanha. O NCB é uma entidade inglesa criada em $1991 \mathrm{com}$ a finalidade de identificar examinar e produzir documentos com vistas a considerar dimensões éticas decorrentes dos desenvolvimentos na pesquisa em biologia e na medicina. Desde 1994, é financiada conjuntamente pela Nuffield Foundation, pela Wellcome Trust e pelo Medical Research Council.

O NCB lançou um minucioso relatório sobre tal temática. Ainda que nada exista de conclusivo sobre o determinismo gênico do comportamento humano, em função da ansiedade social vinculada a tais temas - especialmente sob o ponto de vista de práticas eugênicas (tanto no sentido negativo - de eliminar 'indesejáveis', como no positivo - de estimular a reprodução de 'desejáveis'), este oportuno documento apresenta um resumo de todo o texto com as recomendações para quem pretende não ler todo o material e suas tecnicalidades. Para os que desejarem se aprofundar, há 15 capítulos, distribuídos em quatro seções: 1) introdução - definição dos traços comportamentais normais e o contexto histórico das práticas eugênicas; 2) aspectos metodológicos da pesquisa em genética comportamental genética quantitativa (estudos de irmãos, de gêmeos, de crianças adotadas e famílias), genética molecular (exame de DNA em humanos para verificar variações em genes específicos) e estudos com manipulações de DNA em modelos animais; 3) revisões das evidências produzidas sobre traços de comportamento como inteligência, personalidade, comportamento anti-social e orientação sexual; 4) recomendações em termos éticos, jurídicos, sociais e relativos a políticas públicas.

Importa destacar a forma corajosa com que o documento aborda questões controversas e aponta para seus correspondentes aspectos inconclusos. Desde a definição do que sejam comportamentos normais - normalidade sob a ótica estatística (o que não resolve satisfatoriamente o problema, mas permite que a discussão não se interrompa), passando pelas tentativas e respectivas dificuldades em delimitar e medir objetivamente dimensões intrincadas, de limites bastante imprecisos como inteligência, personalidade, comportamento anti-social/ violência e orientação sexual. 
São discutidos tópicos explosivos, como seleção de embriões, riscos de medicalização do comportamento humano e possíveis impactos nos ordenamentos jurídicos e no ambiente educacional, securitário e laboral. São também feitas cruciais referências a questões relativas à liberdade e dignidade humanas. Em geral, o teor dos conteúdos apresentados, apesar das tecnicalidades, é esclarecedor, e o tom da argumentação, sensato.

A publicação chama a atenção para o fato de pesquisas em que se procuram demonstrar associações entre variantes genéticas específicas e traços comportamentais receberem destaque substancial nas mídias leiga e científica. Vale lembrar que os vários métodos de pesquisa neste campo não são infalíveis e que poucos estudos foram replicados com sucesso até o momento. Deve-se ter cuidado com os achados divulgados pela linha de pesquisa da genética comportamental, por serem potencialmente passíveis de conclusões enganosas.

Tal aspecto deve ser visto com atenção diante da possibilidade de estas narrativas e tecnologias genéticas se arvorarem, como mencionado, a desvendar contornos da natureza humana. Assim, serviriam como fonte de concepções de normalidade, indivíduo, sociedade, de modo a estabelecer critérios para a gestão biopolítica de lugares sociais e de intervenções e controles regulatórios de populações.

Em suma, esta é uma área atribulada da investigação em genética, repleta de controvérsias apaixonadas e extrapolações polêmicas. Há questões envolvendo a validade de alguns métodos de pesquisa. É difícil especificar e entender a ação dos fatores genéticos, assim como é árduo circunscrever e dimensionar os traços comportamentais. Ainda não é possível estabelecer correlações entre um simples gene e um traço comportamental, nem as interações complexas entre grupos de genes envolvidos na predisposição de um indivíduo possuir um traço em particular. É também complicado isolar a participação extragenética no comportamento e nos genes e influências genéticas na esfera dita ambiental (Castiel, 2002).

Com o avanço das técnicas da biologia molecular, em geral, e das manipulações genéticas, em particular, o campo dos conhecimentos em saúde coletiva passou a ter de lidar com o surgimento de uma possível abordagem genômica reducionista, para além das influências do meio-ambiente (Martin-Llaguno \& Álvarez-Dardet, 2000). Nestas circunstâncias, o foco principal das intervenções em saúde coletiva se voltaria para a abordagem genômica de 'indivíduos' e suas 'famílias' em detrimento de seu objeto consagrado - 'populações' -, deslocando, desta forma, a ênfase dos esforços (e recursos) sanitários para reduzir o adoecimento em função das desigualdades em termos socioeconômicos (Petersen \& Bunton, 2002).

Isto se torna especialmente relevante em função de desdobramentos no âmbito da 'genômica' - instituições envolvidas no conhecimento do DNA humano e de outros organismos biológicos, suas aplicações, patenteamentos e regulação, envolvendo organizações privadas de biotecnologia, seus empresários, administradores e pesquisadores. Tais empresas dedicam-se a atividades como: desenvolvimento de sondas de DNA, seqüenciamento de genomas de agentes patogênicos, identificação de genes e respectivas regiões regulatórias, venda de inscrições para acesso aos bancos de dados genômicos, produção e comercialização de kits com material 
para a pesquisa genética, identificação de genes de doenças com propriedades sinergísticas, rastreamento de amostras de DNA de indivíduos e famílias afetadas por doenças específicas (Cohen, 1997).

A importância econômica deste empreendimento pode ser aquilatada pelos vários vínculos das empresas genômicas com a indústria farmacêutica. Aliás, este aspecto merece alguns comentários. Primeiro, há estimativas que as companhias produtoras de drogas trabalham em centenas de potenciais 'alvos' farmacológicos, ou seja, enzimas, receptores, canais iônicos (não pertencentes a agentes patogênicos) que desempenham papel importante em determinadas doenças. Surge uma 'química combinatória', que permite a construção de grandes catálogos de potenciais drogas através de técnicas bioinformáticas de simulação. ${ }^{26}$ Segundo, surgem perspectivas farmacogenéticas de criação de drogas personalizadas. A compreensão das raízes genéticas das doenças permitiria descobrir suas relações com a constituição genotípica dos indivíduos. Com isto, devem surgir novos processos amostrais para a pesquisa clínica, agrupando os casos e controles segundo traços geneticamente demarcados. Assim, seria possível padronizar pacientes quanto à sua capacidade de responder ou não a determinadas drogas. Terceiro, surgem perspectivas de manipulações genéticas tendo como alvos doenças e comportamentos.

Um outro importante documento foi produzido pela agência canadense Policy Research Initiative em colaboração com o Canadian Biotechnology Advisory Committee, Canadian Institutes of Health Research, Genome Canada, Health Canada, and Industry Canada, intitulado Genômica, Saúde e Sociedade: questões emergentes para a política pública (Knoppers \& Scriver, 2004), que relata um simpósio internacional sobre o tema, encontro ocorrido em Toronto em 2002 e alguns desenvolvimentos posteriores. Nele, abordam-se aspectos econômicos e empresariais, a medicina genética e problemas de privacidade, propriedade e patenteamento, implicações para o mundo em desenvolvimento e relações com os governos.

Apesar da indiscutivel relevância de todos os itens, para efeitos de nossa discussão, interessa-nos enfocar as apregoadas 'implicações para o mundo em desenvolvimento' e também o subtexto a respeito das responsabilidades pessoais envolvidas na epidemiologia genômica.

\footnotetext{
${ }^{26}$ Já assinalamos o problema da falta de referentes na ciência positivista sobre as conexões de verificação entre os processos in vivo, in vitro e in silico. Este déficit enorme na epistemologia positivista é possivelmente responsável tanto pelas grandes discordâncias e faltas de reprodutibilidade de muitos experimentos, como pela falta de resultados realmente úteis até 0 momento. 0 perigo de uma verdadeira mudança revolucionária, no sentido kuhniano de mudança de paradigmas, começará quando a genômica finalmente invente algo que sirva para saúde humana em termos coletivos. Em meados do século XX, o sonho da era antibiótica de que toda a doença era produzida por um microorganismo e que cada microorganismo teria seu tratamento antibiótico foi possível graças ao espetacular efeito da penicilina sobre doenças freqüentes e graves, como a pneumonia.
} 
A dura afirmação de que

a hipótese dos determinantes genéticos da saúde possa ter um significativo impacto na saúde pública e no sistema de atenção à saúde em geral se aplica somente a países desenvolvidos com infraestruturas sociais requeridas para estudos de correlação genótipo-ambiente (Laberge, 2004: 20)

se mostra difícil de refutar, mas por razões diferentes das que o autor alega: as ações neste sentido não podem ser tomadas como resposta a demandas por serviços baseadas em 'amostras enviesadas' para serviços que se dirigem a toda a população. Ora, esta afirmação parece supor a inexistência nos países em questão ou de recursos/competência para produzir investigações (com ou sem vieses) ou se existem tais estudos, não há garantias suficientes para garantir a qualidade metodológica que sustente a fidedignidade dos achados.

Tal comentário deixa entrever bem mais a contumaz postura de conhecimento parcial dos contextos de investigação dos países ditos em desenvolvimento do que seria desejável para um juízo desta ordem e alcance - na melhor das hipóteses. Um modo pouco original e reiterativo de culpabilização da vítima.

A nosso ver, apesar de este não ser o foco desta discussão e de a argumentação correr o risco de soar como clichê, a eventual precariedade de recursos financeiros e de pessoal de pesquisa em países como os da América Latina merece uma análise menos apressada. Devemse considerar: dimensões históricas relativas às formas como a pesquisa em geral e a da saúde em particular foi estrangulada por governos ditatoriais. E, com a queda destes, limitadas por condições insustentáveis de pagamento de dívidas externas, ambas decorrências, inclusive, de ditames estabelecidos por nações encaradas como potências do mundo desenvolvido. Mesmo assim, existem muitos esforços nestes contextos e há sinais locais de excelência acadêmica, ainda que em escala reduzida, que levam a relativizar este tipo de afirmação que se torna incomodamente conservadora, mas que é emblemática na sua formulação categórica ao veicular uma meia-verdade que parece possuir bem mais a função implícita de atuar como profecia auto-realizável.

Essas críticas, que podem parecer exacerbadas, se justificam ao se conhecerem outros enunciados discutiveis nos quais Laberge assinala que a nova genômica em saúde no longo prazo promete um melhor entendimento de fenômenos adaptativos entre indivíduos e outros genomas que nos afetam como os de micróbios, entre indivíduos e ambientes tóxicos ou medicações e até "fenômenos sociológicos como a pobreza" (Knoppers \& Scriver, 2004: 21).

Aqui é possível perceber como subtexto um mal disfarçado ranço preconceituoso no qual a pobreza se definiria por sua 'etiologia genética', justificando, no limite, ações eugênicas. Ainda, no parágrafo final, o inexorável apelo culpabilizante à responsabilidade pessoal em relação à saúde que tornaria a saúde pública o resultado da decisão individual de cidadãos, a partir do conhecimento da distribuição dos fatores individuais de saúde que a genômica populacional traria. 
Esta desagradável impressão é contornada por outro texto do relatório que aborda a brecha norte/sul relativa à 'saúde genômica' e propõe encaminhamentos para sua superação (Hofman, Anand \& Keusch, 2004). Os autores afirmam que a defasagem em capacidade de pesquisa entre países do Norte e do Sul se amplia mais rapidamente e é mais evidente nas ciências genéticas. Isto ocorreria em função dos altos custos da investigação neste setor, sobretudo por parte de investimentos privados que esperam retornos correspondentes. Além disso, ponderam que o estado corrente da expertise em biotecnologia varia amplamente entre países e continentes.

Mesmo assim, há que se conceber e colocar em ação mecanismos capazes de enfrentar necessidades infra-estruturais, necessidades de pesquisa, barreiras financeiras, barreiras éticas, legais e sociais. Para estas regiões, as prioridades em pesquisa genômica recairiam em cinco niveis: treinamento e tecnologia para integrar diagnósticos já disponíveis com técnicas de DNA de custo relativamente baixo; pesquisa em vacinas e terapêutica para tuberculose e HIV/Aids; terapêutica, vacinas e diagnósticos em doenças negligenciadas por pesquisadores do Norte por não haver mercado no mundo desenvolvida envolvendo, por exemplo, lepra, dengue, malária, doenças do sono; parcerias para estudos voltados à terapêutica para doenças crônicas, como diabetes e câncer, que também são prioridades no Norte; farmacogenômica, ou seja, o exame das implicações da variabilidade genômica em respostas individuais às drogas (como veremos mais adiante, em outro informe da OMS sobre a genômica e a saúde do mundo, se faz um diagnóstico equivalente).

Uma variação a esta perspectiva de 'responsabilidade genética' pode se apresentar sob o manto mais diáfano da 'solidariedade genética'. No informe "Ponderando interesses no uso de dados genéticos pessoais", de 2002, da Comissão de Genética Humana - um consetho independente do Departamento de Saúde do governo inglês que se dedica a abordar aspectos sociais e éticos em genética humana -, há as seguintes referências:

(o) conhecimento genético pode trazer uma relação especial uns com os outros. Vivemos nossas vidas como membros de grandes e pequenas comunidades, e temos certos deveres [grifo nosso] a outros membros destas comunidades. Tais deveres podem incluir não causar dano aos outros e e fazer coisas para ajudá-los. Compartilhar informação genética pode dar oportunidades a ajudar outras pessoas e outras pessoas nos ajudarem e temos um interesse comum nos benefícios que a pesquisa genética possa trazer. Portanto, propusemos o conceito de solidariedade genética e altruísmo [grifo dos autores]. Isto sustenta a idéia de, por exemplo, ainda que ninguém deva se sentir forçado em participar em uma pesquisa genética, quando tomam esta decisão, as pessoas devem estar conscientes que ao participar, podem ajudar aqueles que sofrem de doenças. (Human Genetics Commission, 2002: 6-7) 
Petersen (2003) assinala que esta tendência não é nem uniforme nem absoluta. Existem até movimentos de descrença e resistência por parte de grupos de mulheres, minorias étnicas e portadores de déficits físicos, particularmente no que se refere à chamada 'reprogenética' tecnologias genéticas dirigidas à reprodução. Ainda, para o sociólogo australiano, tal conceito refletiria um deslocamento do ideal comunitário enfeixado pela idéia de 'solidariedade social', que se baseava na coesão do tecido social com a predominância de interesses compartilhados.

Além disto, na 'solidariedade genética', tenta-se replicar uma ordem de sentimentos e laços sociais mais densos para contextos em que predominam fluidez e transitoriedade, com alto grau de incompatibilidade com tais padrões de configuração comunitária. A designação de 'solidariedade' aqui dá a impressão de lutar para não assumir seu destino eufemístico, como no caso da expressão 'comunidade solidária', onde, pelo menos, a idéia incômoda de 'obrigação' pareça se atenuar. Isto aparece na construção redundante, mas, diante das circunstâncias, necessária, com que se organizaram determinadas políticas públicas e planos governamentais de assistência social no Brasil a partir do final dos anos 90, denominada justamente Comunidade Solidária - algo que seria um pleonasmo em outras situações. $\mathrm{Ou}$, talvez, com menos boa vontade, pode-se dizer que a noção de responsabilidade estaria vigente sob uma forma camuflada. Mas seus imperativos morais de caráter biopolítico permanecem atuando em termos de mensagens ambíguas - apesar de não haver 'coerção', há o dever de ser solidário e de fazer o bem comum.

A idéia de estimular a criação de uma 'genômica solidária' está implícita em um informe especificamente dirigido ao desenvolvimento de colaboração em vários níveis em termos genômicos entre centros tecnologicamente avançados e países do terceiro mundo, elaborado pela Organização Mundial da Saúde (WHO, 2002). O título do informe é "Genômica e a saúde do mundo" dedicado ao 'potencial da genômica' para a saúde nos 'países em desenvolvimento'.

A diretora geral da OMS à época (2002), a norueguesa Gro Harlem Brundtland, assume, na introdução do documento, aspectos óbvios. Mesmo assim, eles precisaram ser reiteradamente explicitados, para que não pairassem dúvidas quanto à sua premência: "é realidade que a maior parte da pesquisa genômica e biotecnológica é, na atualidade, realizada no mundo industrializado e está primordialmente dirigida ao mercado. A genômica deve ser também aplicada aos problemas de saúde do mundo em desenvolvimento" (Brundtland, 2002: 13).

No informe, apresentam-se tópicos relativos ao que é encarado como factível no presente (a exemplo do documento canadense Genômica, Saúde e Sociedade: questões emergentes para a política pública, anteriormente discutido): abordagens de hemoglobinopatias, estudos de resistência genética em doenças transmissíveis, diagnóstico via DNA em doenças transmissiveis, organismos resistentes a drogas, faramacogenômica, doenças não-transmissíveis.

Além disto, são abordadas, entre outras dimensões, o desenvolvimento e a disponibilização de serviços de genética clínica e tecnologia de DNA, a genômica para o controle de doenças 
transmissiveis, o estabelecimento de parcerias internacionais na academia, colaborações regionais e desenvolvimento de tecnologias de comunicação e de bioinformática. Há também capítulos sobre educação e políticas públicas, aspectos éticos relativos à pesquisa, screening e testagens genéticas com ênfase aos países em desenvolvimento (WHO, 2002).

Ainda na introdução, a diretora geral faz um comentário aparentemente inócuo, ao declarar que é "crucial que nós busquemos ativamente meios de envolver cientistas de países em desenvolvimento para biotecnologia inovadora" (Brundtland, 2002: 13) (e esta frase não está retirada do contexto, pois segue imediatamente à citação anterior). Ora, quais cientistas destes países teriam deixado de participar de projetos biotecnológicos inovadores por necessitarem de meios de 'envolvimento' ativo para essa proposta apoiados pela OMS ou de instâncias equivalentes? Salvo profundo e injusto engano e/ou leitura apressada nesta análise, talvez caiba levantar uma pequena dúvida quanto às possibilidades de existir uma conotação levemente culpabilizante nas entrelinhas deste texto quanto a uma suposta falta de disponibilidade aparentemente localizada nos pesquisadores de se abrirem a óbvias questões de desenvolvimento biotecnológico.

Inegavelmente, em síntese, o documento constitui-se em uma promissora carta de intenções, aos moldes de muitos outros produzidos pela OMS. Independentemente disto, propicia um oportuno e detalhado mapeamento do campo genômico e de suas possibilidades de aproveitamento para além das fronteiras do mundo das democracias liberais avançadas. Pois, como se pode verificar em dois trechos do informe - em relação específica ao acesso a técnicas e tecnologias informáticas e computacionais (p. 104) e no comentário final com as mensagens-chave (p. 198) -, é essencial que o campo da genômica seja acessível de modo que o "mundo em desenvolvimento não seja deixado para trás".

O memorável e saudoso sanitarista Carlos Gentile de Mello costumava dizer, com ceticismo, mas de modo curiosamente otimista, no final dos anos 70, diante de planos de reforma da previdência social brasileira e das recorrentes dificuldades de implementação nestes tempos: 'Melhor do que isto, só se for verdade...' Nosso desejo é de que este informe não se constitua em uma versão do terceiro milênio de planos que infelizmente ficaram no papel, ou agora, em versão tecnologicamente sofisticada, que talvez fiquem nos discos rígidos dos computadores ou nas memórias externas - uma espécie de saúde genômica para todos depois do ano 2000, sem que se evolua, nesta direção, de modo concretamente satisfatório (a exemplo do que ocorreu com o lema da OMS nos anos 1980 e 1990 "Saúde para todos no ano 2000"). 



\section{Os Riscos da Responsabilização Individual na Genomização Epidemiológica}

Com a epidemiologia genômica, vivemos um momento em que considerar genes como causas suficientes de doenças ('genetização') parece estar passando por uma significativa inflexão. Parece que, para além da ênfase que nos levava a pensar em genes responsáveis por determinadas doenças, adentramos em uma nova fase, ensejada pela epidemiologia do genoma humano, que também inclui um formato extensivo no qual se consideram os genes como causas necessárias de doenças ('genomização epidemiológica'). Se as doenças sempre apresentam um componente genético, mesmo que débil, tentar abordá-lo e neutralizá-lo é benéfico em termos de saúde pública. Por esta razão, a epidemiologia genômica estuda grandes contingentes populacionais para, com isto, os resultados destas investigações possuírem robustez para detectar as sutis variações envolvidas.

Ainda assim, infelizmente, várias das críticas feitas à genetização (Willis, 2000) continuam valendo para a genomização, sobretudo se imaginarmos que agressivas companhias de biotecnologia, como a Genzyme, desenvolvem testes genéticos para doenças crônicas prevalentes (doenças coronarianas, hipertensão arterial, diabetes, acidentes vasculares cerebrais etc.). Ainda que suas ações sejam débeis ou dependentes do 'ambiente', por isto mesmo, sabendo-se de sua virtual existência, mais se justificariam as medidas que visam a atuar nos aspectos extragenéticos. E, daí, basta um passo para os discursos da responsabilização pessoal e culpabilização virtual das 'vítimas' do risco.

Sim, porque não é absurdo imaginar o potencial de tais testagens no sentido de atualizar, no âmbito da promoção da saúde genômica, a ficção criada por Philip K. Dick em seu "The minority report", e criar um novo estatuto que representa bem a virtualidade de nossa época: a responsabilização pela probabilidade de algo que ainda não ocorreu, mas pode acontecer em função de certos indícios. Ou, em termos mais usuais e enfáticos, diante de 'evidências de risco genético ${ }^{27}$ - uma construção híbrida própria da virtualidade, ao preten-

${ }^{27} \mathrm{~A}$ noção de risco genético também merece uma reflexão sobre sua sensibilidade epistemológica. Prevalece a idéia de que o risco genético é mais determinante que o não-genético, como, por exemplo, aquele derivado do hábito de fumar cigarros. Isto está correto nas enfermidades de transmissão mendeliana pura, 
der-se aumentar a previsibilidade em nossas relações com o destino, estas participam do aumento da sensação de incerteza corrente. Está longe de ser simples a gestão de múltiplas escolhas em um contexto abstrato em que se mesclam elementos manifestos e latentes com vistas a evitar desfechos indesejáveis.

Ademais, resultados positivos de testagens dirigidas a testar a dimensão genética de doenças crônico-degenerativas de um indivíduo podem também afetar outros membros da família. ${ }^{28}$ Tanto no sentido de virem a conhecer aquilo que não gostariam de saber, como de não lhes ser oferecida ou viabilizada a possibilidade de acesso a tal informação, uma vez disponível para outro familiar.

A genomização veiculada pelas testagens genéticas pode levar a uma dupla responsabilização, tanto no sentido de um superdimensionado peso de fatores genéticos sobre aspectos sociais e ambientais (para além da exposição a ambientes e contextos de trabalho patogênicos), como em direção ao reducionismo genético e às explicações sociobiológicas do comportamento humano, aos moldes dos 'genes perversos', já mencionados. Neste último caso, isto combina com o arcabouço neoconservador vigente que entende o adoecimento sob o ponto de vista eminentemente individualista e biologicista.

Tal perspectiva, como vários autores já citados apontam (Lupton, 1995; Robertson, 2001; Willis, 2000), tem afinidades com a primazia globalizante de criação de mercados, o otimismo biotecnológico como componente fundamental para as práticas de saúde, com o movimento de diminuição do tamanho do estado e com o o aumento do controle social tanto por meio de ações 'panópticas' de biovigilância (como na obrigatoriedade de testagens genéticas para a obtenção de emprego) quanto por meio de ações 'sinópticas' (como no caso da estimulação individualista de sentimentos de culpa por não se procurar saber níveis de risco genômico a várias enfermidades, seja para si, como para seus familiares).

Esse panorama se ajusta bem com as preocupações em termos da promoção da saúde com o estilo de vida saudável. Se, por exemplo, um indivíduo tem níveis normais de colesterol,

como, por exemplo, a Coréia de Huntington. Mas os problemas de utilização do risco na medicina e na saúde pública provêm não da condição genética - sim ou não de uma determinada variável preditora -, mas da aplicação de uma medida populacional a uma pessoa. Quando falamos de risco genético, temos de considerar que serão tratadas muitas pessoas sadias que nunca desenvolverão a doença para prevenir-se um caso. 0 problema com a popularização da genômica e com a medicina de futuros é que o nivel de angústia que se gera na população ao saber-se o risco - um caso de iatrogenia virtual - se atenua com 0 tratamento. 0 caso das mastectomias preventivas para evitar o câncer de mama exemplificam bem este problema.

${ }^{28}$ Uma questão que merece ser analisada aqui é a chamada 'discordância parental'. Enquanto que todos somos filhos de nossas mães, nem todos somos filhos de nossos pais. As técnicas de screening genético podem ter como consequiência adversa o reconhecimento de situações equivocadas quanto à verdadeira paternidade biológica que não foram requeridas e, também, a realização de tratamentos desnecessários em pessoas que não são biologicamente filhas de seus pais. A ocorrência deste fenômeno é estimada como 1 em cada 25 pessoas (Bellis et al., 2004). 
mas tem outras predisposições genéticas, ainda que pequenas, a doenças coronarianas, também se colocam os apelos racionalizantes à responsabilidade individual no sentido da tomada de atitudes saudáveis através do consumo ativo de bens e serviços a partir de escolhas supostamente bem informadas. Em outras palavras, instituem-se assim 'prerrogativas' do consumidor, para exercer seu 'direito' de ser informado para decidir e dispor de 'liberdade' de escolher tecnologias e conhecimentos com vistas a proteger sua saúde e a dos seus e, também, a ampliar o bem-estar.

A opção é balizada por sua capacidade de acesso ao consumo e pelo contexto socioeconômico mais amplo. $\mathrm{O}$ que fazer com enormes grupos populacionais que não podem atuar efetivamente como agentes de consumo? Na melhor das hipóteses, poderão receber ajuda de campanhas solidárias. Se isto é cabível, em certa medida, para necessidades essenciais de sobrevivência, como será o acesso a eventualmente sofisticados e onerosos testes genéticos? Possíveis respostas ainda não parecem estimular expectativas alvissareiras.

Essas dimensões não costumam receber ênfase nos discursos dominantes da 'nova' genética, na qual o 'nova' parece funcionar como indicativo de fronteira entre a 'antiquada' $\mathrm{e}$ repressora genética eugenista da proposta atual que cada vez mais assume a denominação 'genômica' aparentemente progressista e liberadora que a desvincularia de modo cabal desta última. Enquanto a 'velha' eugenia operava repressivamente via autoridade estatal, a genômica moderna atua principalmente pelos mecanismos de mercado e usa a linguagem de 'empowerment' individual e da liberdade de escolha do consumidor.

Podemos associar a última grande guerra e suas 'razões' étnicas ao mesmo imaginário mítico discriminador e purificador subjacente à real capacidade da nova genética molecular identificar etnias e seu (suposto) potencial eugenista. Temos, portanto, nós - profissionais da saúde, tarefas essenciais na educação sanitária: detectar, denunciar e desmontar os dispositivos discursivos que possam sustentar idéias incompativeis com qualquer posição não só moral, mas também política.

\section{$\diamond \diamond \diamond$}

Agora, é preciso traçar uma breve 'genealogia' recente das idéias de responsabilidade genética. Pode-se cogitar suas supostas origens a partir dos evidentes avanços tecnocientíficos da genética iniciados nos anos 70, como o screening para determinadas doenças e o florescimento de tecnologias de reprodução assistida.

Um emblema do espírito desta época aparece com a publicação do compêndio editado por Lipkin e Rowley (1974) que ostenta sinopticamente tais premissas (liberdade de decidir e direito de escolha diante da preocupação e da responsabilidade com a linhagem gênica da prole de cada casal, a partir dos conhecimentos e da capacidade de intervenção genética): Genetic Responsibility: on choosing our children genes. Podem-se incluir também a resposta biopolítica conservadora de chamamento à razão e à responsabilidade individual para enfrentar 
a suposta irresponsabilidade dos hábitos e costumes transgressores que vicejaram nos anos 60 (Heller \& Fehér, 1995). Os comportamentos transbordantes do Flower Power deveriam dar lugar à conduta comedida do Responsibility Reasoning que começava a prosperar.

Simultaneamente, começavam os programas e as mudanças econômicas de ajuste neoliberal que também individualizavam e privatizavam os riscos sociais. Isto se dava em função da crise do Estado de Bem-Estar Social que levou ao encolhimento do Estado e ao crescimento da noção de dever em relação à auto-regulação que geraram a ênfase nos discursos de autocuidado (Lemke, 2005b).

Cabe ainda salientar que com o avanço das técnicas de manipulação genética, o campo dos conhecimentos em saúde pública passou a ter de lidar com o surgimento de duas concepções genéticas discutiveis que se complementam: o 'determinismo' (genes são causas necessárias de doença) e o 'reducionismo' (genes são causas suficientes de doença), nas quais se exalta em demasia o poder causal dos genes - para além das influências do meio ambiente e do contexto socioeconômico. Ainda que, na genomização epidemiológica, pareça haver uma atenuação do determinismo, o reducionismo exerce plenamente sua influência. Nestas circunstâncias, o foco principal das intervenções em saúde coletiva estaria mais voltado para a abordagem genômica de 'indivíduos' e suas 'famílias' em detrimento de seu objeto consagrado - populações, seus ambientes e modos de viver. A ênfase dos esforços (e recursos) sanitários afastar-se-ia, em tese, da luta contra as desigualdades em termos socioeconômicos com vistas a reduzir o adoecimento humano. A 'falácia individualista' (Hallyday et al., 2004) é uma forma apropriada de denominar tanto esta circunstância como a preocupação pela regulação voltada à ênfase exacerbada na adoção de comportamentos saudáveis.

A expressão 'responsabilidade genética' pode ser compreendida de duas formas que nem sempre estão claramente explicitadas, mas que tendem a se superpor: referente à dimensão biocientífica determinista, relativa à esfera gênica de suposta influência causal e relativa a valores morais envolvendo dever e culpabilidade. Aqui, se destaca a expectativa dirigida ao indivíduo, que deve administrar prudentemente seus riscos através de decisões supostamente bem informadas quanto ao estilo de vida baseado em dados provenientes de exames genéticos (Lemke, 2005b).

Sem dúvida, as idéias eugênicas fazem parte deste cenário. O terreno da discussão eugênica é abundante, mas, infelizmente, não faz parte de nossos propósitos entrar em seus meandros e sutilezas, ainda que esta tarefa se mostre indiscutivelmente importante. Ademais, qualquer discussão sobre tais práticas e as tentativas de estabelecer limites entre o pensamento eugênico coercitivo de 'purificação' racial excludente em relação às novas perspectivas genômicas, apregoadamente dirigidas à saúde e ao bem-estar público, merecem ser muito bem especificadas diante da grande delicadeza do tema em função dos funestos eventos do passado recente.

Eugenia pode ser vista como sendo o conjunto de teorias e práticas voltadas para a melhoria da qualidade da espécie humana por meio da manipulação de aspectos biológicos, 
tanto no sentido de estimular dimensões desejáveis como de evitar traços indesejáveis (Kevles, 1992). Como assinala Lemke (2005b), há nítidas dificuldades para se traçar esta fronteira. Tais circunstâncias indicam a necessidade de estudos sócio-históricos sobre as práticas e políticas eugênicas contemporâneas de forma a serem distinguidas da ideologia eugênica autoritária e cruel do passado. Esta se localiza no primeiro período eugênico, entre 1930 e 1940, espalhando-se pela Europa, Estados Unidos e outras partes do mundo, inclusive o Brasil. Consistiam em práticas de controle com vistas à 'melhoria da espécie', incluindo segregação, esterilização e, evidentemente, eliminação, no notório caso da Alemanha hitlerista.

No decorrer da década de 1950 até a primeira metade dos anos 70, surgiu e se desenvolveu o modelo genético de prevenção à saúde bem como o aconselhamento não-diretivo como uma tentativa do campo de livrar-se da imagem da eugenia exterminadora nazifascista. No final dos anos 50, a eugenia reformista foi renomeada como 'genética humana', e a 'higiene genética' recebe a denominação 'aconselhamento genético' (Kerr \& CunninghamBurley, 2000). Sob esta formulação, temos o aparecimento dos ideais de ação responsável a partir do conhecimento do risco genético para tomar as melhores decisões cabíveis ao planejamento das vidas de cada um. Ao mesmo tempo, coexistiam os propósitos de minimizar as ansiedades e receios em função das incertezas trazidas pela apresentação dos riscos de doenças genéticas.

De meados da década de 1970 até o início do ano 2000, começa a fase do aconselhamento com base na comunicação dos riscos genéticos para várias afecções com o propósito de maximizar a longevidade e ampliar a qualidade de vida, além das doenças genéticas para as quais foram desenvolvidas novas técnicas pré-natais. Nestas circunstâncias, aumenta o apelo ao indivíduo autônomo que deve fazer escolhas informadas e responsáveis em um processo constante de auto-atualização. Aos poucos, nos anos 90, as medidas de prevenção passam a incluir ações de mudanças no estilo de vida (Novas \& Rose, 2000). Em suma, prevalece uma noção liberal-iluminista de busca de conhecimento como consumidores exigentes que devem, assim, saber selecionar os produtos mais bem indicados para seus casos (e bolsos) no mercado.

Pode-se encarar a 'nova eugenia' ou 'eugenomia' como aquela que se funda no discurso do risco genético. Antes que os leitores se mostrem apreensivos com academicismos inoportunos, cabe esclarecer que a expressão 'eugenomia' é, tão-somente, uma tentativa de neologismo que sirva para sintetizar a fusão da idéia de uma neo-eugenia, a partir dos conhecimentos do genoma com a forte possibilidade desta noção se instituir sob a égide de diretrizes sociais que alcançam estatuto de lei moral - nomos.

Se os resultados de testagens gênicas configuram-se em termos de construções probabilísticas - de risco genético, estes elementos passam a engendrar novas bases para práticas eugênicas que não mais se dirigem a determinados indivíduos ou grupos bem 
demarcados (judeus, insanos, criminosos, entre outros), mas potencialmente a todos. Vejase, por exemplo, o fato de que toda a gravidez estar passivel de ser configurada em termos de níveis altos ou baixos de risco (Lemke, 2005b).

Os discursos de responsabilidade genética são passiveis de serem encarados teoricamente sob a perspectiva foucaultiana como um elemento estratégico pertencente à governamentalidade ou governância genética (Lemke, 2005a). Como tais conhecimentos e tecnologias são empregados para a regulação de indivíduos e grupos humanos e como correspondentes práticas médico-sanitárias e seus dispositivos diagnósticos e epidemiológicos atuam como tecnologias políticas e morais. Mas é possivel considerar que a posição de Foucault em relação à genética seja mais de resistência que de antagonismo e de especificação mais do que indicação de alguma forma maniqueísta e prescritiva de moralidade. Não cabe advogar irresponsavelmente contra os enormes benefícios potenciais do conhecimento genômico. Nossa tarefa é a de tentar estabelecer que dimensões dos avanços propiciados pela genômica, sob o manto aparente da 'imparcialidade' cientifica sustentam e ampliam desigualdades sociais e subjugam a existência humana tornando-a refém biopolítico de informações genéticas (Coors, 2003).

Se prestarmos atenção aos argumentos do filósofo Philip Kitcher (1997) sobre eugenia, podemos perceber alguns pontos passiveis de discussão, pois envolvem aspectos relacionados à responsabilidade genética. Para ele, com o desenvolvimento do conhecimento genético, a eugenia será um componente inexorável de nossa vida social, tanto do ponto de vista empírico como normativo. Empírico, porque haverá fortes razões que motivarão muitos a buscarem dotar seus filhos com aperfeiçoamentos genéticos, se dispuserem de acesso a isto. Normativo, porque seria moralmente irresponsável não usufruir das vantagens de tais tecnologias, se se dispõe de tais capacidades e se pode arcar com os custos para prevenir o sofrimento de crianças ainda não nascidas.

Portanto, para Kitcher, teríamos entrado na era da responsabilidade genética. ${ }^{29}$ Esta situação reflete o que ele denomina 'eugenia utópica' que se ancoraria no valor essencial da liberdade reprodutiva que deve modelar as práticas eugênicas. Isto para diferenciar da 'eugenia laissez-faire' que, sobretudo, apresenta fortes distorções em termos de acesso aos menos bem

29 Já discutimos alguns aspectos relativos à noção de responsabilidade, mas, talvez valha a pena deter-se um pouco mais no 'tempo' como variável. A dotação genética dos indivíduos é o resultado da corporização histórica de forças sociais. Por exemplo, já foi mencionada a brecha existente entre o Norte e o Sul em termos de tecnologia genética. Muito provavelmente, no futuro, a carga de enfermidades geneticamente determinadas venha a ser maior nos países do Sul. Dentro de quatro ou cinco gerações, um determinado indivíduo deverá ser responsável pela corporização em seu genoma das atuais desigualdades Norte-Sul? Terá este hipotético indivíduo a mesma responsabilidade genética que algum contemporâneo seu, com o mesmo padrão genético e que vive, assim como a seus ancestrais viveram, no Norte? Os promotores da responsabilidade genética assumem um discurso a-histórico em relação ao genoma. 
aquinhoados em termos de informação e de recursos econômicos. Então, ao mesmo tempo que deve haver liberdade reprodutiva para todos em uma sociedade, uma eugenia responsável deve gerar limites em tal liberdade (Fleck, 1999).

As práticas eugênicas responsáveis seriam aquelas que mesclam a liberdade reprodutiva individual com a educação e discussão pública sobre procriação responsável, desde que isto não seja a expressão de preferências como cor de olhos, tipo de pele, de cabelo, de tendência à obesidade ou preferências sexuais. Mas, Kitcher também apóia a noção de que os pais têm o direito de decidir se terão seus filhos após a devida informação (grifo nosso), especialmente em relação a graves doenças genéticas - como aquelas descritas pela empresa Genzyme, entre outras - que irão afetar fortemente a qualidade de vida da criança atingida e provocar profundas dificuldades para a família. Nestes contextos, a questão é estabelecer os limites em relação ao moralmente admissivel, as escolhas eugênicas responsáveis em relação às formas de discriminação genética.

A responsabilidade genética também aparece nas concepções de Novas e Rose (2000) sobre as mudanças da subjetividade na contemporaneidade. Para estes autores, o 'indivíduo sob risco genético' seria o elemento-chave no aparecimento da nova genética molecular. Mas a possibilidade de 're-catalogar' patologias em um eixo genético não geraria fatalismo, e sim 'obrigações' de agir preventivamente, ou seja, 'responsabilidade genética'. As linguagens e técnicas genéticas configurariam uma individualidade somática a partir destes elementos biológicos de modo a participar da geração de uma 'pessoalidade responsável empreendedora' (enterprising responsible personhood).

Deste ponto de vista, o indivíduo-paciente deve adquirir habilidades (skills) ser um 'aliado do médico, um protoprofissional - e assumir sua parte de responsabilidade para melhorar' (...), "livre, porém, responsável, empreendedor, prudente, encorajado para uma conduta na vida de modo calculado através de atos de escolha com vistas ao futuro e a um progressivo bem-estar para si e para sua família” (Novas \& Rose, 2000: 489-490). Em outras palavras, ao se tornar parte de uma 'rede genética', o indivíduo sob risco genético - que talvez, no futuro, poderá se transformar em 'indivíduo geneticamente sob risco' -, em tese, teria condições de reavaliar suas relações familiares e íntimas em termos de risco e hereditariedade, de modo, inclusive, a conformar seu estilo de vida nestes termos.

A este respeito há aspectos passíveis de discussão. Em primeiro lugar, há que se considerar que a categorização de risco genético pode seguir uma racionalidade contextual relativa aos modos como se organizam os serviços públicos de genética clínica, como é o caso de países como da Inglaterra. Nestes contextos assistenciais, são inevitáveis o racionamento de recursos assistenciais e a conseqüente seleção dos que serão atendidos ou não por médicos, conforme determinados critérios de risco/benefício. Este aspecto reflete o fato de que pesquisadores científicos e profissionais clínicos precisam operar sobre conjuntos de pessoas, objetos e interesses para pôr em funcionamento suas tecnologias. Tais conjugações não 
consistem em detalhes colaterais do fazer científico, mas pertencem ao seu núcleo, ainda que sejam encarados nos âmbitos de atenção clínica como fatores extra ou para-científicos, ao serem contingenciados por contextos socioculturais, econômicos e políticos (Prior, 2001).

Por exemplo, um estudo qualitativo realizado na Inglaterra realizou entrevistas com 58 usuários de uma clínica genética que receberam estimativas de risco genético. Os pesquisadores analisaram-nas juntamente com dados derivados de consultas clínicas. O objetivo era avaliar as formas com que estes pacientes atribuíam significados às estimativas de risco genético e como integravam tais informações em suas vidas particulares. Tais indivíduos sob risco tendiam a ver-se em uma posição limite entre saudáveis e doentes e também buscavam recursos em sistemas de vigilância à saúde para acompanharem suas condições de saúde (Scott et al., 2005).

Nestes contextos assistenciais, os que recebem a categorização 'alto-risco' são encaminhados a atendimentos com contato pessoal com clínicos e os demais (risco 'baixo' ou 'moderado'). Os resultados mostraram que pacientes considerados como de baixo risco para herdar mutações relacionadas ao câncer procuraram ser recategorizados como de risco moderado ou elevado. Uma hipótese levantada pelos investigadores para estes aspectos aparentemente paradoxais seria algo mais do que a possível ansiedade pelo estado 'indefinido' de baixo risco, em termos de espera para a adoção de medidas de saúde definidas. Mas, sim, o foco dirigido à possibilidade de acesso a benefícios de assistência à saúde por estarem associados à definição da situação de risco do que com a suposta probabilidade futura de eventos relacionados ao câncer (Scott et al., 2005).

Koch e Svendsen (2005) propõem que, no contexto do aconselhamento genético, as 'soluções' disponíveis definidas pelo serviço proporcionam o arcabouço para que certos problemas sejam enunciados e manipulados pelos próprios serviços de assistência genética e não o fato de que a existência dos problemas genéticos das pessoas é o que as levam a procurar por soluções a demandar do serviços (Koch \& Svendsen, 2005). Através de uma pesquisa qualitativa de uma clínica de aconselhamento sobre o câncer, discute-se como as novas estratégias preventivas se tornam o ponto de referência por meio do qual os fatores de risco são demarcados e as demandas assistenciais, definidas.

Essa racionalidade pode ser entendida sob a perspectiva da 'governância genética', uma vez que há um imperativo de escolher-se a prevenção à doença de modo a subverter os preceitos de não-influência, autonomia e consentimento informado que deveriam caracterizar o aconselhamento genético. No decorrer da transmissão de conteúdos e de conhecimentos sobre riscos genéticos entre especialistas e os usuários dos serviços, há estímulos que sustentam a noção de indivíduo autônomo que, através de sua capacidade de escolha, aceita assumir responsabilidade pessoal por si próprio e por seus entes queridos.

Para Koch e Svendsen (2005), esta prática de engenharia de saúde participa da manutenção das propostas hegemônicas de produção de conhecimento com vistas à prevenção de doenças em termos da grande relevância de ações responsáveis. Neste processo, o conheci- 
mento da condição de riscos genéticos de cada um se torna necessário e obrigatório para a prevenção de doença, constituindo-se como uma tecnologia social que produz biossubjetividades ao estabelecer modos de relacionar-se consigo mesmo, com a família e a sociedade.

Outro aspecto discutivel em relação à responsabilidade genética proposta por Novas e Rose refere-se aos efeitos do surgimento de 'pessoas pré-sintomáticas' como resultado das testagens para doenças genéticas, proposta por Konrad (2003). Em seu estudo antropológico, levanta questões sobre o significados culturais relativos à identidade biológica (ou somática) e o estatuto dos conhecimentos de saúde per se. Em relação às 'profecias revelatórias' das novas tecnologias genéticas preditivas em relação ao mal de Huntington, a autora afirma que, nestas situações, pessoas leigas se tornam 'prognosticadores morais'. Indivíduos com casos de Huntington na família passariam a considerar moralmente doentes familiares que ainda não apresentam sinais físicos da doença.

Será que cabe cogitar que, no caso de doenças não-genéticas, poderão surgir os diagnósticos morais dos 'indivíduos sob risco', por exemplo, de doenças coronarianas, ao apresentarem alta pontuação nos escores de risco específicos (e não apenas genéticos) para esta doença? Como se houvesse aparecido uma nova condição de 'patologia' pré-patológica, como um estado intermediário que não é nem de doença, mas tampouco é de saúde. Algo como um estado de purgatório no qual o possível conhecimento sobre os próprios riscos acaba por criar o paciente preventivo, consumidor de medidas de proteção (Konrad, 2003).

Além disto, a noção de 'responsabilidade genética' exposta por Novas e Rose anteriormente descreve as características das proposições biopolíticas neoconservadoras para a constituição de uma nova normalidade com fortes repercussões na esfera das tecnologias de si mesmo, com evidentes ancoramentos morais. Neste ponto, devem ficar explícitas as afinidades entre a genômica e projetos de privatização da economia globalizada, ligados, sobretudo, à redução da carga fiscal dos programas sociais que se tornaram dispendiosos. Em resumo, a privatização implica também a re-estruturação de instituições econômicas e sociais de modo a promover nos países centrais os interesses do setor privado e nos demais países, sobretudo, o retorno de investimentos não-produtivos.

Como ilustração da afinidade da responsabilidade genética com a privatização da economia globalizada, há um recente filme de ficção científica distópica, A Ilha (The Island, 2005), dirigido pelo especialista em filmes estrepitosos de ação em ritmo de videoclipe, Michael Bay, com roteiro de Caspian Tredwell-Owen. É possivel identificar, no enredo, vários pontos em comum com outras obras de ficção científica, incluindo o clássico Blade Runner.

Em síntese, em meados do século XXI, Lincoln Six-Echo é um indivíduo que reside, com outras pessoas, em uma instalação panóptica, cuidadosamente controlada. O grande sonho de todos é o de serem escolhidos para irem para 'a ilha', um lugar curiosamente 'paradisíaco', pois seria o último local não contaminado do planeta. Mas logo o personagem principal descobre a verdade: todos os membros desta comunidade são clones humanos de 
outras pessoas, com a função de servirem como fornecedores de 'peças de reposição' aos seus proprietários. Lincoln procura fugir deste lugar com uma companheira. Temos várias peripécias, a partir das inevitáveis e espetaculares perseguições encetadas pelas forças do instituto que os havia 'construído'.

Aqui, ainda que no terreno ficcional, é possível trazer, à nossa discussão, aspectos que parecem capazes de redimensionar o estatuto da condição humana dos entes criados a partir das perspectivas potenciais das intervenções genômicas. Assim, seres humanos substituiriam os suínos manipulados geneticamente nos anos 90, com vistas ao xenotransplante. Além disto, são cada vez mais fortes os indícios de que estamos ingressando em um momento crucial em que progenitores passariam a adquirir cada vez mais recursos para determinar o futuro de seus descendentes. Junto a tal poder, surgiriam novas dimensões de responsabilidade genômica.

De qualquer forma, importa destacar que a genômica seria a atividade tecnocientífica paradigmática da tardomodernidade em suas redes e vínculos institucionais, políticos e econômicos. Organiza-se sob os auspícios de uma união da poderosa indústria biotecnológica - representante privilegiada do capital globalizado. Inclui ramos vigorosos de várias disciplinas das ciências biológicas, da biomedicina (em suas vertentes acadêmica e clínico-assistencial) e, também, da epidemiologia. Estes esforços conjuntos costumam se configurar mediante relações entre atores localizados em distintas nações. Envolvem, também, políticos ${ }^{30}$ e gestores preocupados com o aumento dos gastos públicos em relação à saúde e ao bem-estar das populações (Kerr \& Cunningham-Burley, 2000).

Segundo alguns estudiosos do âmbito da economia (Mykitiuk, 2005), a nova genética participa da construção de subjetividades neoliberais que devem dedicar-se responsavelmente à gestão privada de riscos à saúde e também colabora para o desenvolvimento de uma economia fundada em tecnoconhecimentos especialmente voltados para o mercado da assistência à saúde. Do ponto de vista discursivo, a política privatizante também destaca a privacidade, a escolha individual e a autodeterminação. Um de seus eixos retóricos fundamentais consiste em enfatizar ao paroxismo que o formato ideal de organização social é

\footnotetext{
30 Podemos imaginar o presidente dos Estados Unidos e o primeiro-ministro do Reino Unido apadrinhando publicamente um hipotético Atlas mundial sobre desigualdades em saúde? Obviamente não. No entanto, Bill Clinton e Tony Blair não tiveram dúvidas em comparecer para apoiar o desenvolvimento do Projeto Genoma, em junho de 2000, com um alarde high tech sem precedentes. Eram anos em que a bolha de valorização genômica subia e subia de valor. Os políticos dos países mais poderosos do planeta se apressaram, talvez em demasia, em unir sua imagem com a da biotecnologia. Sabem que a opinião pública a identifica com 0 controle sobre a vida. A parafernália midiática deste aparecimento conjunto não ocorre, por exemplo, com a entrega de prêmios Nobel. Este episódio pode ser comparado à infeliz reunião e apresentação de Tony Blair com José María Aznar e George Bush nos Açores, em março de 2003, para anunciar a guerra preventiva contra os iraquianos.
} 
aquele que estabelece como imperativo que os indivíduos autocontrolem suas existências sem a interferência de outrem. Isto deve se dar no interior de interações sociais mescladas a relações econômicas em que impere a descrença na busca de soluções coletivas. Os problemas são individualizados, fora do alcance de alternativas políticas transformadoras.

Nestas contingências, a implementação da agenda globalizada colabora decisivamente para transformação da saúde em uma mercadoria muito dispendiosa, e a assistência à saúde em um negócio privado que envolve investimentos altos e demanda retornos garantidos (Mikitiuk, 2005). Isto, como se sabe, gera uma configuração altamente precarizante em termos de exclusão social e de saúde pública. Sobretudo, se encararmos os contextos dos países ditos periféricos que se debatem em fórmulas para lidar com os ditames econômicos vigentes. E, caso fraquejem, se ajustarem aos programas de ajuste econômico, geralmente geradores de alta instabilidade política e social. Fica difícil crer que, neste tipo de contexto, possa existir um acesso consistente ao mundo da saúde genômica, quando quer que este se descortine. 



\section{ANOTAÇÕES FINAIS}

\section{A Responsabilidade diante dos Limites da Vida}

Neste momento, no âmbito sanitário, para haver alguma possibilidade de participação nas decisões envolvendo ciência, tecnologia, riscos, importa que o maior número possível de pessoas conheçam aspectos e detalhes relativos a estas complexas dimensões. Apesar das evidentes dificuldades, os indivíduos devem participar de processos de aprendizagem que reconheçam as construções leigas existentes. Tal responsabilidade cabe aos profissionais de saúde. Isto traz à cena uma série de questões que demandam encaminhamentos pertinentes.

Por exemplo: quais processos educacionais, tanto em termos didáticos como pedagógicos, seriam capazes de proporcionar elementos significativos para as pessoas nas dimensões de ciência, tecnologia, riscos etc. relacionados às vidas de cada um? Especialmente, se levarmos em conta que os mecanismos educacionais existentes são bastante limitados, sobretudo em termos das populações do chamado terceiro mundo. Como considera Marcelo Leite, exeditor de ciência do jornal Folha de S. Paulo, é bastante reduzida a capacidade das populações brasileiras, em geral, de participar de discussões públicas sobre a pesquisa genômica. Mesmo assim, esse diagnóstico mostra a premência dos agentes envolvidos (incluindo jornalistas científicos e profissionais de saúde) em se dedicarem a apresentar informações acessíveis, inteligiveis e contextualizadas sobre as biotecnologias, em geral, e as testagens genômicas, em particular (Leite, 2002). Isto faz lembrar a história do repórter de jornal que perguntou ao profissional de saúde: '- O que o sr. pode dizer diante do fato de um pesquisador haver descoberto em suas investigações que ratos que inalavam fumaça de cigarro desenvolviam câncer'. Ao que o profissional de saúde responde: '- Isto mostra que mesmo ratos não devem fumar'.

Mas é preciso esclarecer se se trata de responder aos problemas do que se convencionou designar modernidade (ou como se deseje chamar aos tempos atuais: tardo-modernidade, pós-modernidade, supermodernidade, hipermodernidade, segunda modernidade etc.) com respostas que marcaram a fase anterior. Ou seja, mais e melhores: técnica, crescimento econômico, ciência, diferenciações funcionais (Beck, 2000). Ora, tais proposições não mais se sustentam, até porque uma hipótese 'causal' para o estado atual das coisas transita pela percepção da relação de frenesi recursivo entre respostas que participam ativamente das 
perguntas. Como assinala Beck (2000), as transformações políticas e econômicas no planeta puseram em xeque a perspectiva iluminista européia.

No caso das estratégias da gestão de riscos em saúde, por via do estilo de vida ou da genômica, além dos limites da responsabilidade como discurso instituinte de governância, as buscas de solução que clamam por melhores análises técnicas baseadas em ciência estrita não parecem dar conta das muitas dimensões possíveis para pensarmos o que seja a condição humana e as concepções do que é apropriado ou não, 'bom' ou 'mau', mais ou menos arriscado para cada sociedade. Todos estes 'elementos' são constantemente redefinidos e negociados, nem sempre da melhor maneira, já que a própria ciência não traz respostas satisfatórias para estas questões e, por mais que tente, não dá conta das situações de descontrole, incerteza e complexidade que proliferam, como a que rodeia a discussão acerca dos alimentos geneticamente modificados (Finucane \& Holup, 2005).

Lidar com estas controvérsias e conflitos com mais técnica, ciência e globalização econômica até agora não tem obtido os resultados desejáveis. Longe disto, como tentamos descrever em várias circunstâncias ao longo deste livro. Decerto, investigações científicas e estudos técnicos são essenciais para as decisões responsáveis sobre formas de lidar com os riscos, mas formas de ciência que não consideram dimensões vinculadas aos contextos estão fadadas ao fracasso ou então a culpabilizar as vítimas por limitações da própria ciência.

Diante da proliferação hightech que nos acossa, uma pergunta não quer calar. Será que, com os avanços dos conhecimentos tecnocientíficos, epidemiológicos e genômicos, para fazer companhia aos tecnobjetos portáteis que fazem parte de nosso cotidiano (incluindo telefones celulares e suas fusões com câmeras fotográficas e internet, memórias de bolso, palmtops), teremos, algum dia, algum tipo de 'riscômetro' portátil? Mais um novo instrumento 'essencial' para a nossa autogestão que, mimetizando os informes meteorológicos, seria capaz de nos proporcionar constantemente, em nossos palmtops, boletins periódicos e individualizados conforme nossas variáveis relativas à gestão de estilo de vida, a dimensões genéticas e constantes biológicas sumarizadas computadorizadamente, e capaz também de gerar uma previsão contábil constante de nosso risco geral?

Isso ainda parece se situar no âmbito ficcional, mas como nossa época se assemelha cada vez mais a enredos reais de ficção científica, já existem técnicas e pacotes computacionais para a determinação de riscos genéticos (Flodman \& Hodge, 2002). Assim, é possível que, em pouco tempo, talvez, a partir das megainvestigações epidemio-genômicas que estudam o papel dos genes, do ambiente e do estilo de vida nos problemas de saúde, indicados ao início do livro, surgirá algo parecido a riscômetros portáteis - risk-pods. Até porque já existem aqueles que estão disponíveis on-line, como os que aparecem em portais da internet (〈www.youfirst.com〉).

Como o "The minority report", de Dick, em sua proposta pré-cognitiva de prevenção do crime, uma vez mais a ficção científica pode estar sendo premonitória, escrevendo torto, mas por linhas certas. Já existem elementos para configurarem uma prevenção do crime baseada em evidências. 
Rose (2000) aborda os efeitos da nova biologia criminológica nas estratégias de controle do crime que utiliza noções neurobiológicas e genéticas. Em certas áreas do sistema judiciário inglês, há o surgimento de concepções do indivíduo 'geneticamente sob risco' de praticar crimes e o desenvolvimento de estratégias de prevenção baseadas em uma racionalidade de saúde pública. Rose afirma que isto não consistiria em uma nova eugenia, mas uma forma de controle que tenta diagnosticar, tratar e monitorar indivíduos com predisposições a comportamentos violentos, sem limites de autogoverno que seriam próprios do comportamento compativel com as sociedades liberais avançadas. Para controlá-los, seria preciso entender as origens desta conduta para identificar tais indivíduos e intervir de forma a reduzir os riscos de acontecimentos indesejáveis.

Os procedimentos e técnicas para tanto são desenvolvidos em programas de pesquisa em biologia, neurologia, neuroquímica e genética. Estes procuram determinar processos biológicos, marcadores genéticos e fatores de risco para comportamentos violentos e técnicas para identificar os indivíduos sob risco, tais como estudos de adoção, pesquisas endócrinas, estudos de neurofisiologia e estudos de capacidade intelectual, de transtornos de hiperatividade e déficit de atenção, e disfunção cerebral mínima (Rose, 2000).

Neste momento, não importam enunciados quanto à real possibilidade de chegarmos a alguma conclusão a este respeito. Cabe, sim, perceber as orientações e inclinações desta perspectiva. Estes crimes costumam ser encarados em termos moralistas como ações de desajustados, desprovidos de 'autocontrole' que desprezam os laços sociais vigentes e violam os limites em que repousa a responsabilidade moral que rege a conduta de indivíduos livres em uma boa sociedade - liberal. Ou, como exemplos de profunda violência e crueldade de incidem em sociedades periféricas que por supostas limitações próprias (quiçá até genômicas, segundo acadêmicos de responsabilidade ética discutível) não alcançam os patamares de justiça social que lhes permita almejar outros destinos menos trágicos.

Há elementos suficientes para assinalar que a promoção da saúde, seja em termos de estilo de vida, seja em termos genômicos, se tornou um movimento que não lidou satisfatoriamente com os problemas-chave filosóficos no núcleo dos pensamentos políticos de direita e esquerda (consideremos que estas categorias ainda tenham uma sensibilidade epistemológica satisfatória): em explicar a relação do livre arbítrio com o determinismo, nem a concepção de 'boa sociedade', nem do que possa ser a condição humana - quanto se é livre (autônomo) ou se é socialmente determinado? Mas o que é ser livre? Aqui, mais uma vez, se manifestam os problemas de inteligibilidade das categorias disponíveis: o próprio entendimento do que é ser livre pode ser ambíguo nos tempos atuais: livre para se competir e consumir no livre mercado? Livre das injunções econômicas para recusar, sem prejuízos, encaminhamentos em relação a necessidades sociais e poder escolher trajetórias alternativas?

Apesar de suas evidentes limitações, a proposta ensejada pelo exercício crítico da idéia de responsabilidade pessoal enfeixada pela 'sensibilidade epistemológica' tanto do conceito-modelo 'estilo de vida' e das disciplinas genômicas visa a ampliar significados do 
quase sempre restrito debate teórico sobre as propostas de promoção da saúde. Infelizmente, estes enfoques participam da manutenção da iníqua situação de saúde de grandes contingentes populacionais.

Não foi nosso propósito abordar outras dimensões atuais do âmbito da responsabilidade. Mas é importante enfatizar o fato de que, também, é sumamente relevante desenvolver análises e discussões sobre responsabilidades cabíveis a instituições governamentais em seus múltiplos níveis de atuação em termos de políticas públicas e suas respectivas capacidade de atender necessidades e demandas em saúde das populações, tanto em termos nacionais como internacionais.

Da mesma forma, é preciso delimitar as responsabilidades da iniciativa privada. Ao seguirem as receitas da otimização econômica no interior dos fluxos da dinâmica globalizada, as empresas transnacionais, conforme suas conveniências contábeis, desfrutam de incentivos e favorecimentos propiciados pelos locais em que se instalam. Se esta balança se desequilibra, deslocam-se para outros lugares cujas vantagens sejam mais atraentes. Dentro deste panorama descrito de modo bastante simplificado, a dimensão das responsabilidades em saúde tende a escapar de tentativas de pressão e regulação por parte de governos, quando não encontram algum tipo de vantagem ou benefício. Sem dúvida, essas são questões de suma importância para o terreno da saúde pública.

Aqui, importa considerar ainda que há que se enfrentar na atualidade a acentuada ênfase conservadora que se alicerça na perspectiva econômica liberal na qual a responsabilidade seria algo estritamente vinculado ao terreno das ações humanas desenvolvidas por indivíduos especificados e definidos. E não na esfera pública e, portanto política, esfumando-se, assim, a responsabilidade com o coletivo (Cruz, 2005).

Enfim, independentemente da pertinência, vários dos textos aqui discutidos parecem apenas dirigir-se ao contexto das democracias liberais avançadas e soam tristemente distantes de outros contextos político-econômicos (quando há menção a estas outras regiões, sintomaticamente, é usual utilizar-se o adjetivo 'global' - como em 'bioética global' ou 'epidemiologia global'). Talvez justamente por estas razões, seja possível analisá-los do ponto de vista da 'governamentalidade' e perceber que, ao lado das preocupações de ordem distributiva, são perceptíveis os elementos de tecnologia política e moral e de seus valores individualistas nos cenários futuros de ordenação sociocultural. Isto aparece nas reiteradas menções ao direito de decidir após serem devidamente informados (pelas evidências disponíveis). Permanecemos no onipresente eixo de gestão individual e racional das questões de saúde.

É preciso dimensionar quais serão, por um lado, os custos e a resolutividade das intervenções genômicas em termos de efeitos débeis em relação a doenças crônico-degenerativas, e, por outro, procurar delinear as possíveis repercussões éticas, legais, sociais relativas a questões de acesso eugenômico, se este for desejável. E também chamar, sempre que possível, a atenção dos países economicamente mais fortes quanto à insuficiência de discursos e das ações de promoção da saúde baseadas no ambíguo conceito estilo de vida, sob a perspec- 
tiva potencialmente ampliadora da distância entre pobres e ricos. Tais perspectivas, para além dos limites da responsabilidade, excluem cerca de três quartos da população planetária da repartição de benefícios provenientes da aplicação dos conhecimentos em saúde. E, além do mais, ainda correm o risco de serem responsabilizados por tais mazelas.

Mesmo assim, ainda é preciso salientar que quando a política se torna biopolítica e toma a saúde e, por extensão, a vida como objeto de intervenção preventiva total, priva-a de sua dimensão de abertura, restringindo-a ao ditame do privilégio à longevidade biológica. Os mecanismos de proteção e preservação da saúde passam consistir na negação da vida e na sustentação da sobrevida. Trazendo o filósofo político italiano Roberto Esposito (2005) para o contexto da saúde, preservar a vida significa transitar pela lógica imunitária - a busca compulsiva por 'imunidade', de modo a afastar os riscos à saúde que podem nos afetar e nos vitimar.

Para viver muito tempo, é imprescindivel a vigilância extensiva e normalizadora que acaba impedindo a possibilidade de transcendência. Viver sob a égide biopolítica é perpetuar a vida através do sacrifício existencial do ser vivente, reduzindo-o ao âmbito biológico. Na saúde persecutória, vive-se sob o primado paradoxal da sentença e da condenação culposa sem delito como estratégia de afastamento dos riscos à sobrevida, que, para ser mantida sob esta forma, passa a ser achatada aos limites somáticos ao preço da negação do mais humano que há na vida. 



\section{REFERENNCIAS}

AGAMBEN, G. Homo Sacer: poder soberano e vida nua. Belo Horizonte: UFMG, 2002.

AGAMBEN, G. Profanaciones. Barcelona: Anagrama, 2005.

ALMEIDA-FILHO, N. La Ciencia Tímida: ensayos de deconstrucción de la epidemiología. Buenos Aires: Lugar Editorial, 2000.

ARENDT, H. A Condição Humana [1958]. São Paulo: Forense Universitária, 1995.

ARENDT, H. Responsibility and Judgment. Nova York: Schocken Books, 2003.

BALANDIER, G. O Dédalo: para finalizar o século XX. Rio de Janeiro: Bertrand Brasil, 1999.

BACKETT, K. \& DAVISON, C. Lifecourse and lifestyle: the social and cultural location of health behaviours. Social Science and Medicine, 40: 629-638, 1995.

BAUMAN, Z. Liquid Love: on the frailty of human bonds. Londres: Polity Press, 2003.

BAUMAN, Z. Vidas Desperdiciadas: la modernidad y sus parias. Barcelona: Paidós, 2005.

BEATTIE, A. Knowledge and control in health promotion: a test case for social policy and social theory. In: GABE J., CALNAN, M. \& BURY, M. (Eds.) The Sociology of the Health Service. Londres: Routledge, 1991, p. 162-202.

BEAUFORT, I. Whose lifestyle is it anyway? In: BEAUFORT, I. D. \& HILHORST, M. T. (Eds.) Individual Responsibility for Health: moral issues regarding lifestyles. Bruxelas: European Commission, 1996.

BECK, U. Un Nuevo Mundo Feliz: la precariedad del trabajo en la era de la globalización. Madri: Paidós, 2000.

BELLIS, M. A; HUGHES, K. \& ASHTON, J. R. The promiscuous 10\%. Journal of Epidemiology and Community Health, 58: 889-890, 2004.

BELLIS, M. A. et al. Measuring paternal discrepancy and its public health consequences. Journal of Epidemiology and Community Health, 59: 749-754, 2005.

BOURDIEU, P. O Poder Simbólico. Lisboa: Difel, 1989.

BORGES, J. L. A biblioteca de Babel. In: BORGES, J. L. A Biblioteca de Babel: ficções. Porto Alegre: Globo, 1972a. 
BORGES, J. L. Pierre Menard, autor de Quixote. In: BORGES, J. L. A Biblioteca de Babel: ficções. Porto Alegre: Globo, 1972b.

BORGES, J. L. O idioma analítico de John Wilkins. In: BORGES, J. L. Obras Completas. São Paulo: Ed. Globo, 1999. v.II.

BOYNE, R. Post panopticism. Economy and Society, 29: 285-307, 2000.

BREILH, J. Epidemiologia Crítica: ciencia emancipatoria e interculturalidad. Buenos Aires: Lugar Editorial, 2003.

BRITISH MEDICAL ASSOCIATION. Human Genetics: choice and responsibility. Oxford: Oxford University Press, 1998.

BRUNDTLAND, G. H. Foreword form the director general. In: World Health Organization. Genomics and World Health. Report of the advisory committee on health research, Geneva: WHO, 2002, p. 13-14. Disponivel em: 〈www.whqlibdoc.who.int/hq/2002/a74580.pdf〉. Acesso em: 3 maio. 2005.

BUnton, R.; NetTleton, S. \& BURROWS, R. (Eds.) The Sociology of Health Promotion: critical analyses of consumption, lifestyle and risk. Nova York: Routledge, 1995.

BURNHAM, T. \& PHELAN, J. A Culpa é da Genética. Rio de Janeiro: Sextante, 2002.

CASTIEL, L. D. A Medida do Possivel... Saúde, Risco e Tecnobiociências. Rio de Janeiro: Fiocruz, 1999.

CASTIEL, L. D. Genes perversos. Folha de S. Paulo, Suplemento Mais!, 564: 20-21, 2002.

CASTIEL, L. D. \& VASCONCELLOS-SILVA, P. R. Don Quixotech in New Laputa. Journal of Epidemiology $\mathbb{E}$ Community Health, 61: 388, 2007.

CARVALHO, S. R. As contradições da promoção à saúde em relação à produção de sujeitos e à mudança social. Ciência e Saúde Coletiva, 9(3): 669-678, 2004.

CHEN, M-Y. et al. Adolescent health promotion scale: development and psychometric testing. Public Health Nursing, 20(2): 104-110, 2003.

CHOKSHI, D. A. \& KWIATOWSKI, D. P. Ethical challenges of genomic epidemiology in developing countries. Genomics, Society and Policy, 1(1): 1-15, 2005.

COCKERHAM, W. C.; RUTTEN, A. \& ABEL, T. Conceptualizing contemporary health lifestyles: moving beyond Weber. The Sociological Quarterly, 38: 321-342, 1997.

COHEN, J. The genomics gamble. Science, 275: 767-776, 1997.

COHEN, A. M.; STAVRI, P. Z. \& HERSH, W. R. A categorization and analysis of the criticisms of evidence-based medicine. International Journal of Medical Informatics, 73(1): 35. 43, 2004.

COORS, M. E. A foucauldian foray into the new genetics. Journal of Medical Humanities, 24(3/ 4): 279-289, 2003.

COVENEY, J. The government and ethics of health promotion: the importance of Michel Foucault. Health Education Research - Theory \& Practice, 13(3): 459-468, 1998. 
CRAWFORD, R. You are dangerous to your health: the ideology and politics of victim blaming. International Journal of Health Services, 7: 663-680, 1977.

CRISTIANO, J. L. El 'imperio de nadie': sobre autoría y responsabilidad. Revista Anthropos Huellas del Conocimiento, 206: 184-196, 2005.

CRUZ, M. Las Malas Pasadas del Pasado: identidad, responsabilidad, historia. Barcelona: Anagrama, 2005.

DAVEY-SMITH, G. Genetic epidemiology: an 'enlightened narrative'. International Journal of Epidemiology, 33:923-924, 2004.

DICK, P. K. The minority report. In: DICK, P. K. The Collected Stories of Philip K. Dick. Nova York: Carol Publishing Group, 1991. v.4.

DICK, P. K. Introduction. Do Androids Dream of Electric Sheep? Nova York: Harper-Collins, 1996. (Voyager series)

DIEZ-ROUX, A. V. A glossary for multilevel analysis. Journal of Epidemiology E̊ Community Health, 56: 588-594, 2002.

DODDS, C. Messages of responsibility: HIV/Aids prevention materials in England. Health, 6(2): 139-171, 2002.

DONINI, L. M. et al. Orthorexia nervosa: a preliminary study with a proposal for diagnosis and an attempt to measure the dimension of the phenomenon. Eat Weight Disord, 9(2):151. 157, jun., 2004.

DOUGLAS, M. Risk and Blame: essays in cultural theory. Londres: Routledge, 1992.

DWORKIN, G. Voluntary health risks and public policy. Hastings Center Report, 11(5): 26-31, 1981.

EDWARDS, P. Rethinking lifestyle... From a social determinants of health perspective. Disponível em: 〈www.aldergroup.com/pdf/rethinking_lifestyle.pdf〉. Acesso em: 28 mar. 2005.

ERIKSSON, M. \& LINDSTRÖM, B. Validity of Antonovsky's sense of coherence scale: a systematic review. Journal of Epidemiology and Community Health, 59: 460-466, 2005.

ESTADOS UNIDOS. Center for Disease Control and Prevention. Health Risks in the United States: behavioral risk factor surveillance system 2003. Disponível em: <www.cdc.gov/nccdphp/ aag/aag_brfss.htm>. Acesso em: 25 nov. 2005.

FEATHERSTONE, M. Cultura de Consumo e Pós-Modernismo. São Paulo: Studio Nobel, 1995.

FINUCANE, M. L. \& HOLUP, J. L. Psychosocial and cultural factors affecting the perceived risk of genetically modified food: an overview of the literature. Social Science $\mathcal{B}$ Medicine, 60: 1603-1612, 2005.

FITZPATRICK, M. The Tiranny of Health: doctors and the regulation of lifestyle. Londres: Routledge, Taylor and Francis, 2001. 
FLECK, L. M. Is responsible eugenics disingenuous ethics? Newsletter on Philosophy and Medicine, 99(1), 1999.

FLODMAN, P. \& HODGE, S. E. Determining complex genetic risks by computer. Journal of Genetic Counseling, 11(3): 213-230, 2002.

FOUCAULT, M. Technologies of the self. In: MARTIN, L. H. (Ed.) Technologies of the Self: a seminar with Michel Foucault. Londres: Tavistock, 1988.

FOUCAULT, M. História da Sexualidade 2: o uso dos prazeres. Rio de Janeiro: Graal, 1984a.

FOUCAULT, M. História da Sexualidade 3: o cuidado de si. Rio de Janeiro: Graal, 1984b.

FOUCAUlT, M. As Palavras e as Coisas. São Paulo: Martins Fontes, 1992.

FRANKISH, C. J.; MILLIGAN, C. D. \& REID, C. A review of relationships between active living and determinants of health. Social Science and Medicine, 47(3):287-301, 1998.

FRENCH, D. P. et al. Causal attributions for heart disease: a systematic review. Psychology $\mathcal{E}$ Health, 16: 77-98, 2001.

FRENCH, D. P.; MAISSI, E. \& MARTEAU, T. M. The purpose of attributing cause: beliefs about the causes of myocardial infarction. Social Science $\mathcal{E}$ Medicine, 60: 1411-1421, 2005.

FRESNILLO-NÚÑ̃EZ, J. Comunicação pessoal, 2005.

FROHLICH, K. L.; CORIN, E. \& POTVIN, L. A theoretical proposal for the relationship between context and disease. Sociology of Health and Illness, 23(6): 776-797, 2001.

FROHLICH, K. L. et al. A theoretical and empirical analysis of context: neighbourhoods, smoking and youth. Social Science and Medicine, 54: 1401-1417, 2002.

GALVIN, R. Disturbing notions of chronic illness and individual responsibility: towards a genealogy of morals. Health, 6(2): 107-137, 2002.

GAVIN, J. Pairing personality with activity new tools for inspiring active lifestyles. The Physician and Sportsmedicine, 32(12), 2004. Disponível em: <www.physsportsmed.com.issues/2004/1204/gavin.htm〉. Acesso em: 28 mar. 2005.

GIDDENS, A. Central Problems in Social Theory: activity, structure and contradiction in social analysis. Londres: Macmillan, 1979.

GIDDENS, A. Runaway World: how globalization is reshaping our lives. Londres: Routledge, 2000.

GIDDENS, A. A Modernity and Self-Identity: self and society in the late modern age. Cambridge: Polity Press, 2002.

GINZBURG, C. Olhos de Madeira: nove reflexões sobre a distância. São Paulo: Companhia das Letras, 2004.

GORI, R. \& DEL VOLGO, M-J. La Santé Totalitaire: essai sur la médicalisation de l'existence. Paris: Denoel, 2005.

GUTTMAN, N. \& RESSLER, W. H. On being responsible: ethical issues in appeals to personal responsibility in health campaigns. Journal of Health Communication, 6: 117-136, 2001. 
HALLYDAY, J. et al. Genetics and public health - evolution, or revolution? Journal of Epidemiology and Community Health, 58(11): 894-899, 2004.

HALPERN, D. et al. Personal Responsibility and Changing Behaviour: the state of knowledge and its implications for public policy. Londres: Cabinet Office Prime Minister Strategy Unit, 2004.

HÉLLER, A. \& FÉHER, F. Biopolítica: la modernidad y la liberación del cuerpo. Barcelona: Península, 1995.

HOUAISS, A. \& VILlAR, M. S. Dicionário Houaiss da Lingua Portuguesa. Rio de Janeiro: Objetiva, 2001.

HOFMAN, K. J.; ANAND, N. P. \& KEUSCH, G. T. Bridging the health genomics divide: a case for building research capapcity in the south. In: KNOPPERS, B. M. \& SCRIVER, C. (Eds.) Genomics, Health and Society: emerging issues for public policy. Policy Research Initiative publ., 143-154, 2004.

HUGHES, B. Health promotion and moral self-management in everyday life. Disponivel em: <www.mngt.waikato.ac.nz/ejrot/cmsconference/documents/Management\% 20 Everyday/HealthPromotionandmoralSelf.pdf>. Acesso em: 24 jan. 2005.

HUMAN GENETICS COMMISSION. Inside Information. Balancing interests in the use of personal genetic data. A summary report by the Human Genetics Commission, 2002. Disponível em: <www.hgc.gov.uk/UploadDocs/DocPub/Document/ insideinformation_summary.pdf $\rangle$. Acesso em: 5 maio 2005.

ILLICH, I. Health as one's own responsibility - No, thank you! Disponível em: 〈www.homepage.mac.com/tinapple/illich/1990_health_responsibility.PDF〉. Acesso em: 1 mar. 2005.

ILLICH, I. Medical Nemesis: the expropriation of health. Londres: Marian Boyars, 1975.

INNERARITY, D. La Sociedad Invisible. Madri: Espasa Calpe, 2004.

KAUFERT, P. A. Health policy and the new genetics. Social Science and Medicine, 51: 821-829, 2000.

KENEN, R. H. The at-risk health status and technology: a diagnostic invitation and the "gift" of knowing. Social Science and Medicine, 42(11): 1545-1553, 1996.

KERR, A. \& CUNNINGHAM-BURLEY, S. On ambivalence and risk: reflexive modernity and the new human genetics. Sociology, 34(2): 283-304, 2000.

KEVLES, D. V. Out of eugenics: the historical politics of the human genome. In: KEVLES, D. J. \& HOOD, L. (Eds.) The Code of Codes: scientific and social issues in the human genome project. Cambridge: Harvard Univestity Press, 1992.

KHOURY, M. J. et al. The emergence of epidemiology in the genomics age. International Journal of Epidemiology, 33: 936-944, 2004.

KIM, S. et al. A cross-national comparison of lifestyle between China and the United States, using a comprehensive cross- national measurement tool of the healthfulness of lifestyles: the Lifestyle Index. Preventive Medicine, 38: 160-171, 2004. 
KITCHER, P. Lives to Come: the genetic revolution and human possibilities. Nova York: Free Press, 1997.

KNOPPERS, B. M. \& SCRIVER, C. (Eds.) Genomics, Health and Society: emerging issues for public policy. Policy Research Initiative publ., 2004.

KNOWLES, J. H. The responsibility of the individual. Daedalus, 57-80, 1977.

KOCH, L. \& SVENDSEN, M. N. Providing solutions-defining problems: the imperative of disease prevention in genetic counseling. Social Science $\mathcal{E}$ Medicine, 60: 823-832, 2005.

KONRAD, M. Predictive genetic testing and the making of the pre-symptomatic person: prognostic moralities amongst Huntington's-affected families. Anthropology $\mathbb{E}$ Medicine, 10(1): 23-49, 2003.

LABERGE, C. Health, genome and society. In: KNOPPERS, B. M. \& SCRIVER, C. (Eds.) Genomics, Health and Society: emerging issues for public policy. Policy Research Initiative publ., 2004.

LAST, J. M. (Ed.). A Dictionary of Epidemiology. Nova York: Oxford University Press, 1989.

LAURITZEN, S. O. \& SACHS, L. Normality, risk and the future. Implicit communication of threat in health surveillance. Sociology of Health and Illness, 23(4): 497-516, 2001.

LAW, J. After Method: mess in social science research. Londres: Routledge, 2004.

LAWRENCE, R. Framing obesity: the evolution of news discourse on a public health issue. Press/Politics, 9(3): 56-75, 2004.

LEITE, M. As biotecnologias e suas quimeras. In: BRASIL. Ministério de Ciência e Tecnologia. Ética das Manipulações Genéticas: proposta para um código de conduta. Edição especial de Parcerias Estratégicas, publicação do Centro de Gestão e Estudos Estratégicos, 2002, p. 213-221.

LEMKE, T. The birth of Bio-politics - Michel Foucault's lecture at the Collège de France on neo-liberal governmentality. Economy and Society, 30(2): 190-207, 2001.

LEMKE, T. Foucault, governmentality and critique. In: Rethinking Marxism, 14. Jg., n. 3, S. 49. 64S. 49-64, 2002.

LEMKE, T. Disposition and determinism - genetic diagnostics in risk society. Disponível em: 〈www.thomaslemkeweb.de〉. Acesso em: 1 abr. 2005, 2005a.

LEMKE, T. Genetic testing, eugenics and risk. Disponível em: 〈www.thomaslemkeweb.de〉. Acesso em: 1 abr. 2005, 2005b.

LEVENE, S. Genetic screening in the ashkenazi jewish population - is there a case for more testing? A report for the National Screening Committee on the meeting held on 3rd June 2004 at Guy's Hospital. Disponível em: <www.cmgp.org.uk/resources/pdf/ nsc_report.pdf>. Acesso em: 1 abr. 2005.

LEVIN, T. Y.; FROHNE, U. \& WEIBEL, P. CTRL [SPACE]: rhetorics of surveillance from Bentham to Big Brother. Boston: MIT Press, 2002. 
LI, Y-F. et al. Maternal and grandmaternal smoking patterns are associated with early childhood asthma. Chest, 127: 1232-1241, 2005.

LIPKIN, M. \& ROWLEY, P. T. (Eds.) Genetic Responsibility: on choosing our children genes. Nova York: Plenum Press, 1974.

LUPTON, D. The Imperative of Health: public health and the regulated body. Londres: Sage Publ., 1995.

LYON, D. An electronic panopticon? A sociological critique of surveillance theory. The Sociological Review, 41: 653-678, 1993.

MARTIN, M. W. Responsibility for health and blaming victims Journal of Medical Humanities, 22(2):95-114, 2001.

MARTIN-LLAGUNO, M. \& ALVAREZ-DARDET, C. The genome alibi project: towards a genetic reductionism? Journal of Epidemiology and Community Health, 54: 641, 2000.

MARTINEZ-GONZALEZ, M. A. \& DE IRALA, J. Medicina preventiva y fracaso clamoroso de la salud pública: llegamos mal porque llegamos tarde. Medicina Clinica, 124(17): 656-660.

MERLO, J. et al. A brief conceptual tutorial of multilevel analysis in social epidemiology: linking the statistical concept of clustering to the idea of contextual phenomenon'. Journal of Epidemiology \& Community Health, 59: 443-449.

MERLO, J. et al. A brief conceptual tutorial on multilevel analysis in social epidemiology: investigating contextual phenomena in different groups of people. Journal of Epidemiology E Community Health, 59: 729-736.

MERTON, R. Ciencia, Tecnología y Sociedad en la Inglaterra del Siglo XVII [1938]. Madri: Alianza Editorial, 1984.

MYKITIUK, R. The new genetics in the postkeynesian state. Disponível em: <www.cwhn.ca/ groups/biotech/availdocs/15-mykitiuk.pdf>. Acesso em: 25 jan. 2005.

MINKLER, M. Personal responsibility for health? A review of the arguments and the evidence at century's end. Health Education and Behavior, 26(1): 121-140, 1999.

MONK, H. M. et al. A simple way to measure daily lifestyle regularity. Journal of Sleep Research, 11: 183-190, 2002.

NATHANSON, C. A. Social movements as catalysts for policy change: the case of smoking and guns. Journal of Health Politics and Law, 24(3):421-488, 1999.

NOVAS, C. \& ROSE, N. Genetic risk and the birth of the somatic individual. Economy and Society, 29(4): 485-513, 2000.

NUFFIELD COUNCIL ON BIOETHICS. Genetics and human behaviour: the ethical context. Nuffield Foundation, Wellcome Trust \& Medical Research Council. Disponível em: 〈www.nuffieldfoundation.org/bioethics〉. Acesso em: 3 nov. 2003.

ORTEGA, F. Práticas de ascese corporal e construção de bioidentidades. Cadernos de Saúde Coletiva, 11(1): 59-77, 2003.

ORTEGA, F. Biopolíticas de saúde: reflexões a partir de Michel Foucault, Agnes Heller e Hannah Arendt. Interface - Comunicação, Saúde, Educação, 8(14): 9-20, 2003/2004. 
PALMER, L. J. The new epidemiology: putting the pieces together in complex disease aetiology. International Journal of Epidemiology, 33:925-928, 2004.

PETERSEN, A. \& LUPTON, D. The New Public Health: health and self in the age of risk. Londres: Sage Publications, 1996.

PETERSEN, A. \& BUNTON, R. (Eds.) Foucault, Health and Medicine. Londres: Routledge, 1997.

PETERSEN, A. \& BUNTON, R. The New Genetics and the Public's Health. Londres: Routledge, 2002.

PETERSEN, A. Genetic citizenship: acting 'responsibly in the age of biotechnology', Conference: Vital Politics: Health, Medicine and Bioeconomics into the Twenty-First Century, London School of Economics, $5-7$ sep., 2003. Disponível em: www.lse.ac.uk/collections/ BIOS/docs/AlanPetersen.pdf. Acesso em: 03 maio 2005.

PICKETT, K. E. \& PEARL, M. Multilevel analysis of neighbourhood socioeconomic context and health outcomes: a critical review. Journal of Epidemiology and Community Health, 2001.

PRIOR, L. Rationing through risk assessment in clinical genetics: all categories have heels. Sociology of Health and Illness, 23(5): 570-593, 2001.

REITH, G. Uncertain times. The notion of 'risk' and the development of modernity. Time EZ Society, 13(2/3): 383-402, 2004.

RIPPE, J. M. (Org.) Lifestyle Medicine. Nova York: Blackwell Publishers, 1999.

ROBERTSON, A. Biotechnology, political rationality and discourses on health. Health 5(3): 293-309, 2001.

ROPEIK, D. \& GRAY, G. Risk: a practical guide for deciding what's really safe and what's really dangerous in the world around you. Boston: Houghton Mifflin.

ROSE, N. The biology of culpability: pathological identity and crime control in a biological culture. Theoretical Criminology, 4(1): 5-34, 2000.

RYAN, W. Blaming the Victim. Nova York: Random House, 1976.

SACHS, L. Causality, responsibility and blame - core issues in the cultural construction and subtext of prevention. Sociology of Health $\mathcal{E}$ Illness, 18(5): 632-652, 1996.

SCOTT, S. et al. Repositioning the patient: the implications of being 'at risk'. Social Science E Medicine, 60: 1869-1879, 2005.

SCRIVER, C. Foreword. In: KNOPPERS, B. M. \& SCRIVER, C. (Eds.) Genomics, Health and Society: emerging issues for public policy. Policy Research Initiative publ., 2004.

SEARLE, J. A Redescoberta da Mente. São Paulo: Martins Fontes, 1997.

SEEDHOUSE, D. Health Promotion: philosophy, prejudice and practice. Nova York: John Wiley and Sons, 1997.

SEN, A. Missing women-revisited. British Medical Journal, 327: 1297-1298, 2003.

SERRES, M. Hominescences. Paris: Le Pommier, 2001. 
SKRABANEK, P. The Death of Humane Medicine and the Rise of Coercive Healthism. Bury St Edmunds: Social Affairs Unit, St Edmundsbury Press, 1994.

SOFFER, J. Blame and ethics (Derrida and deconstruction). Disponível em: <www.home.uron.cc/joshsoffer/afterdeconstruction/deconstruction.html\#saa〉. Acesso em: 11 fev. 2005.

SOUSA-SANTOS, B. Pela Mão de Alice: o social e o político na pós-modernidade. São Paulo: Cortez, 1995.

SWIFT, J. Gulliver's Travels. Londres: Penguin Books, 2001.

TROCCHIO, F. di. Las Mentiras de la Ciencia.iPor Qué y Cómo Engañan los Científicos? Madri: Alianza Editorial, 1995.

VALVERDE, J. B. Subjetividade e poder. Disponível em: <www.usuarios.cultura.com.br/ valverde/poder.htm>. Acesso em: 17 fev. 2005.

VAN DE VATHORST, S. \& ALVAREZ-DARDET, C. Doctors as judges: the verdict on responsibility for health. Journal of Epidemiology and Community Health, 54: 162-164, 2000.

WEBER, M. Ecomomy and Society: an outline of interpretative sociology. Berkeley: University of California Press, 1978.

WILLIS, E. Public health and genetics: challenges for the social sciences. Disponivel em: <www.ssn.flinders.edu.au/soci/staff/riaz/genomeproject/4.htm〉. Acesso em: 15 fev. 2005.

WINNETT, R. \& PORTER, A. Toddler tearaways targeted. Disponível em: <www.timesonline.co.uk/article/0,2087-1650919,00.html〉. Acesso em: 13 jun. 2005.

WHO. World Health Organization. Health Promotion Glossary. Genebra: WHO/HPR/HEP/ 98.1, 1998.

WHO. World Health Organization. Genomics and world health. Report of the advisory committee on health research. Genebra: WHO, 2002. Disponível em: <www.whqlibdoc.who.int/hq/2002/a74580.pdf〉. Acesso em: 3 maio. 2005.

\section{PORTAIS E PÁGINAS DE INTERNET}

<www.assineabril.com/index.html?destino=malhoestilo\&origem $=$ sr $/$ estilo $>$. Acesso em: 19 nov. 2004.

<www.blackwellpublishing.com/book.asp?ref=086542294X\&site=1〉. Acesso em: 19 nov. 2004 . <www.cdc.gov/nccdphp/aag/aag_brfss.htm>. Acesso em: 25 nov. 2004.

<www.espacioexterior.net/dickdcho.html〉. Acesso em: 1 fev. 2005.

<www.evasanagustin.com/addb/2004/nobel2004>. Acesso em: 15 abr. 2005.

〈www.genzymegenetics.com/patient/conditions/gene_p_patient_conditions_AJ.asp〉. Acesso em: 1 abr. 2005.

<www.hometown.aol.com/zbic/life/>. Acesso em: 17 mar. 2005. 
〈www.orthorexia.com〉. Acesso em: 15 mar. 2005.

〈www.philipkdick.com/aa_biography.html〉. Acesso em: 1 fev. 2005.

〈www.ravnskov.nu/cholesterol.htm〉. Acesso em: 18 mar. 2005.

<www.rippelifestyle.com/index.shtml>. Acesso em: 27 nov. 2004.

<www.rippelifestyle.com/newscontent/newsstory.shtml〉. Acesso em: 27 nov. 2004.

〈www.thincs.org〉. Acesso em: 18 mar. 2005.

$<$ www.ultralingua.net/index.html?action $=$ define $\&$ sub $=1 \&$ searchtype=stem med \& te $\mathrm{xt}=$ sacer\&service=latin2english>. Acesso em: 28 mar. 2005.

<www.youfirst.com〉. Acesso em: 14 nov. 2004. 

Formato: $16 \times 23 \mathrm{~cm}$

Tipologia: Goudy Old Style e New Gothic Cn

Papel: Polén Bold $70 \mathrm{~g} / \mathrm{m}^{2}$

Cartão Supremo $250 \mathrm{~g} / \mathrm{m}^{2}$

Fotolitos: Engenho \& Arte Gráfica Ltda. (capa e miolo)

Impressão e acabamento: Imprinta Express Gráfica e Editora Ltda.

Rio de Janeiro, junho de 2007.

Não encontrando nossos títulos em livrarias contactar a EDITORA FIOCRUZ:

Av. Brasil, 4036 - $1^{\circ}$ andar - sala 112 - Manguinhos

21040-361 - Rio de Janeiro - RJ

Tel.: (21) 3882-9039 e $3882-9041$

Telefax: (21) 3882-9006

http://www.fiocruz.br/editora

e-mail: editora@fiocruz.br 